Prepared in cooperation with the Papio-Missouri River Natural Resources District

\title{
Altitude, Age, and Quality of Groundwater, Papio-Missouri River Natural Resources District, Eastern Nebraska, 1992 to 2009 \\ SOUTH
}

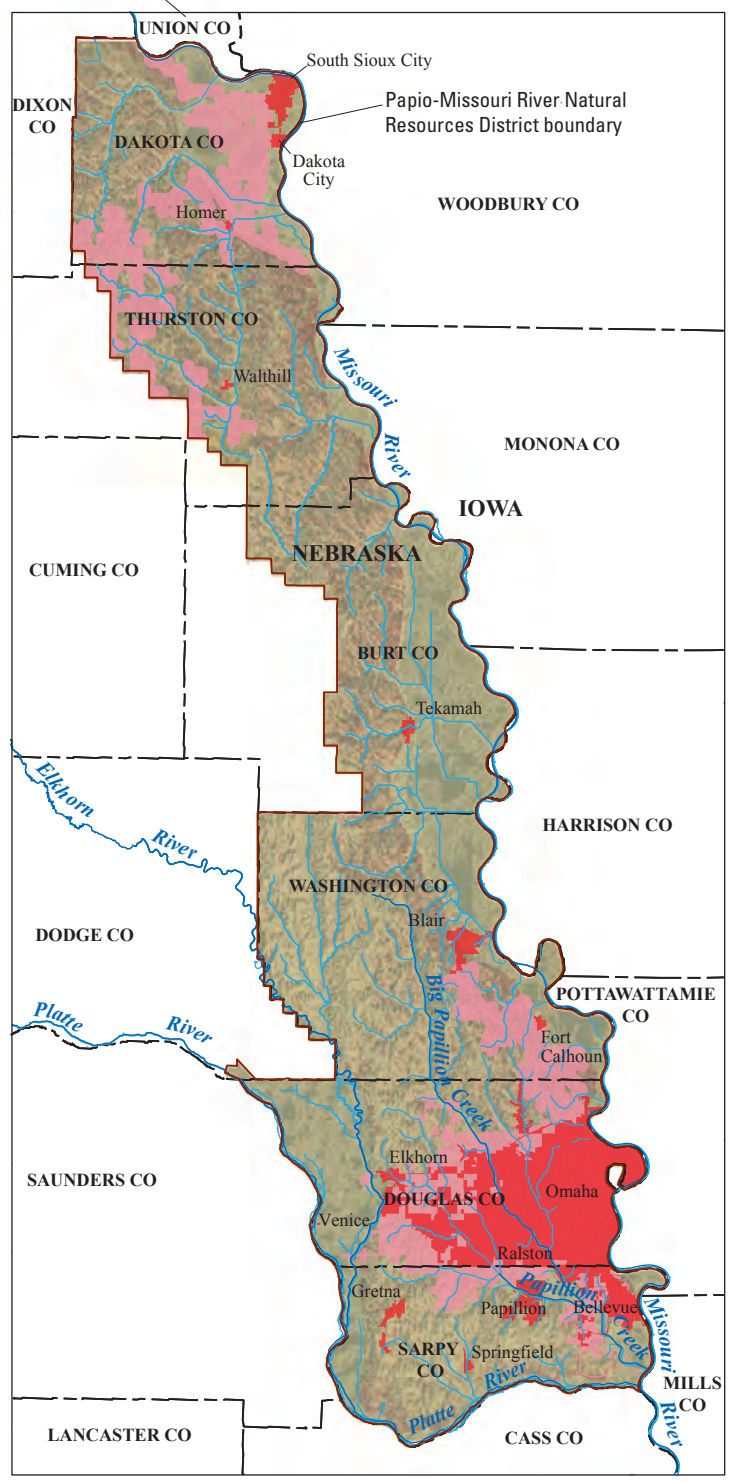

Scientific Investigations Report 2012-5036 
Cover. Figure 1 from the report with modifications. 


\section{Altitude, Age, and Quality of Groundwater, Papio-Missouri River Natural Resources District, Eastern Nebraska, 1992 to 2009}

By Virginia L. McGuire, Derek W. Ryter, and Amanda S. Flynn

Prepared in cooperation with the Papio-Missouri River Natural Resources District

Scientific Investigations Report 2012-5036 


\title{
U.S. Department of the Interior \\ KEN SALAZAR, Secretary \\ U.S. Geological Survey \\ Marcia K. McNutt, Director
}

\author{
U.S. Geological Survey, Reston, Virginia: 2012
}

For more information on the USGS - the Federal source for science about the Earth, its natural and living resources, natural hazards, and the environment, visit http://www.usgs.gov or call 1-888-ASK-USGS.

For an overview of USGS information products, including maps, imagery, and publications, visit http://www.usgs.gov/pubprod

To order other USGS information products, visit http://store.usgs.gov

Any use of trade, product, or firm names is for descriptive purposes only and does not imply endorsement by the U.S. Government.

Although this report is in the public domain, permission must be secured from the individual copyright owners to reproduce any copyrighted materials contained within this report.

Suggested citation:

McGuire, V.L., Ryter, D.W., and Flynn, A.S., 2012, Altitude, age, and quality of groundwater, Papio-Missouri River Natural Resources District, eastern Nebraska, 1992 to 2009: U.S. Geological Survey Scientific Investigations Report 2012-5036; 68 p., available on the Web at http://pubs.usgs.gov/sir/2012/5036. 


\section{Contents}

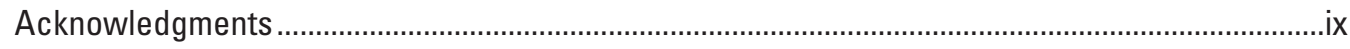

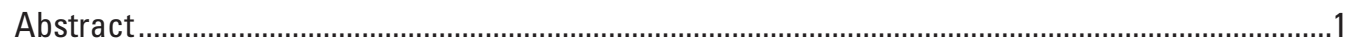

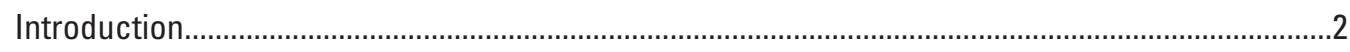

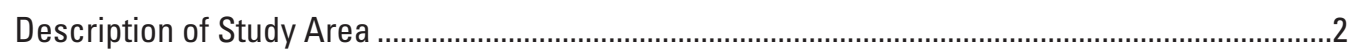

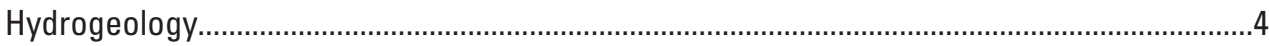

Hydrogeologic Units in Surficial Deposits ..................................................................

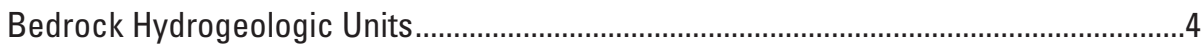

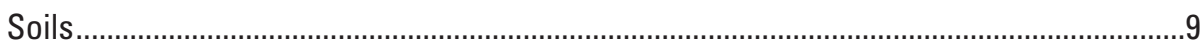

Land and Water Use ...................................................................................................

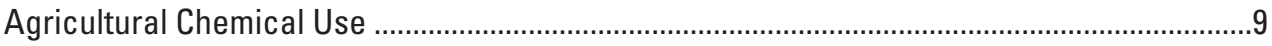

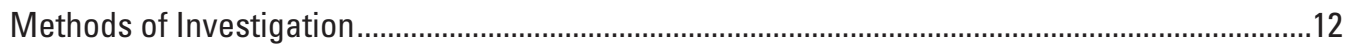

Well Nest Installation, 1999.................................................................................................12

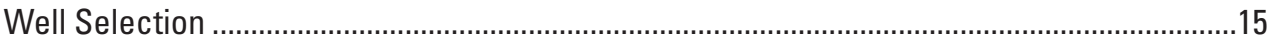

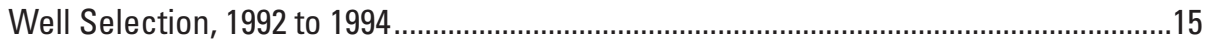

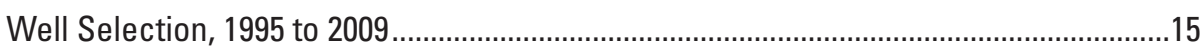

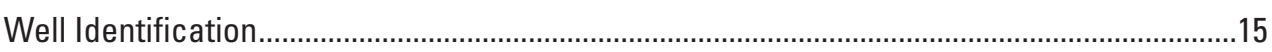

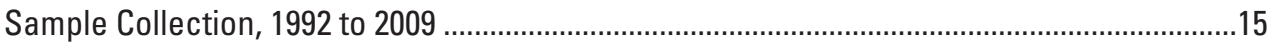

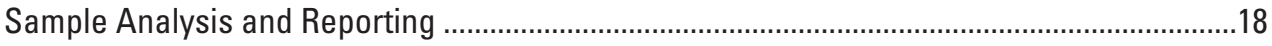

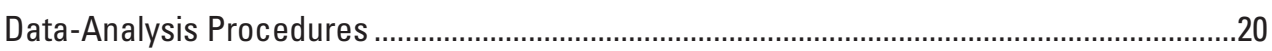

Construction of Water-Table and Potentiometric-Surface Maps...................................20

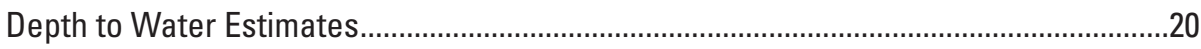

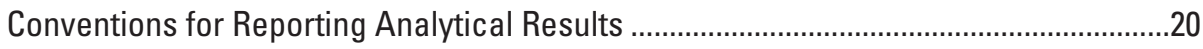

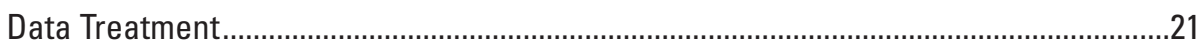

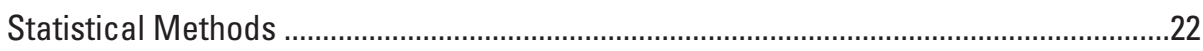

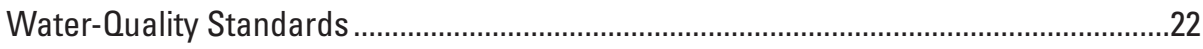

Age Dating of Groundwater Using Chlorofluorocarbons ................................................24

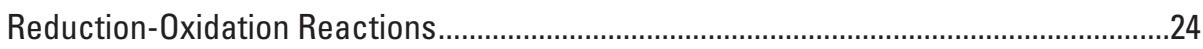

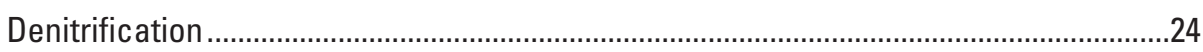

Quality Assurance and Quality Control ............................................................................2

Field-Blank, Equipment-Blank, and Source-Solution Blank Samples..............................25

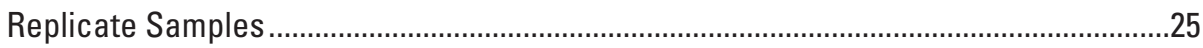

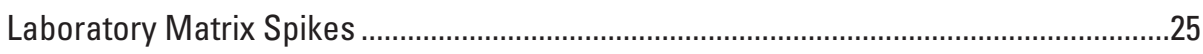

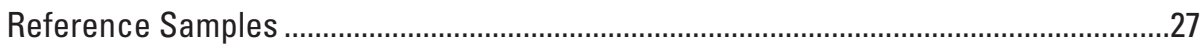

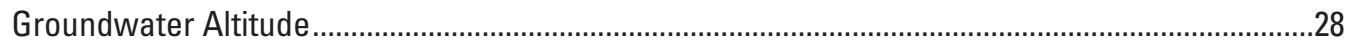

Groundwater Age

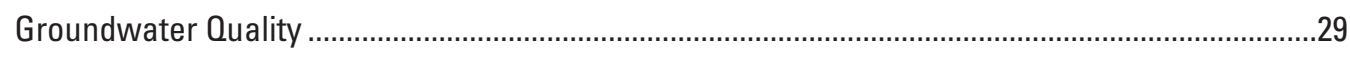

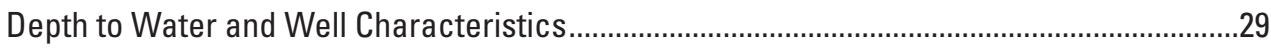

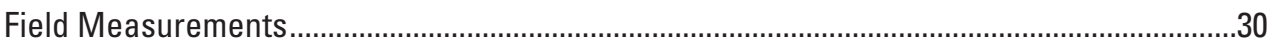

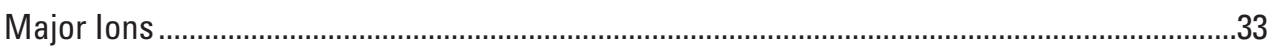

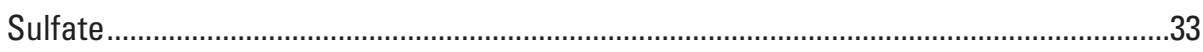

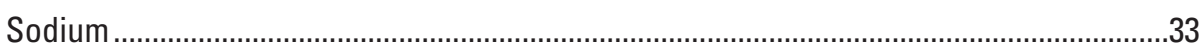

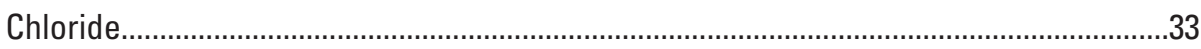


Groundwater Quality—Continued

Fluoride 38

Calcium, Magnesium, and Hardness........................................................................

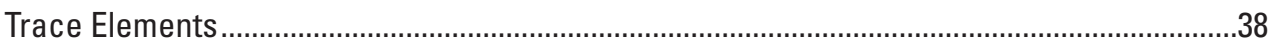

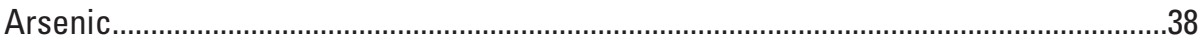

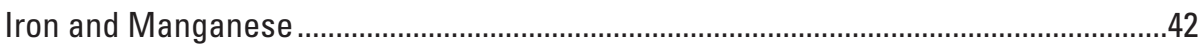

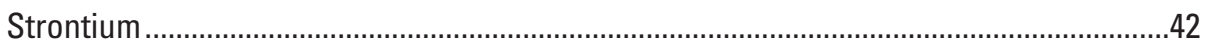

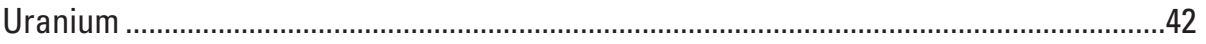

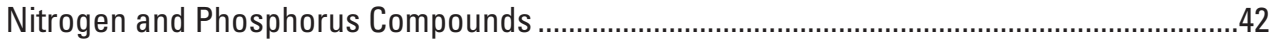

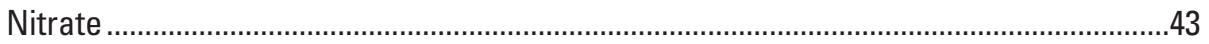

Nitrite, Ammonia, Orthophosphate Results ..............................................................51

Pesticides and Pesticide Degradates ..............................................................................

Explosives and Volatile Organic Compounds ........................................................................

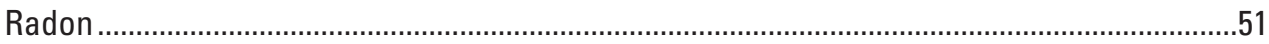

Summary of Groundwater Quality in Relation to Potential Action Levels.............................55

Alternative Approaches to Groundwater Quality Monitoring and Implications .....................55

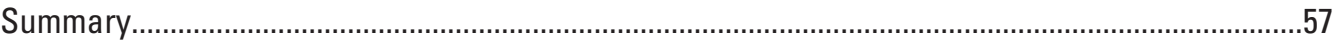

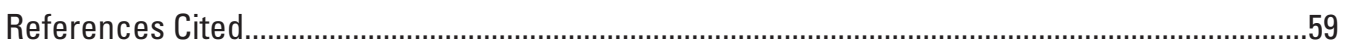

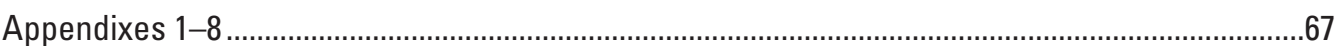

Appendix 1. Selected well-construction information for sampled wells, Papio-Missouri River Natural Resources District, eastern

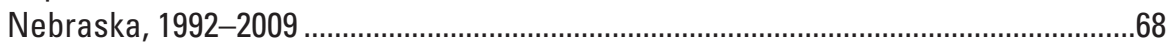

Appendix 2. List of water-quality-related data in tab-delimited data files............................68

Appendix 3. Major ions, nutrients, radionuclides, and trace elements analyzed in groundwater samples, Papio-Missouri River Natural Resources District, eastern Nebraska, 1992-2009

Appendix 4. Pesticides analyzed in groundwater samples, Papio-Missouri River Natural Resources District, eastern Nebraska, 1992-2009.........................................68

Appendix 5. Volatile organic compounds analyzed in groundwater samples, Papio-Missouri River Natural Resources District, eastern Nebraska, 2008-2009.

Appendix 6. Explosive compounds analyzed in groundwater samples, Papio-Missouri River Natural Resources District, eastern Nebraska, 2008-2009

Appendix 7. Age-dating-related analytes, dissolved gases, and stable isotopes analyzed in groundwater samples, Papio-Missouri River Natural Resources District, eastern Nebraska, 2000-2005

Appendix 8. Number of samples collected and number of analyses by type of determination for each sampled well, Papio-Missouri River Natural Resources District, eastern Nebraska, 1992-2009 


\section{Figures}

1. Map showing location of urban areas and generalized non-urban areas that have access to water from municipal or rural water systems, Papio-Missouri River Natural Resources District, eastern Nebraska

2. Map showing distribution of Quaternary alluvial aquifers, areas where Quaternary-age deposits are thin or absent, location of wells with water levels used to map the altitude of the water table in the alluvial aquifers in 2009, and generalized altitude of the water table, 2009, in the Elkhorn River Valley, Missouri River Valley, and Platte River Valley alluvial aquifers, Papio-Missouri River Natural Resources District, eastern Nebraska

3. Map showing generalized bedrock geology, location of wells screened in the Dakota aquifer with water-level data, and altitude of the predevelopment potentiometric surface of the Dakota aquifer, Papio-Missouri River Natural Resources District, eastern Nebraska.

4. Map showing distribution of estimated infiltration rates, by hydrologic soil group, Papio-Missouri River Natural Resources District, eastern Nebraska.

5. Map showing distribution of primary land-use types and graphs showing proportion of land-use types, by county or part of county, Papio-Missouri River Natural Resources District, eastern Nebraska, 2005

6. Graph showing harvested acres, by crop and county, for all counties except Dodge County, Papio-Missouri River Natural Resources District, eastern Nebraska, 1992, 1996, 2000, 2004, and 2008

7. Graphs showing $A$, total groundwater and surface-water withdrawals for all uses except those related to generation of power and $B$, groundwater withdrawals by type of use except those related to generation of power, by county, for all counties except Dodge County, Papio-Missouri River Natural Resources District, eastern Nebraska, 1990, 1995, 2000, and 2005

8. Map showing location of sampled wells, Papio-Missouri River Natural Resources District, eastern Nebraska, 1992-2009.

9. Graph showing atmospheric concentrations of chlorofluorocarbons in North American air, 1940-2010

10. Graphs showing distribution of $A$, depth to water, $B$, depth to the top of the uppermost screen, $C$, screen length, and $D$, well depth of selected wells, Papio-Missouri River Natural Resources District, eastern Nebraska, 1992-2009

11. Graphs showing distribution of $A, \mathrm{pH}, B$, dissolved oxygen, $C$, specific conductance, and $D$, water temperature in selected samples, Papio-Missouri River Natural Resources District, eastern Nebraska, 1992-2009.

12. Trilinear diagram showing ionic composition of groundwater in the $A$, Dakota aquifer, $B$, Elkhorn River Valley alluvial aquifer, $C$, Missouri River Valley alluvial aquifer, $D$, Platte River Valley alluvial aquifer, and $E$, upland area alluvial aquifers, in the most recent samples in network wells and all wells in the well nests, Papio-Missouri River Natural Resources District, eastern Nebraska, 1992-2009

13. Map showing distribution of arsenic concentrations in the most recent samples in network wells and wells in well nests, Papio-Missouri River Natural Resources District, eastern Nebraska, 1992-2009. 
14. Graphs showing concentrations, by aquifer, of $A$, arsenic, $B$, iron, $C$, manganese, $D$, strontium, and $E$, uranium as a frequency distribution using box plots in the most recent samples in network wells in 1992 and in one randomly selected well in each well nest in 2008, and as results using dot plots for all sampled wells in well nests in 2008, Papio-Missouri River Natural Resources District, eastern Nebraska.

15. Graphs showing frequency distribution of nitrate plus nitrite concentration $A$, by aquifer and $B$, by dissolved oxygen range in the most recent summer-to-fall samples in network wells and in one randomly selected well in each well nest, Papio-Missouri River Natural Resources District, eastern Nebraska, 1992-2009

16. Graphs showing frequency distribution of nitrate plus nitrite concentration, by aquifer, in the most recent summer-to-fall samples $A$, in network wells, 1992-1994, and $B$, in network wells and one randomly selected well in each well nest, 2007-2009, Papio-Missouri River Natural Resources District, eastern Nebraska

17. Map showing distribution of the most recent summer-to-fall nitrate plus nitrite concentration for each sampled well, Papio-Missouri River Natural Resources District, eastern Nebraska, 2007-2009.

18. Graphs showing concentrations of dissolved oxygen and nitrate plus nitrite in samples collected from wells in the $A$, well nest in Tekamah, Nebraska, $B$, well nest near Venice, Nebraska, and $C$, well nest near Springfield, Nebraska, Papio-Missouri River Natural Resources District, eastern Nebraska, 1999-2009

19. Graph showing the most recent concentration of pesticide compounds that were detected at levels greater than the maximum laboratory reporting level, in each sampled well, Papio-Missouri River Natural Resources District, eastern Nebraska, 2007-2009.

20. Map showing distribution of number of pesticide compounds detected, by well and by aquifer, in sampled wells, Papio-Missouri River Natural Resources District, eastern Nebraska, 2007-2009

21. Map showing distribution of ${ }^{222}$ radon activity in the most recent samples in network wells and wells in well nests, Papio-Missouri River Natural Resources District, eastern Nebraska, 1992-2009. 


\section{Tables}

1. Description of hydrogeologic units, Papio-Missouri River Natural Resources District, eastern Nebraska.

2. Estimated nonpoint-source inputs of nitrogen and phosphorus, by county, Papio-Missouri River Natural Resources District, eastern Nebraska, 2001

3. Ten most commonly applied pesticides, estimated treated area, and average pesticide application rate, by county, Papio-Missouri River Natural Resources District, eastern Nebraska, 2005

4. Laboratory analytical methods and field preservation procedures for water-quality constituents, Papio-Missouri River Natural Resources District, eastern Nebraska, 1992-2009.

5. Constitutents detected in field-blank samples, Papio-Missouri River Natural Resources District, eastern Nebraska, 1992-2009.

6. Summary of relative percent differences for replicate samples and percent recoveries for laboratory matrix-spike and reference samples, Papio-Missouri River Natural Resources District, eastern Nebraska, 1992-2009.

7. Analytical results for dissolved gases and chlorofluorocarbons in samples collected in 2000 and calculated results associated with determining the apparent age of groundwater using chlorofluorocarbons, Papio-Missouri River Natural Resources District, eastern Nebraska

8. Summary statistics for well characteristics and depth to water in selected wells and field measurements from the most recent summer-to-fall samples from selected wells, Papio-Missouri River Natural Resources District, eastern Nebraska, 1992-2009.

9. Range of oxidation-reduction classifications, by well, for samples from selected wells in well nests, Papio-Missouri River Natural Resources District, eastern Nebraska, 1999-2009

10. Summary statistics for major ions, hardness, silica, and nutrients in the most recent selected groundwater samples collected in the network wells and in one randomly selected well in each well nest, Papio-Missouri River Natural Resources District, eastern Nebraska, 1992-2009.

11. Summary statistics for trace elements in the most recent samples collected in network wells and in one randomly selected well in each well nest, Papio-Missouri River Natural Resources District, eastern Nebraska, 1992-2009

12. Estimated recharge temperature, excess nitrogen gas, initial nitrate concentration, and fraction of initial nitrate in recharge that has been removed by denitrification using dissolved gases and related data, Papio-Missouri River Natural Resources District, eastern Nebraska, 2000 and 2004.

13. Summary statistics for ${ }^{222}$ radon activity in the most recent samples collected in network wells and in one randomly selected well in each well nest, Papio-Missouri River Natural Resources District, eastern Nebraska, 1992-2009

14. Summary of major ions, nutrients, pesticides, and trace elements results in the most recent selected samples in network wells and in one randomly selected well in each well nest, and number of analyte concentrations that are at least 30 , 50 , or 100 percent of applicable Federal drinking-water or Nebraska Title-118 standards, Papio-Missouri River Natural Resources District, eastern Nebraska, 1992-2009.. 


\section{Conversion Factors and Datums}

Inch/Pound to SI

\begin{tabular}{|c|c|c|}
\hline Multiply & By & To obtain \\
\hline \multicolumn{3}{|c|}{ Length } \\
\hline inch (in.) & 2.54 & centimeter $(\mathrm{cm})$ \\
\hline inch (in.) & 25.4 & millimeter (mm) \\
\hline inch (in.) & 25,400 & micrometer $(\mu \mathrm{m})$ \\
\hline foot $(\mathrm{ft})$ & 0.3048 & meter $(\mathrm{m})$ \\
\hline mile (mi) & 1.609 & kilometer $(\mathrm{km})$ \\
\hline \multicolumn{3}{|c|}{ Area } \\
\hline acre & 0.004047 & square kilometer $\left(\mathrm{km}^{2}\right)$ \\
\hline $\begin{array}{l}\text { section ( } 640 \text { acres or } 1 \text { square } \\
\text { mile) }\end{array}$ & 259.0 & square hectometer $\left(\mathrm{hm}^{2}\right)$ \\
\hline square mile $\left(\mathrm{mi}^{2}\right)$ & 2.590 & square kilometer $\left(\mathrm{km}^{2}\right)$ \\
\hline \multicolumn{3}{|c|}{ Volume } \\
\hline gallon (gal) & 3.785 & liter $(\mathrm{L})$ \\
\hline gallon (gal) & 0.00378 & milliliter (mL) \\
\hline gallon (gal) & 0.003785 & cubic meter $\left(\mathrm{m}^{3}\right)$ \\
\hline million gallons (Mgal) & 3,785 & cubic meter $\left(\mathrm{m}^{3}\right)$ \\
\hline cubic inch $\left(\right.$ in $\left.^{3}\right)$ & 0.01639 & liter $(\mathrm{L})$ \\
\hline \multicolumn{3}{|c|}{ Flow rate } \\
\hline foot per day (ft/d) & 0.3048 & meter per day $(\mathrm{m} / \mathrm{d})$ \\
\hline gallons per minute (gal/min) & 0.06309 & liter per second $(\mathrm{L} / \mathrm{s})$ \\
\hline million gallons per day (Mgal/d) & 0.04381 & cubic meter per second $\left(\mathrm{m}^{3} / \mathrm{s}\right)$ \\
\hline inch per year (in/yr) & 2.54 & centimeters per year (cm/yr) \\
\hline \multicolumn{3}{|c|}{ Mass } \\
\hline pound, avoirdupois (lb) & 0.4536 & kilogram (kg) \\
\hline \multicolumn{3}{|c|}{ Radioactivity } \\
\hline picocurie per liter $(\mathrm{pCi} / \mathrm{L})$ & 0.037 & becquerel per liter $(\mathrm{Bq} / \mathrm{L})$ \\
\hline millirem (mrem) & 10,000 & microsievert $(\mu \mathrm{Sv})$ \\
\hline \multicolumn{3}{|c|}{ Hydraulic conductivity } \\
\hline foot per day $(\mathrm{ft} / \mathrm{d})$ & 0.3048 & meter per day $(\mathrm{m} / \mathrm{d})$ \\
\hline \multicolumn{3}{|c|}{ Hydraulic gradient } \\
\hline foot per mile ( $\mathrm{ft} / \mathrm{mi})$ & 0.1894 & meter per kilometer $(\mathrm{m} / \mathrm{km})$ \\
\hline \multicolumn{3}{|c|}{ Application rate } \\
\hline $\begin{array}{l}\text { pounds per acre per year } \\
{[(\mathrm{lb} / \mathrm{acre}) / \mathrm{yr}]}\end{array}$ & 1.121 & $\begin{array}{l}\text { kilograms per hectare per year } \\
{[(\mathrm{kg} / \mathrm{ha}) / \mathrm{yr}]}\end{array}$ \\
\hline
\end{tabular}


Temperature in degrees Celsius $\left({ }^{\circ} \mathrm{C}\right)$ may be converted to degrees Fahrenheit $\left({ }^{\circ} \mathrm{F}\right)$ as follows:

$$
{ }^{\circ} \mathrm{F}=\left(1.8 \times^{\circ} \mathrm{C}\right)+32
$$

Temperature in degrees Fahrenheit $\left({ }^{\circ} \mathrm{F}\right)$ may be converted to degrees Celsius $\left({ }^{\circ} \mathrm{C}\right)$ as follows:

$$
{ }^{\circ} \mathrm{C}=\left({ }^{\circ} \mathrm{F}-32\right) / 1.8
$$

Altitude or vertical coordinate information is referenced to the National Geodetic Vertical Datum of 1929 (NGVD 29). Altitude refers to distance above or below NGVD 29. NGVD 29 can be converted to the North American Vertical Datum of 1988 by using the National Geodetic Survey conversion utility available at $h t t p: / / w w w . n g s . n o a a . g o v / T O O L S /$ Vertcon/vertcon.html.

Horizontal coordinate information is referenced to the North American Datum of 1983 (NAD 83).

Specific conductance is given in microsiemens per centimeter at 25 degrees Celsius $(\mu \mathrm{S} / \mathrm{cm}$ at $\left.25^{\circ} \mathrm{C}\right)$.

Concentrations of chemical constituents in water are given in milligrams per liter $(\mathrm{mg} / \mathrm{L})$, micrograms per liter $(\mu \mathrm{g} / \mathrm{L})$, or micromoles per liter $(\mu \mathrm{M} / \mathrm{L})$.

Water year is the 12-month period from October 1 through September 30. The water year is designated by the calendar year in which the water year ends and that includes 9 of the 12 months. Thus, the water year ending September 30, 2009, is called the "2009 water year."

\section{Acknowledgments}

The authors thank cooperative well owners and city water officials for their generosity in allowing the U.S. Geological Survey access to collect samples from their wells. The authors also thank the staff of the Papio-Missouri River Natural Resources District for their assistance in this study.

U.S. Geological Survey colleagues Matt Landon, Greg Steele, and Jill Frankforter provided valuable comments that substantially improved this report. 



\title{
Altitude, Age, and Quality of Groundwater, Papio-Missouri River Natural Resources District, Eastern Nebraska, 1992 to 2009
}

\author{
By Virginia L. McGuire, Derek W. Ryter, and Amanda S. Flynn
}

\section{Abstract}

The U.S. Geological Survey, in cooperation with the Papio-Missouri River Natural Resources District (PMRNRD), conducted this study to map the water-level altitude of 2009 within the Elkhorn River Valley, Missouri River Valley, and Platte River Valley alluvial aquifers; to present the predevelopment potentiometric-surface altitude within the Dakota aquifer; and to describe the age and quality of groundwater in the five principal aquifers of the PMRNRD in eastern Nebraska using data collected from 1992 to 2009. In addition, implications of alternatives to the current PMRNRD groundwaterquality monitoring approach are discussed.

In the PMRNRD, groundwater altitude, relative to National Geodetic Vertical Datum of 1929, ranged from about 1,080 feet (ft) to $1,180 \mathrm{ft}$ in the Elkhorn River Valley alluvial aquifer and from about $960 \mathrm{ft}$ to $1,080 \mathrm{ft}$ in the Missouri River Valley and Platte River Valley alluvial aquifers. In the PMRNRD, the estimated altitude of the potentiometric surface of the Dakota aquifer, predevelopment, ranged from about $1,100 \mathrm{ft}$ to $1,200 \mathrm{ft}$.

To assess groundwater age and quality, groundwater samples were collected from a total of 217 wells from 1992 to 2009 for analysis of various analytes. Groundwater samples collected in the PMRNRD from 1992 to 2009 and interpreted in this report were analyzed for age-dating analytes (chlorofluorocarbons), dissolved gases, major ions, trace elements, nutrients, stable isotope ratios, pesticides and pesticide degradates, volatile organic compounds, explosives, and ${ }^{222}$ radon.

Apparent groundwater age was estimated from concentrations of chlorofluorocarbons measured in samples collected in 2000. Apparent groundwater-recharge dates ranged from older than 1940 in samples from wells screened in the Missouri River Valley alluvial aquifer to the early 1980s in samples from wells screened in the Dakota aquifer.

Concentrations of major ions in the most recent sample per well collected from 1992 to 2009 indicate that the predominant water type was calcium bicarbonate. Samples from 4 wells exceeded the U.S. Environmental Protection Agency (USEPA) Secondary Drinking Water Regulation (SDWR) for sulfate [250 milligrams per liter $(\mathrm{mg} / \mathrm{L})$ ], and samples from
4 wells exceeded the USEPA Drinking Water Advisory Table for sodium $(30-60 \mathrm{mg} / \mathrm{L})$.

Eighteen of the 21 trace elements analyzed in samples from PMRNRD wells have USEPA drinking-water standards. Sixteen of the trace elements with USEPA standards were detected in the selected samples. In the samples selected for trace-element analysis, the only trace-element concentration that exceeded an enforceable USEPA drinking-water standard, the Maximum Contaminant Level (MCL), was for arsenic; arsenic concentration exceeded the USEPA MCL of 10 micrograms per liter $(\mu \mathrm{g} / \mathrm{L})$ in 4 percent of the samples. Traceelement concentrations that exceeded the USEPA SDWR or Lifetime Health Advisory level were iron (46 percent of the samples were greater than USEPA SDWR of $300 \mu \mathrm{g} / \mathrm{L}$ ), manganese (70 percent of the samples were greater than USEPA SDWR of $50 \mu \mathrm{g} / \mathrm{L}$ ), and strontium (4 percent of the samples were greater than USEPA Lifetime Health Advisory level of $4,000 \mu \mathrm{g} / \mathrm{L})$.

The concentration of nitrate plus nitrite as nitrogen (nitrate-N) in the most recent nutrient samples collected from the network wells and from one randomly selected well in the well nests from 1992 to 2009 for most wells (80 percent) ranged from less than 0.06 to $8.55 \mathrm{mg} / \mathrm{L}$, with a median value of $0.12 \mathrm{mg} / \mathrm{L}$. Concentrations of nitrate-N in 13 (7 percent) nutrient samples, 1992 to 2009 , were greater than or equal to the USEPA MCL and Nebraska Title-118 standard of $10 \mathrm{mg} / \mathrm{L}$, and concentrations of nitrate- $\mathrm{N}$ in 35 (18 percent) nutrient samples, 1992 to 2009, were greater than or equal to $5 \mathrm{mg} / \mathrm{L}$, which is the PMRNRD action level for possible management implementation to reduce nitrate concentrations in groundwater.

Of the 61 pesticides or pesticide degradates analyzed from 2007 to 2009, 21 were detected. Three of the 21 pesticides detected (alachlor, atrazine, and metolachlor) have established health-based criteria; all detections of these compounds were at concentrations less than their USEPA standards. From 2007 to 2009,1 or more pesticide compounds were detected in 16 of the 82 network wells and in 18 of the 26 wells in well nests. From 2007 to 2009, the individual pesticide compounds that were detected most frequently were alachlor ethane sulfonic acid, a degradate of alachlor; deethylcyanazine acid, a degradate of cyanazine; and atrazine. 
Analytes with concentrations that exceeded 30 percent of the applicable Nebraska Title-118 standard were identified so that the PMRNRD can plan to monitor groundwater in the area and consider possible actions should the analyte concentrations continue to rise. The analytical results from the most recent samples collected in the network wells and all the wells in well nests from 1992 to 2009 indicate that, in at least 1 sample, there was a concentration that exceeded 30 percent of the Nebraska Title-118 standard for at least 1 of 3 major ions (chloride, fluoride, and sulfate), 1 nutrient (nitrate-N), 1 pesticide (atrazine), or 3 trace elements (arsenic, iron, and manganese). In addition, 30 percent of the USEPA MCL or Nebraska Title-118 standard for gross alpha activity likely was exceeded in samples from three wells screened in the Dakota aquifer. Study findings indicate that some alternatives to the current PMRNRD groundwater-sampling approach that could be considered are to collect fewer samples for nutrient analysis and to collect samples periodically for determining concentrations of additional analytes, particularly the analytes with concentrations that were at least 30 percent or more than the Nebraska Title-118 standard.

\section{Introduction}

The groundwater resources of the Papio-Missouri River Natural Resources District (PMRNRD) comprise five principal aquifers - the Dakota aquifer and Elkhorn River Valley, Missouri River Valley, Platte River Valley, and upland area alluvial aquifers. In December 1989, PMRNRD management submitted a groundwater-management plan for the district to the Nebraska Department of Environmental Quality (PapioMissouri River Natural Resources District, 1989) as required by the Nebraska Groundwater Management and Protection Act (State of Nebraska, variously dated). In 1991, Nebraska passed legislation (LB51) requiring each Natural Resources District (NRD) to amend the water-quality section of its groundwatermanagement plan by July 1,1993 , to “...identify...levels and sources of ground water contamination within the district... and practices recommended to stabilize, reduce, and prevent the occurrence, increase, or spread of ground water contamination" (State of Nebraska, variously dated). The PMRNRD submitted a revised groundwater-management plan in 1994 (Papio-Missouri River Natural Resources District, 1994). The PMRNRD revised groundwater-management plan states that if an analyte concentration exceeds 50 percent of its Nebraska Title-118 standard, "a management, control, or special protection area will be strongly pursued" (Papio-Missouri River Natural Resources District, 1994).

In 1991, knowledge of the quality of groundwater in the PMRNRD was limited to information on major-ion chemistry, dissolved nitrate plus nitrite as nitrogen (hereinafter referred to as nitrate-N), pesticides, and uranium (Exner, 1980; U.S. Department of Energy, 1981; Engberg, 1984; Spaulding, 1990). After a reconnaissance study in 1992, Verstraeten and Ellis (1995) concluded that groundwater quality in the PMRNRD principal aquifers was generally suitable for most uses; however, detections of pesticides and a limited number of constituent concentrations that exceeded the U.S. Environmental Protection Agency (USEPA) Maximum Contaminant Level (MCL), USEPA Secondary Drinking Water Regulations (SDWR), or Nebraska Title-118 were of concern (Nebraska Department of Environmental Quality, 2006; U.S. Environmental Protection Agency, 2009a). From 1994 to 2009, the U.S. Geological Survey (USGS), in cooperation with the PMRNRD, monitored groundwater quality in the PMRNRD, and in 2007, the USGS began this study to interpret and report the groundwater or potentiometric-surface altitude in 4 of the 5 PMRNRD principal aquifers, age-dating results for the 5 principal aquifers of the PMRNRD for 2000, and water-quality results for the 5 principal aquifers of the PMRNRD from 1992 to 2009. The objective of this study was to provide a current (2011), robust analysis of the groundwater-quality results from 1992 to 2009 sampling to aid PMRNRD management in making decisions and plans regarding groundwater quality in the district.

The purposes of this report are to present the water-level altitudes within the Elkhorn River Valley, Missouri River Valley, and Platte River Valley alluvial aquifers; to present the predevelopment potentiometric-surface altitude within the Dakota aquifer; and to describe the age and quality of groundwater in the five principal aquifers of the PMRNRD in eastern Nebraska using data collected from 1992 to 2009. In addition, implications of alternatives to the current PMRNRD groundwater-quality monitoring approach are discussed.

The scope of this report is to (1) define the waterlevel altitudes within the alluvial aquifers generally using groundwater-level measurements from spring 2009 and estimated surface-water altitudes, (2) present predevelopment potentiometric-surface altitudes and the altitude of available groundwater-level measurements from spring 2009 in the Dakota aquifer, (3) describe the groundwater-quality monitoring approach and the analytical methods used in the PMRNRD sampling program from 1992 to 2009, (4) present the analytical results for the regular and quality-control (QC) samples for the PMRNRD sampling program from 1992 to 2009, and (5) discuss results of statistical comparisons among selected constituents of groundwater quality. Results of groundwaterquality analyses were statistically compared for the periods 1992 to 2009, 1992 to 1994, 1999 to 2009, and 2007 to 2009. Gross alpha and beta activities, ${ }^{226}$ radium activities, and the ${ }^{234}$ uranium: ${ }^{238}$ uranium ratios from samples collected in 1992 were not interpreted in this report because samples have not been collected for analysis of these radionuclides since 1992, and Verstraeten and Ellis (1995) interpreted the 1992 results.

\section{Description of Study Area}

The PMRNRD encompasses approximately 1,790 square miles $\left(\mathrm{mi}^{2}\right)$ [4,640 square kilometers $\left.\left(\mathrm{km}^{2}\right)\right]$ in eastern Nebraska (fig. 1); the PMRNRD includes all or parts of seven 


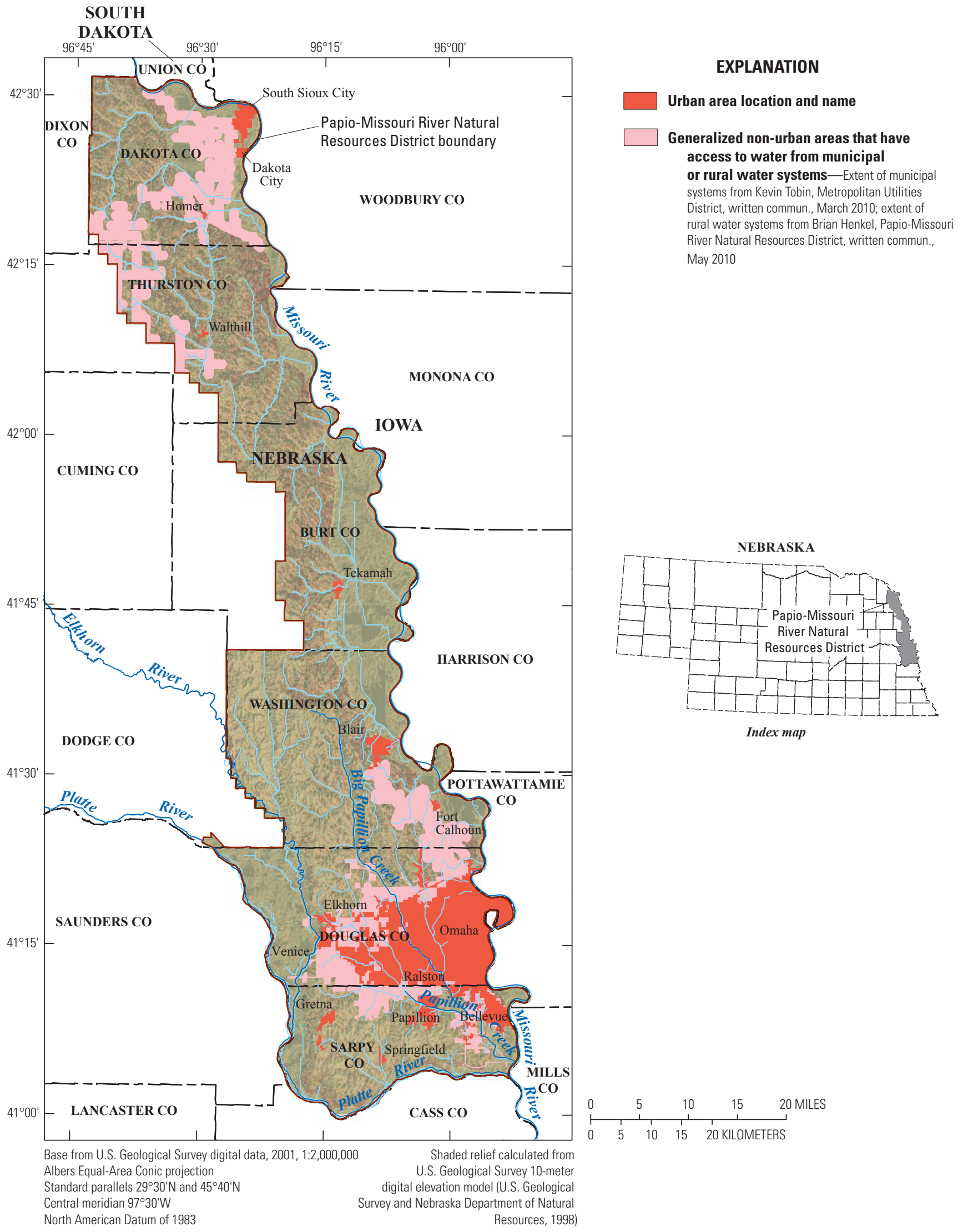

Figure 1. Location of urban areas and generalized non-urban areas that have access to water from municipal or rural water systems, Papio-Missouri River Natural Resources District, eastern Nebraska. 
counties in eastern Nebraska-Burt (58 percent), Dakota (98 percent), Dodge (less than 1 percent), Douglas (100 percent), Sarpy (100 percent), Thurston (65 percent), and Washington (100 percent). In this report, the small area of the PMRNRD in Dodge County is not discussed in county summaries because it was not considered to be relevant. Major cities in the PMRNRD are, in order of decreasing population, Omaha, Bellevue, Papillion, South Sioux City, Blair, Ralston, Elkhorn, Gretna, Tekamah, and Dakota City (U.S. Census Bureau, 2001).

The PMRNRD is bounded on the east by the Missouri River and to the south and southwest by the Platte and Elkhorn Rivers. In the northwest, the PMRNRD is bounded by the Dakota and Washington County boundaries and, in Thurston and Burt County, by the western edge of the Missouri River watershed boundary (Watermolen, 2005). Other major streams in the PMRNRD include Papillion Creek and its tributaries (fig. 1). The Elkhorn River is a tributary to the Platte River; the Platte River and Papillion Creek are tributaries to the Missouri River.

The PMRNRD is located in the Dissected Till Plains section of the Central Lowland physiographic province (Fenneman, 1938). The land-surface altitude of the PMRNRD, relative to the National Geodetic Vertical Datum of 1929 (NGVD 29), ranges from about 1,520 feet (ft) [460 meters (m)] in the uplands on the western side of the study area to about $950 \mathrm{ft}(290 \mathrm{~m})$ in the Missouri River Valley at the Platte River confluence. The principal physiographic features are nearly level river valleys bordered by steep bluffs and escarpments with irregular slopes or uplands. The glaciated uplands consist of gently rolling ridges and valleys formed by erosion and deposition. The deposits in the uplands primarily consist of relatively impermeable glacial till overlain by thin to thick layers of eolian loess (University of NebraskaLincoln, Conservation and Survey Division, 1986).

The climate in the PMRNRD is continental and temperate with large seasonal variations in temperature and precipitation. The climate (from 1948 to 2009 monthly climatic summaries for Omaha and for the vicinity of South Sioux City, Nebr.) is characterized by moderate precipitation [30.4 inches per year (in./yr) or 77.2 centimeters per year $(\mathrm{cm} / \mathrm{yr})$ in Omaha and $26.5 \mathrm{in} . / \mathrm{yr}$ or $67.3 \mathrm{~cm} / \mathrm{yr}$ near South Sioux City] and a wide range of daily average temperatures [12.0 to 87.7 degrees Fahrenheit $\left({ }^{\circ} \mathrm{F}\right)$ or -11.1 to 30.9 degrees Celsius $\left({ }^{\circ} \mathrm{C}\right)$ in Omaha and 8.4 to $86.2^{\circ} \mathrm{F}$ or -13.1 to $30.1^{\circ} \mathrm{C}$ near South Sioux City] (High Plains Regional Climate Center, 2010a and 2010b). About 73 percent of the precipitation is received as rainfall during April through September.

\section{Hydrogeology}

Verstraeten and Ellis (1995) describe the hydrogeology in the PMRNRD area on the basis of geologic and hydrogeologic information in published reports and unpublished data available at the University of Nebraska-Lincoln, Conservation and Survey Division (UNL-CSD) and the USGS office in Lincoln, Nebr. For this report, six aquifers are distinguished as groundwater resources of the PMRNRD (table 1). Four of these are composed of surficial deposits, and two are bedrock aquifers. The surficial and bedrock hydrogeologic characteristics are described briefly in separate subsections that follow this subsection.

The geology and hydrogeologic characteristics of the PMRNRD area in Dakota County are described by Condra (1908) and Todd (1908). The geology of the Omaha area is described by Condra and others (1931) and Miller (1964). Geologic characteristics of the Missouri River Valley alluvium and bedrock are reported by Burchett (1965); the hydrogeology of the Dakota aquifer is discussed by O'Connor (1987). Lithologic logs with the altitudes of geologic formations from test holes drilled by UNL-CSD and USGS in the PMRNRD area are presented by Burchett and Smith (1989a, 1989b, 1989c, 1991a, 1991b, 1992) and the University of NebraskaLincoln, Conservation and Survey Division (2010c). Other relevant publications on the geology and hydrogeology of Nebraska include Condra and Reed (1959), Reed and Dreeszen (1965), Dreeszen (1970), Burchett and others (1975 and 1988), Nebraska Department of Environmental Quality and UNL-CSD (1980a, 1980b, 1980c, and 1980d), Ellis (1984 and 1986), Helgesen and others (1993), Jorgensen and others (1993 and 1996), University of Nebraska-Lincoln, Conservation and Survey Division (1996, 2010a, 2010b), Soller and Packard (1998), and Shroba and others (2002). In addition, Gutentag and others (1984) discussed the characteristics of the High Plains aquifer, which includes most of the Elkhorn River Valley alluvial aquifer.

\section{Hydrogeologic Units in Surficial Deposits}

The surficial deposits in the PMRNRD are predominantly Quaternary-age deposits of alluvial, eolian, and glacial origin. The Quaternary-age deposits are unconsolidated and vary from relatively permeable sand-and-gravel units to relatively impermeable silts and clays. Only the sand-and-gravel units were considered aquifers for this study. In this report, the Quaternary-aged sand-and-gravel deposits in the PMRNRD area are divided into four aquifers (Verstraeten and Ellis, 1995) - the Elkhorn River Valley, Missouri River Valley, Platte River Valley, and upland area alluvial aquifers (fig. 2). Additional discussion of the composition and characteristics of surficial deposits in the PMRNRD can be found in Verstraeten and Ellis (1995).

\section{Bedrock Hydrogeologic Units}

The PMRNRD is underlain by bedrock formations ranging in age from Precambrian through Cretaceous; bedrock formations of Permian, Triassic, and Jurassic age are not present in the PMRNRD. The surficial (uppermost) bedrock formations in the PMRNRD range in age from Pennsylvanian to Cretaceous (fig. 3). The bedrock underlying the PMRNRD is divided into five hydrogeologic units - the Great Plains 
Table 1. Description of hydrogeologic units, Papio-Missouri River Natural Resources District, eastern Nebraska.

[Descriptions modified from Verstraeten and Ellis (1995) and Jorgensen and others (1993). PMRNRD, Papio-Missouri River Natural Resources District; ft, feet; gal/min, gallons per minute; depths are in feet below land surface]

\begin{tabular}{|c|c|c|c|}
\hline Era & System & Geologic unit & $\begin{array}{c}\text { Geologic characterization, description, } \\
\text { and distribution }\end{array}$ \\
\hline Cenozoic & Quaternary & $\begin{array}{l}\text { Undifferentiated deposits of } \\
\text { Holocene and Pleistocene } \\
\text { age }\end{array}$ & $\begin{array}{l}\text { Clay, silt, sand, and gravel. Includes eolian, glacial, and } \\
\text { alluvial deposits found over almost all of the PMRNRD } \\
\text { area, except in small areas where bedrock crops out. } \\
\text { The total thickness of the deposits in river valleys in the } \\
\text { PMRNRD are usually less than } 100 \mathrm{ft} \text {. In the upland part } \\
\text { of the PMRNRD, the total thickness of the deposits usu- } \\
\text { ally ranges from } 50 \text { to } 250 \mathrm{ft} \text {; maximum thickness of the } \\
\text { deposits in the upland area is about } 300 \mathrm{ft} \text { and is in the } \\
\text { northern part of the PMRNRD. Eolian deposits are loess, } \\
\text { consisting of silt- and clay-sized grains, and usually are } \\
\text { the surficial deposits in upland areas of the PMRNRD. } \\
\text { Loess thickness usually ranges from } 10 \text { to } 50 \mathrm{ft} \text {. Glacial } \\
\text { deposits are clay tills that contain silt, sand, and gravel } \\
\text { and underlie the eolian deposits in most of the upland } \\
\text { areas of the PMRNRD. Glacial deposits occur in the } \\
\text { form of multiple till beds, and total thickness usually is } \\
25 \text { to } 125 \mathrm{ft} \text { but may be as much as } 175 \mathrm{ft} \text { or be absent } \\
\text { due to erosion. Alluvial deposits include clay, silt, sand, } \\
\text { and gravel. Clay and silt deposits usually are intermixed } \\
\text { or interbedded with the sand and gravel deposits. Sand } \\
\text { and gravel deposits are most common in the river val- } \\
\text { leys. }\end{array}$ \\
\hline Mesozoic & Cretaceous & $\begin{array}{l}\text { Undifferentiated Carlile Shale, } \\
\text { Greenhorn Limestone, and } \\
\text { Graneros Shale }\end{array}$ & $\begin{array}{l}\text { Shale, marl, and limestone. Shale is calcareous. Limestone } \\
\text { is thin-bedded, argillaceous, and interbedded with marl } \\
\text { and shale beds. Present in parts of Dakota and Thurston } \\
\text { Counties. Maximum thickness is about } 125 \mathrm{ft} \text { in Dakota } \\
\text { County. }\end{array}$ \\
\hline
\end{tabular}

Dakota Sandstone Formation Sandstone and claystone. Sandstone is very fine to coarsegrained, lenticular, friable, and locally is iron oxide. About 70 percent of the formation is sandstone. Claystone is massive and often silty. Maximum thickness, about $500 \mathrm{ft}$, is in Dakota and Thurston Counties where the unit is primarily sandstone and overlain by Graneros Shale. In the rest of the PMRNRD, the formation thins toward the south and east due to erosion. Erosional remnants that are less than $20 \mathrm{ft}$ thick occur in Sarpy County.

Hydrogeologic unit

alluvial aquifer

Missouri River Valley alluvial aquifer

Platte River Valley alluvial aquifer

Upland area alluvial aquifers

Great Plains confining system

Dakota aquifer (part of the Great Plain aquifer system)

\section{Hydrogeologic characteristics}

Unconfined aquifer with wells yielding 700 to

$1,200 \mathrm{gal} / \mathrm{min}$. Depth to water ranges from about 5 to $30 \mathrm{ft}$. Saturated thickness ranges from 50 to $90 \mathrm{ft}$.

Aquifer usually unconfined but locally may be partially confined. Most wells yield 600 to $1,200 \mathrm{gal} / \mathrm{min}$.

Depth to water ranges from about 5 to $40 \mathrm{ft}$. Saturated thickness ranges from 70 to $100 \mathrm{ft}$.

Unconfined aquifer with wells yielding 900 to $2,000 \mathrm{gal} / \mathrm{min}$. Depth to water ranges from about 5 to $15 \mathrm{ft}$. The saturated thickness ranges from 60 to $100 \mathrm{ft}$.

Confined or partially confined discontinuous beds of saturated sand and gravel. Well yields range from 10 to $300 \mathrm{gal} / \mathrm{min}$. Depth to water ranges from about 10 to $170 \mathrm{ft}$. The saturated thickness of the sand and gravel deposits usually is less than $20 \mathrm{ft}$.

Forms a regional confining unit that, where present, separates the Dakota aquifer from the overlying alluvial aquifers.

Confined or partially confined aquifer with wells yielding 10 to $600 \mathrm{gal} / \mathrm{min}$ depending on the thickness of the saturated sandstone. Depth to water ranges from about 5 to $200 \mathrm{ft}$. The sandstone thickness ranges from less than 1 to about $300 \mathrm{ft}$. 
Table 1. Description of hydrogeologic units, Papio-Missouri River Natural Resources District, eastern Nebraska.—Continued

[Descriptions modified from Verstraeten and Ellis (1995) and Jorgensen and others (1993). PMRNRD, Papio-Missouri River Natural Resources District; ft, feet; gal/min, gallons per minute; depths are in feet below land surface]

\begin{tabular}{|c|c|c|c|c|c|}
\hline Era & System & Geologic unit & $\begin{array}{c}\text { Geologic characterization, description, } \\
\text { and distribution }\end{array}$ & Hydrogeologic unit & Hydrogeologic characteristics \\
\hline \multirow[t]{2}{*}{ Paleozoic } & Pennsylvanian & $\begin{array}{l}\text { Undifferentiated limestone, } \\
\text { shale, and sandstone beds }\end{array}$ & $\begin{array}{l}\text { Limestone and shale. Limestone is thin-bedded to mas- } \\
\text { sive and usually dense. Shale is calcareous and fissile. } \\
\text { Maximum thickness, about } 500 \mathrm{ft} \text {, is in southwestern } \\
\text { part of the PMRNRD. These sediments are absent in the } \\
\text { northern part of Dakota County. }\end{array}$ & $\begin{array}{l}\text { Western Interior Plains } \\
\text { confining system }\end{array}$ & $\begin{array}{l}\text { Forms a regional confining bed that, where present } \\
\text { in the PMRNRD, separates the Western Interior } \\
\text { Plains aquifer system from the Dakota aquifer and } \\
\text { from the alluvial aquifers. In the PMRNRD, wells } \\
\text { completed in local fracture zones near the top of the } \\
\text { unit may yield } 5 \text { to } 50 \mathrm{gal} / \mathrm{min} \text {. }\end{array}$ \\
\hline & $\begin{array}{l}\text { Mississippian- } \\
\text { Cambrian, } \\
\text { undifferentiated }\end{array}$ & $\begin{array}{l}\text { Undifferentiated limestone, } \\
\text { dolomite, sandstone, and } \\
\text { shale beds }\end{array}$ & $\begin{array}{l}\text { Predominantly massive dolomite bedding with some } \\
\text { limestone beds in upper part, thin dolomitic shale in the } \\
\text { middle, and sandstone beds in the lower parts. Thickness } \\
\text { increases from about } 900 \mathrm{ft} \text { in Dakota County to } 1,600 \mathrm{ft} \\
\text { in Washington County. Thickness decreases to the south } \\
\text { and east. }\end{array}$ & $\begin{array}{l}\text { Western Interior Plains } \\
\text { aquifer system }\end{array}$ & $\begin{array}{l}\text { Confined aquifers. Available information indicates } \\
\text { that, in the PMRNRD, well yields range from } 200 \mathrm{to} \\
1,300 \mathrm{gal} / \mathrm{min} \text {, water levels range from } 150 \text { to } 300 \mathrm{ft} \\
\text { below land surface, and well depths range from } \\
1,100 \text { to } 2,400 \mathrm{ft} \text {. }\end{array}$ \\
\hline Precambrian & Undifferentiated & Undifferentiated & $\begin{array}{l}\text { Undifferentiated igneous, metamorphic, and sedimentary } \\
\text { rocks. }\end{array}$ & $\begin{array}{l}\text { Basement confining } \\
\text { unit }\end{array}$ & $\begin{array}{l}\text { Regional base of the Western Interior Plains aquifer } \\
\text { system. }\end{array}$ \\
\hline
\end{tabular}


SOUTH

DAKOTA

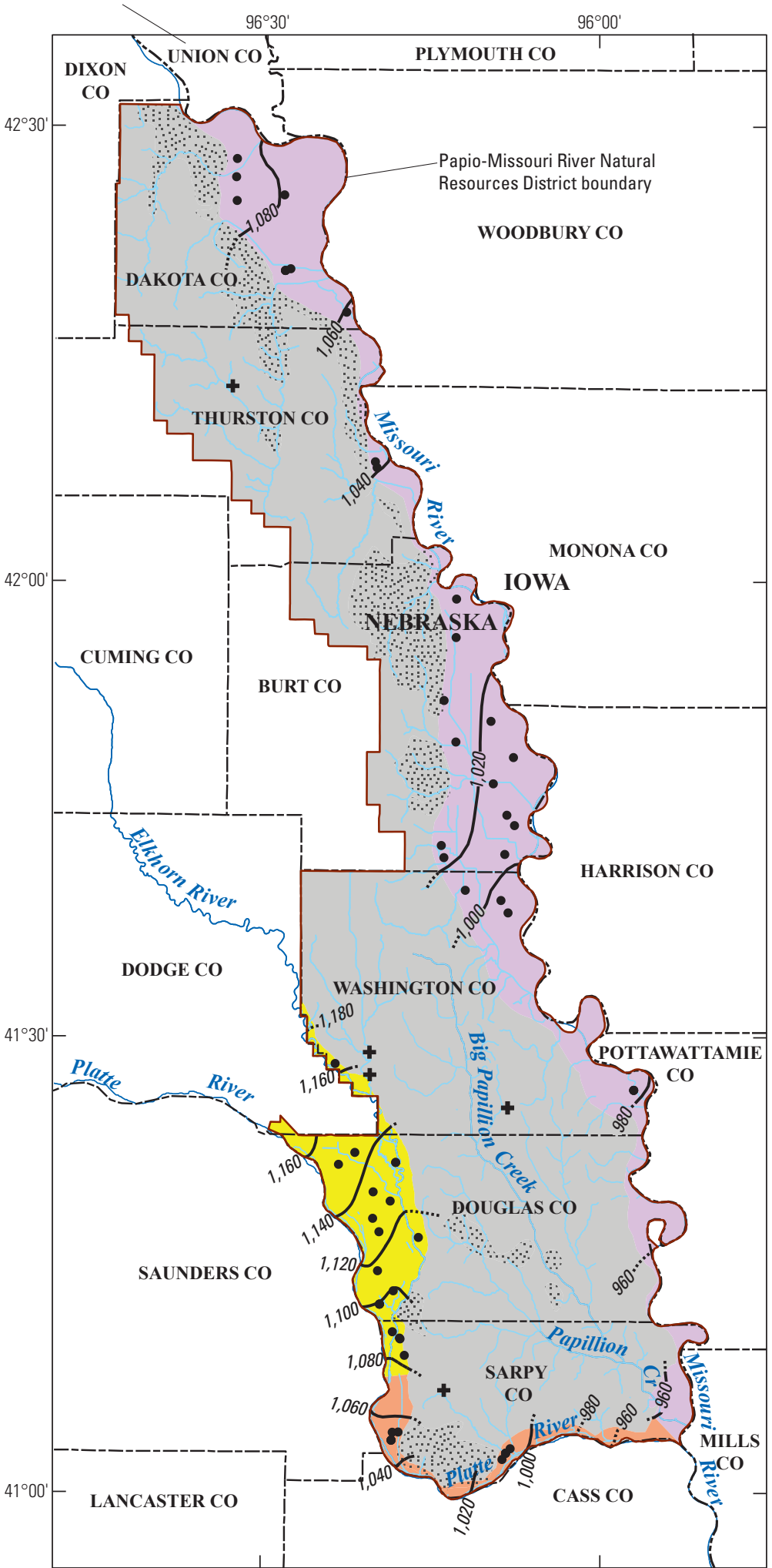

Base from U.S. Geological Survey digital data, 2001, 1:2,000,000

Albers Equal-Area Conic projection

Standard parallels $29^{\circ} 30^{\prime} \mathrm{N}$ and $45^{\circ} 40^{\prime} \mathrm{N}$

Central meridian $97^{\circ} 30^{\prime} \mathrm{W}$

North American Datum of 1983

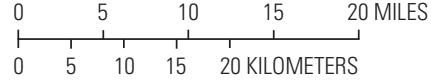

\section{EXPLANATION}

Alluvial aquifer extent-Aquifer extents from Verstraeten and Ellis (1995); water table modified from Nebraska Department of Environmental Quality and University of Nebraska-Lincoln, Conservation and Survey Division (1980a and 1980b) University of Nebraska-Lincoln, Conservation and Survey Division (2010b)

Elkhorn River Valley alluvial aquifer

Platte River Valley alluvial aquifer

Missouri River Valley alluvial aquifer

Upland area alluvial aquifers

Area where deposits of Quaternary age are thin or absent

1,100 - - Water-table contour-Shows altitude of the water table, 2009, for the respective alluvial aquifer. Dashed where inferred. Contour interval 20 feet. Datum is National Geodetic Vertical Datum of 1929 (NGVD 29)

Well screened in the Elkhorn River Valley, Platte River Valley, or Missouri River Valley alluvial aquifers with a 2004-2009 water level that was used to map the altitude of the water table in the respective aquifers

Well screened in an upland alluvial aquifer. The water table was not contoured in the upland alluvial aquifers because of insufficient data

Figure 2. Distribution of Quaternary alluvial aquifers, areas where Quaternary-age deposits are thin or absent, location of wells with water levels used to map the altitude of the water table in the alluvial aquifers in 2009, and generalized altitude of the water table, 2009, in the Elkhorn River Valley, Missouri River Valley, and Platte River Valley alluvial aquifers, PapioMissouri River Natural Resources District, eastern Nebraska. 


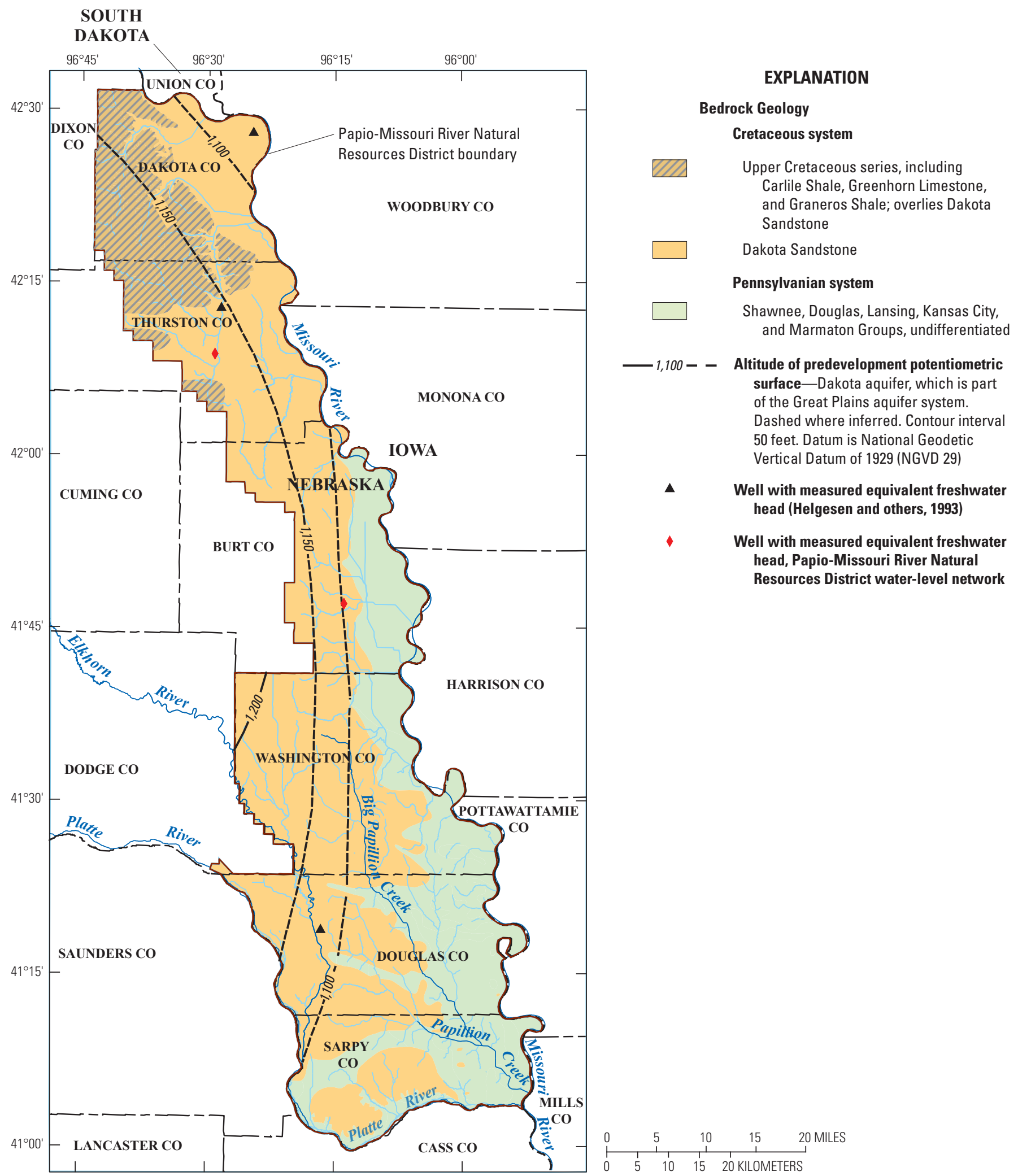

Base from U.S. Geological Survey digital data, 2001, 1:2,000,000 Modified from Helgesen and others, 1993; Albers Equal-Area Conic projection University of Nebraska-Lincoln Standard parallels $29^{\circ} 30^{\prime} \mathrm{N}$ and $45^{\circ} 40^{\prime} \mathrm{N} \quad$ Conservation and Survey Division, 2010b Central meridian $97^{\circ} 30^{\prime} \mathrm{W}$

North American Datum of 1983

Figure 3. Generalized bedrock geology, location of wells screened in the Dakota aquifer with waterlevel data, and altitude of the predevelopment potentiometric surface of the Dakota aquifer, PapioMissouri River Natural Resources District, eastern Nebraska. 
confining system, the Dakota aquifer (part of the Great Plains aquifer system), the late Paleozoic-age Western Interior Plains confining system, the Western Interior Plains aquifer system, and the basement confining unit (Jorgensen and others, 1993; Verstraeten and Ellis, 1995). For this report, because withdrawals from the Dakota aquifer are substantial and withdrawals from the Western Interior Plains aquifer system are minimal (Verstraeten and Ellis, 1995), only the Dakota aquifer is considered as 1 of the 5 principal aquifers in the PMRNRD. Additional discussion on the composition and characteristics of bedrock units in the PMRNRD can be found in Verstraeten and Ellis (1995).

\section{Soils}

The soils in the PMRNRD area are silty, clayey to silty, or sandy (Verstraeten and Ellis, 1995). The estimated waterinfiltration rates range from high in some small areas of bottomland in the Elkhorn, Missouri, and Platte River Valleys to low or very low in the large areas of bottomland along the Missouri River Valley in eastern Burt and Washington Counties (fig. 4; U.S. Department of Agriculture, 2009). These water-infiltration rate estimates assume the soil is not protected by vegetation, is thoroughly wet, and receives precipitation from a storm of long duration.

\section{Land and Water Use}

Agriculture dominates the land use in the PMRNRD area (fig. 5). In 2005, the principal land-use types in the PMRNRD were dry cropland, rangeland, irrigated cropland, and urban land (Center for Advanced Land Management Information Technologies, 2007). From 1991 to 2008, the predominant crops in the PMRNRD were corn, soybeans, and alfalfa (fig. 6) (U.S. Department of Agriculture, 2010). In Burt, Dakota, Thurston, and Washington Counties the number of harvested acres did not change greatly from 1992 to 2008; however, mostly as a result of urbanization, the number of harvested acres in Douglas and Sarpy Counties decreased by about 40 percent and 20 percent, respectively (fig. 6).

Both groundwater and surface water are substantial water sources in the PMRNRD (U.S. Geological Survey, 2010c). In 2005 , total water use for purposes other than those related to generation of power was about 270 million gallons per day. Groundwater was the source for 60 percent of this total, and surface water was the source for the remainder (fig. $7 A$ ). Because this report focuses on groundwater, no further discussion of surface-water use is presented here. Domestic self-suppliers, some public supply for municipal and rural water systems, irrigation, and other uses, such as industrial water users, depend on groundwater sources in and near the PMRNRD area (fig. $7 B$ ). The water for the rural water system in the western part of the PMRNRD in Thurston and Washington
Counties is imported into the PMRNRD from a well field that is west of the PMRNRD boundary.

Groundwater withdrawals increased from 1990 to 2005 in all the counties of the PMRNRD, except for Sarpy County (fig. 7B). The increases in groundwater withdrawals in Burt, Dakota, Dodge, Thurston, and Washington Counties were primarily for irrigation use. The increases in groundwater withdrawals in Douglas County were primarily for domestic, self-supplied, and public-supply use. The decreases in groundwater withdrawals in Sarpy County reflect decreases in withdrawals for public supply, domestic self-supply, and other uses, including for livestock and industrial use (U.S. Geological Survey, 2010c). Groundwater withdrawals in Douglas County during 2010 will likely be greater than withdrawals in 2005 because a new municipal well field with wells screened in the Elkhorn River Valley or Platte River Valley alluvial aquifer was completed and placed into production in July 2008 (http://www.mudomaha.com/plattewest/timeline.html).

\section{Agricultural Chemical Use}

In the PMRNRD, agricultural chemicals, typically fertilizers and pesticides, commonly are applied to the land surface in agricultural and urban settings to increase crop yield, promote plant and lawn growth, or control competing vegetation, insects, and fungi. Many of these chemicals can move beneath the plant root zones and into groundwater. This report refers to chemicals in groundwater that are derived at least partly from commercial fertilizer or manure as nutrients - ammonia, nitrate, nitrite, and orthophosphate. In the PMRNRD, the estimated commercial fertilizer inputs for nitrogen in 2001, normalized by total county area, ranged from 46 pounds per acre per year [(lb/acre)/yr] in Sarpy and Washington Counties to 72 (lb/acre)/yr in Douglas County. The estimated commercial fertilizer input for phosphorus in 2001, normalized by total county area, ranged from 6 (lb/acre)/yr in Sarpy and Washington Counties to 10 (lb/acre)/yr in Douglas County (table 2; Ruddy and others, 2006).

In 2005 , the 10 most commonly applied pesticides in the PMRNRD, in decreasing order of estimated use, were atrazine, glyphosate, acetochlor, S-metolachlor, chlorpyrifos, 2,4-D, alachlor, pendimethalin, dimethenamid, and dicamba (table 3). Nine of these pesticides are herbicides; the remaining pesticide, chlorpyrifos, is an insecticide. In 2005, the total number of acres treated with atrazine or glyphosate in the PMRNRD was estimated to be 595,000 ; about 80 percent of these acres are in Burt, Dakota, Thurston, and Washington Counties (table 3 ).

Because pesticide use has changed since 2005, county extension agents were contacted to ascertain current (2010) pesticide use in the PMRNRD. County extension agents reported that glyphosate currently (2010) is the most widely used pesticide, but atrazine still is used on agricultural lands. Acetochlor still is used but usually in a mixture of several pesticides; dicamba and 2,4-D also continue to be used. Use 


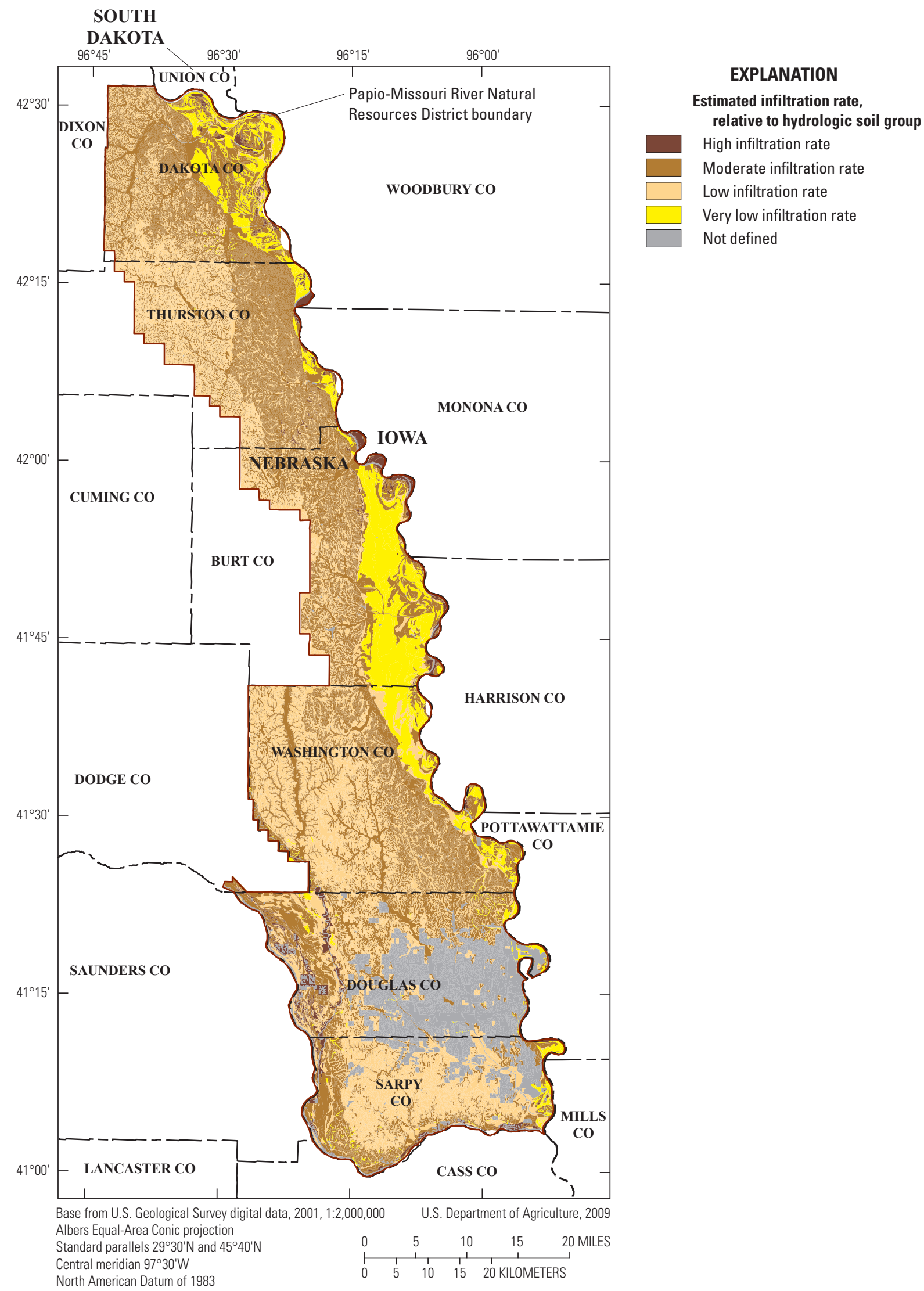

Figure 4. Distribution of estimated infiltration rates, by hydrologic soil group, Papio-Missouri River Natural Resources District, eastern Nebraska. 


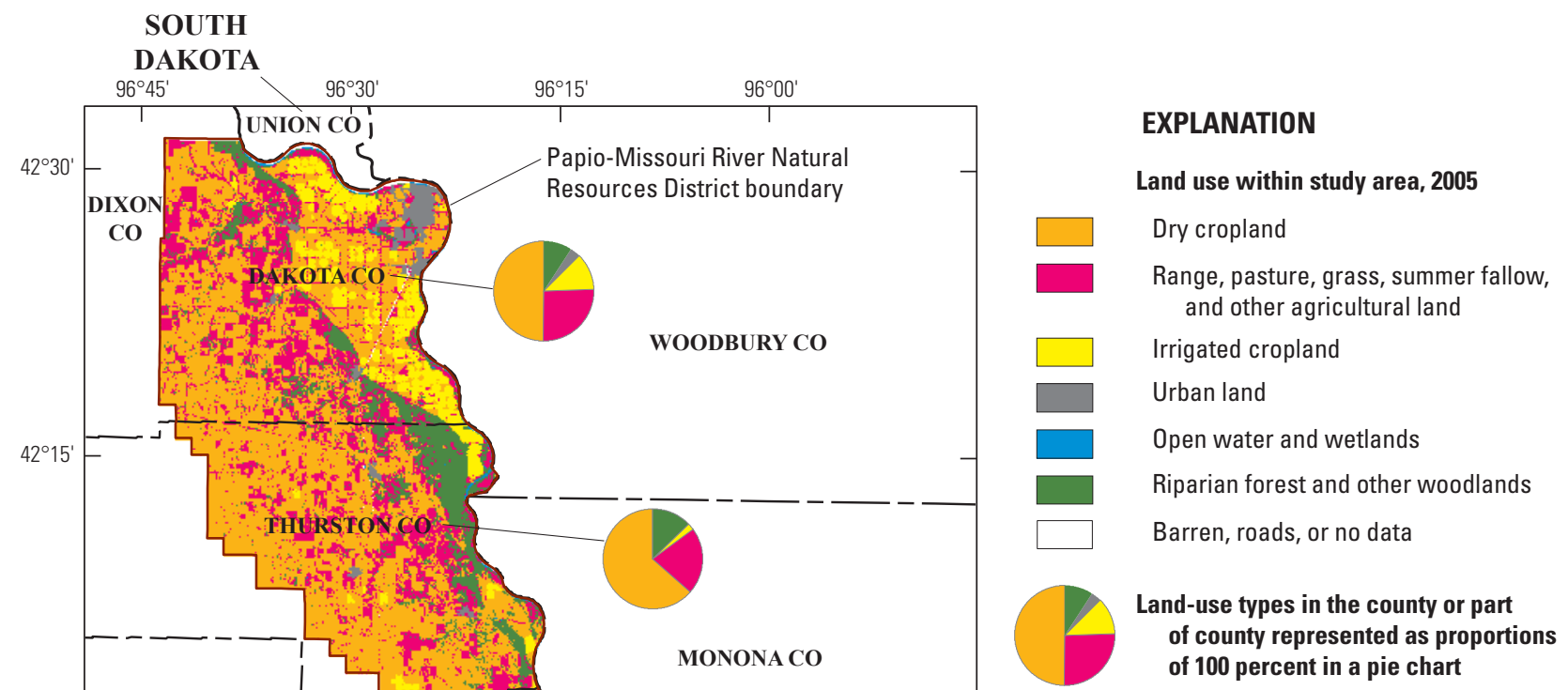

HARRISON CO

DODGE CO

IOWA
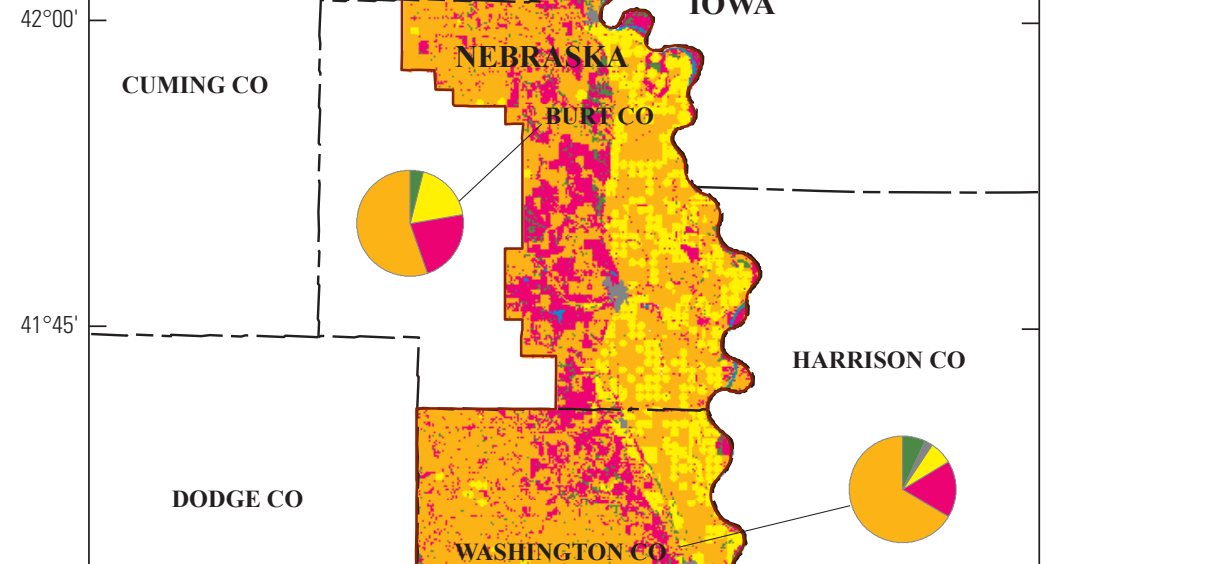

$\overline{\mathrm{ATTAMIE}}$

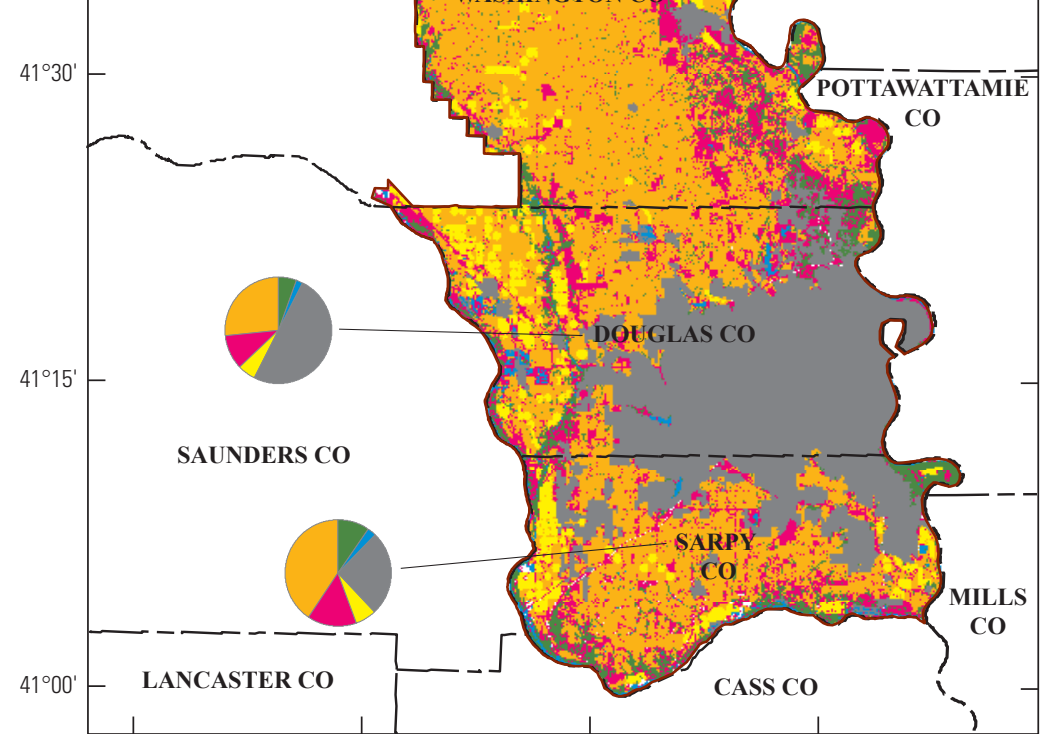

Base from U.S. Geological Survey digital data, 2001, 1:2,000,000 Center for Advanced Land Management Albers Equal-Area Conic projection

Standard parallels $29^{\circ} 30^{\prime} \mathrm{N}$ and $45^{\circ} 40^{\prime} \mathrm{N}$

Central meridian $97^{\circ} 30^{\prime} \mathrm{W}$

North American Datum of 1983

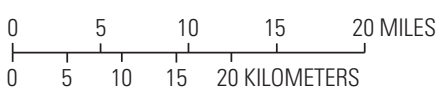

Figure 5. Distribution of primary land-use types and graphs showing proportion of land-use types, by county or part of county, PapioMissouri River Natural Resources District, eastern Nebraska, 2005. 


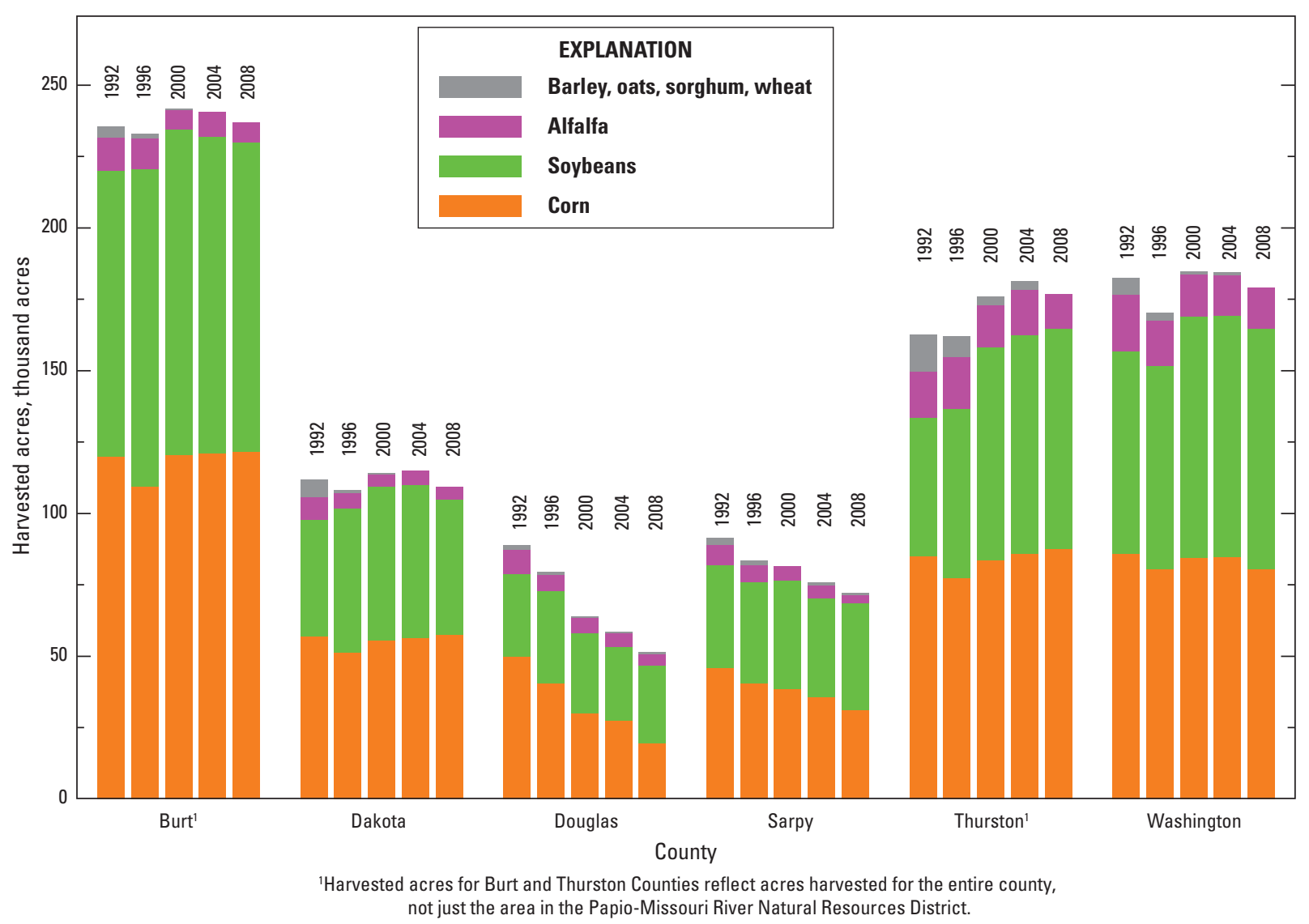

Figure 6. Harvested acres, by crop and county, for all counties except Dodge County, Papio-Missouri River Natural Resources District, eastern Nebraska, 1992, 1996, 2000, 2004, and 2008 (Modified from U.S. Department of Agriculture, 2010).

of organophosphate insecticides, such as chlorpyrifos, has decreased, although chlorpyrifos still is used, for example, to control aphids in wet years. Use of pyrethroid-based insecticides (typical active ingredient: bifenthrin; typical trade names: Ambush and Pounce) has increased since 2002 (John A. Wilson, Burt County extension agent, written commun., July 2010; Dennis Ferraro, Douglas and Sarpy County extension agent, oral commun., July 2010; Keith Jarvi, Dakota, Thurston, and Dixon County extension agent, oral commun., July 2010; Steve Tonn, Washington County extension agent, oral commun., July 2010).

\section{Methods of Investigation}

This section describes the installation in 1999 of wells in well nests used in this study; processes used by USGS to select the network wells (from 1992 to 2009) and wells in well nests (from 1999 to 2009) used for groundwater sampling; and methods used by USGS for groundwater-sample collection and documentation, chemical analysis, and quality assurance and quality control for the PMRNRD study from 1992 to 2009. This section also describes data treatment and analysis used in this report. Analytical results from 1992 to 2009, presented in this report, were evaluated by comparing the results to Federal drinking-water standards that are applied to treated drinking water and to State regulations for groundwater (U.S. Environmental Protection Agency, 2009a; Nebraska Department of Environmental Quality, 2006). The data presented in this report characterize the quality of untreated groundwater resources within the study unit, not the treated drinking water delivered to consumers by municipal or rural water systems.

\section{Well Nest Installation, 1999}

In 1999, the USGS oversaw the installation of 26 wells in 9 well nests in the PMRNRD. Each well nest was constructed with 2 to 3 short-screened ( 5 to $10 \mathrm{ft}$ ) monitoring wells installed in individual boreholes. A test hole drilled to the base of the aquifer was used to obtain lithologic cuttings to determine the number and depth of the wells in the nest. If sufficient aquifer thickness existed, three wells were installed in the well nest - a shallow well with a 10-ft screen located near the water table, a medium-depth well with a 5 -ft screen located approximately in the middle of the aquifer, and a deep well with a 5-ft screen located near the base of the aquifer. If aquifer thickness did not allow for 3 wells, only 2 

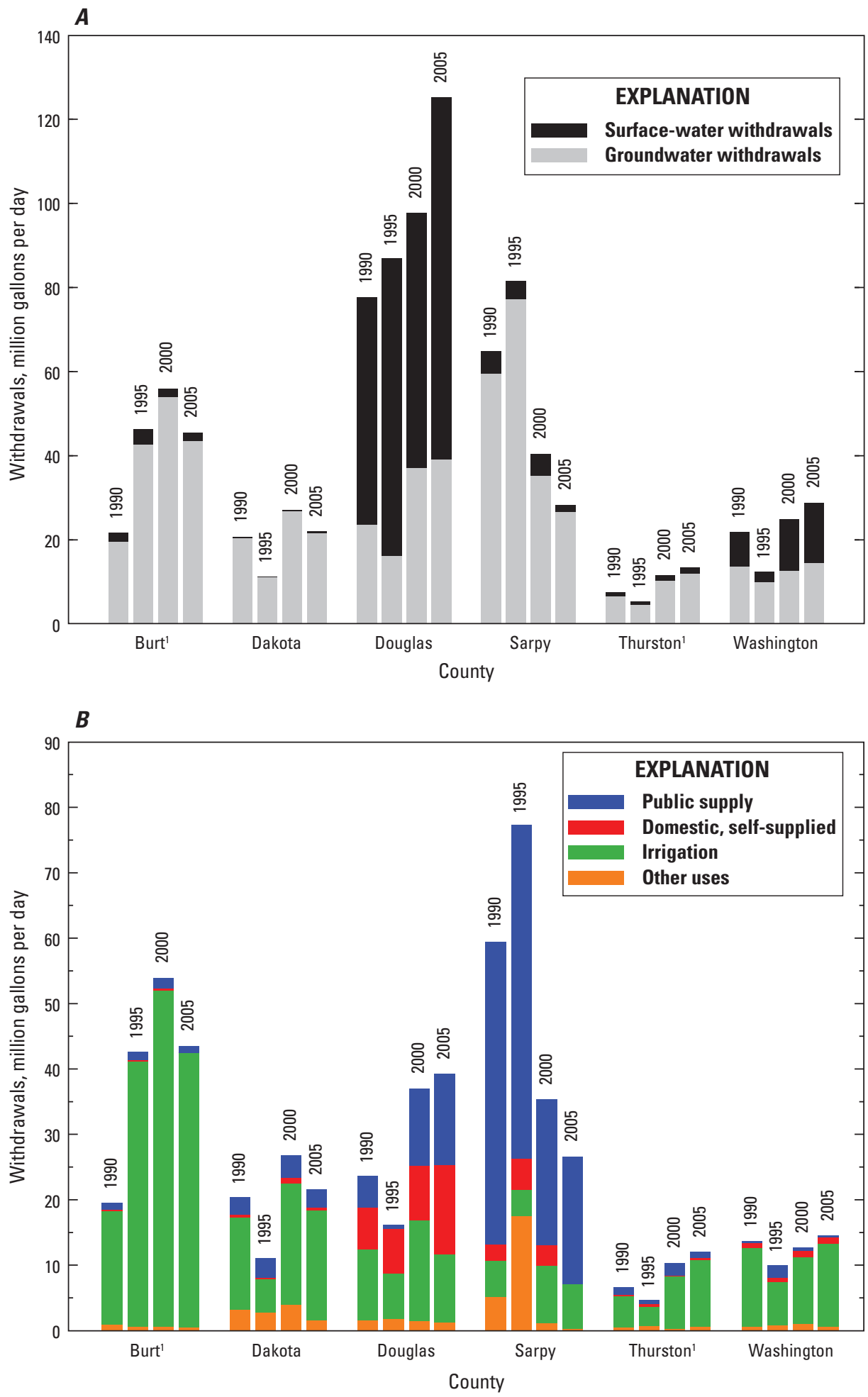

'Withdrawal data for Burt and Thurston Counties reflect withdrawal amounts for the entire county, not just the area in the Papio-Missouri River Natural Resources District

Figure 7. $A$, total groundwater and surface-water withdrawals for all uses except those related to generation of power and $B$, groundwater withdrawals by type of use except those related to generation of power, by county, for all counties except Dodge County, Papio-Missouri River Natural Resources District, eastern Nebraska, 1990, 1995, 2000, and 2005 (Modified from U.S. Geological Survey, 2010c). 
Table 2. Estimated nonpoint-source inputs of nitrogen and phosphorus, by county, Papio-Missouri River Natural Resources District, eastern Nebraska, 2001.

[Input estimates from Ruddy and others (2006)]

\begin{tabular}{lcccccc}
\hline \multirow{2}{*}{$\begin{array}{c}\text { Nitrogen or } \\
\text { phosphorous source }\end{array}$} & \multicolumn{6}{c}{ Total nitrogen and phosphorus inputs divided by total county area, } \\
in pounds per acre per year
\end{tabular}

${ }^{1}$ About 58 percent of Burt County, 98 percent of Dakota County, and 65 percent of Thurston County are within the boundary of the Papio-Missouri River Natural Resources District.

Table 3. Ten most commonly applied pesticides, estimated treated area, and average pesticide application rate, by county, Papio-Missouri River Natural Resources District, eastern Nebraska, 2005.

[Pesticide application rates in 2002 by crop (CropLife Foundation, 2010) applied to 2005 crop acreage (Center for Advanced Land Management Information Technologies, 2007)]

\begin{tabular}{|c|c|c|c|c|c|c|c|c|c|}
\hline \multirow{2}{*}{ Pesticide } & \multirow{2}{*}{$\begin{array}{l}\text { Pesticide } \\
\text { type }\end{array}$} & \multicolumn{7}{|c|}{$\begin{array}{l}\text { Estimated treated area, in thousand acres, in decreasing order by } \\
\text { total estimated treated acres }\end{array}$} & \multirow{2}{*}{$\begin{array}{l}\text { Average pesticide } \\
\text { application rate } \\
\text { (pounds of active } \\
\text { ingredient appliec } \\
\text { per treated acre) }\end{array}$} \\
\hline & & $\begin{array}{c}\text { Burt } \\
\text { County }\end{array}$ & $\begin{array}{l}\text { Dakota } \\
\text { County }\end{array}$ & $\begin{array}{l}\text { Douglas } \\
\text { County }\end{array}$ & $\begin{array}{l}\text { Sarpy } \\
\text { County }\end{array}$ & $\begin{array}{l}\text { Thurston } \\
\text { County }\end{array}$ & $\begin{array}{l}\text { Washington } \\
\text { County }\end{array}$ & Total & \\
\hline Atrazine & Herbicide & 60.9 & 48.9 & 34.3 & 30.1 & 50.0 & 83.1 & 307.3 & 0.9 \\
\hline Glyphosate & Herbicide & 59.9 & 44.9 & 27.7 & 34.6 & 41.2 & 79.0 & 287.3 & 1.0 \\
\hline Acetochlor & Herbicide & 16.3 & 13.0 & 9.2 & 8.0 & 13.3 & 22.2 & 82.0 & 1.6 \\
\hline S-Metolachlor & Herbicide & 16.5 & 13.2 & 9.1 & 8.4 & 13.2 & 22.5 & 82.9 & .9 \\
\hline Chlorpyrifos & Insecticide & 9.4 & 7.1 & 4.6 & 5.2 & 6.7 & 12.5 & 45.5 & .6 \\
\hline $2,4-\mathrm{D}$ & Herbicide & 6.3 & 5.9 & 3.7 & 3.4 & 5.4 & 7.5 & 32.2 & .8 \\
\hline Alachlor & Herbicide & 3.2 & 2.5 & 1.6 & 1.8 & 2.4 & 4.3 & 15.8 & 1.5 \\
\hline Pendimethalin & Herbicide & 5.3 & 4.0 & 2.4 & 3.1 & 3.6 & 7.0 & 25.4 & .9 \\
\hline Dimethenamid & Herbicide & 4.2 & 3.4 & 2.4 & 2.1 & 3.5 & 5.8 & 21.4 & .8 \\
\hline Dicamba & Herbicide & 8.7 & 7.4 & 4.9 & 4.4 & 7.2 & 11.4 & 44.0 & .3 \\
\hline
\end{tabular}

${ }^{1}$ Estimated treated acres are for the area of the county in the Papio-Missouri River Natural Resources District and not for the entire county. 
wells were installed in the nest-a shallow well with a $10-\mathrm{ft}$ screen located near the water table and a deep well with a $5-\mathrm{ft}$ screen located near the base of the aquifer. Three wells were installed in the well nests in or near Venice, Blair, Tekamah, Homer, Walthill, Springfield, Fort Calhoun, and Ashland, Nebr. [Ashland, Nebr., which is not shown in fig.1, is located about 11 miles (mi) southwest of Gretna, Nebr.]; 2 wells were installed in the well nest near Elkhorn, Nebr.

\section{Well Selection}

In 1992, Verstraeten and Ellis (1995) sampled 58 existing wells in the PMRNRD; from 1994 to 2009 an additional 133 existing wells were sampled. For this report, these 191 wells are termed "network" wells; the word "network" is used to distinguish these wells from the dedicated monitoring well clusters that were installed in 1999 and are hereafter referred to as "wells in well nests."

\section{Well Selection, 1992 to 1994}

In 1992, Verstraeten and Ellis (1995) selected the network wells using a random, spatially stratified approach by aquifer from a set of available wells with specific well-construction information (such as depth and screened interval). Each selected well was screened in only 1 of the 5 principal aquifers of the PMRNRD. Verstraeten and Ellis (1995) also sampled three additional wells (D-007, M-005, and M-007) that are not discussed in this report because of current uncertainty regarding the location of the wells or construction information for the wells (refer to fig. 11 in Verstraeten and Ellis, 1995, for the approximate location of these excluded wells). In addition, the field identifiers for two of the wells sampled in 1992 have been renamed in this report; the renamed wells are D-005D, which was called D-005 by Verstraeten and Ellis (1995), and M-009A, which was called M-009 by Verstraeten and Ellis (1995).

In 1994, the USGS selected a total of 36 wells for sampling. Six of these 36 wells (D-009, P-005, U-002, U-005, U-009, and U-011) were sampled during the Verstraeten and Ellis (1995) study. The remaining 30 wells that had not been previously sampled were added to the PMRNRD set of network wells.

\section{Well Selection, 1995 to 2009}

From 1995 to 2009, a subset of the network wells was selected manually from the set of existing network wells with preference given to wells with the greatest number of previous determinations of nitrate and to wells that would produce a well-distributed spatial coverage of the aquifer areas in the PMRNRD. Additional registered wells, primarily production (irrigation or public supply) and domestic wells (Nebraska Department of Natural Resources, 2010), were added to the set of network wells if an existing network well was no longer available for sampling or there were areas where the designated aquifer(s) lacked an existing network well. Securing the land owner's permission to sample also was a requirement for continued inclusion in the set of network wells selected for sampling.

From 1995 to 1998, the USGS sampled between 17 and 67 wells each year; 47 of these wells had not been previously sampled and were added to the PMRNRD set of network wells. In 1995 to 1997, wells from all aquifers were sampled; in 1998, only wells screened in the Missouri River Valley alluvial aquifer were sampled.

From 1999 to 2009, the USGS continued or began collecting samples in the network wells and wells in well nests. The network wells generally were sampled, by aquifer, using a rotating 3-year schedule; the number of network wells sampled each year ranged from 17 to 40 . Fifty-six of these wells had not been previously sampled and were added to the PMRNRD set of network wells. The 26 wells in 9 well nests were sampled on varying schedules from 1999 to 2009- every 2 months to annually.

\section{Well Identification}

Network wells were assigned a unique USGS station identifier and a field identifier when they were (1) first sampled or (2) installed (that is, for the wells in well nests). The field identifier format for network wells is alphabetic aquifer code, dash, number, and (optional) letter; the field identifier format for wells in nests is alphabetic aquifer code, dash, nest identifier, and number. The aquifer codes used in the field identifiers are D (Dakota aquifer), E (Elkhorn River Valley alluvial aquifer), M (Missouri River Valley alluvial aquifer), P (Platte River Valley alluvial aquifer), and U (upland area alluvial aquifers). The nest identifiers used in the field identifiers are A (Ashland), B (Blair Airport), BC (Boyers Chute), EC (Elkhorn Crossing), H (Homer), S (Springfield), $\mathrm{T}$ (Tekamah), V (Venice), and W (Walthill). The locations of the network wells and wells in well nests sampled from 1992 to 2009 are shown in figure 8 with the field identifiers. Available construction information for network wells and well nests is listed in appendix 1.

\section{Sample Collection, 1992 to 2009}

From 1992 to 2009, samples were collected generally in accordance with the protocols established by the USGS National Field Manual (U.S. Geological Survey, variously dated). These sampling protocols ensure that a representative sample of groundwater is collected at each site and that the samples are collected and handled in a way that minimizes contamination.

Many network wells in the PMRNRD are irrigation wells that typically operate periodically during summer to fall. Consequently, samples from network wells used for irrigation, which typically were collected only when the pumps 


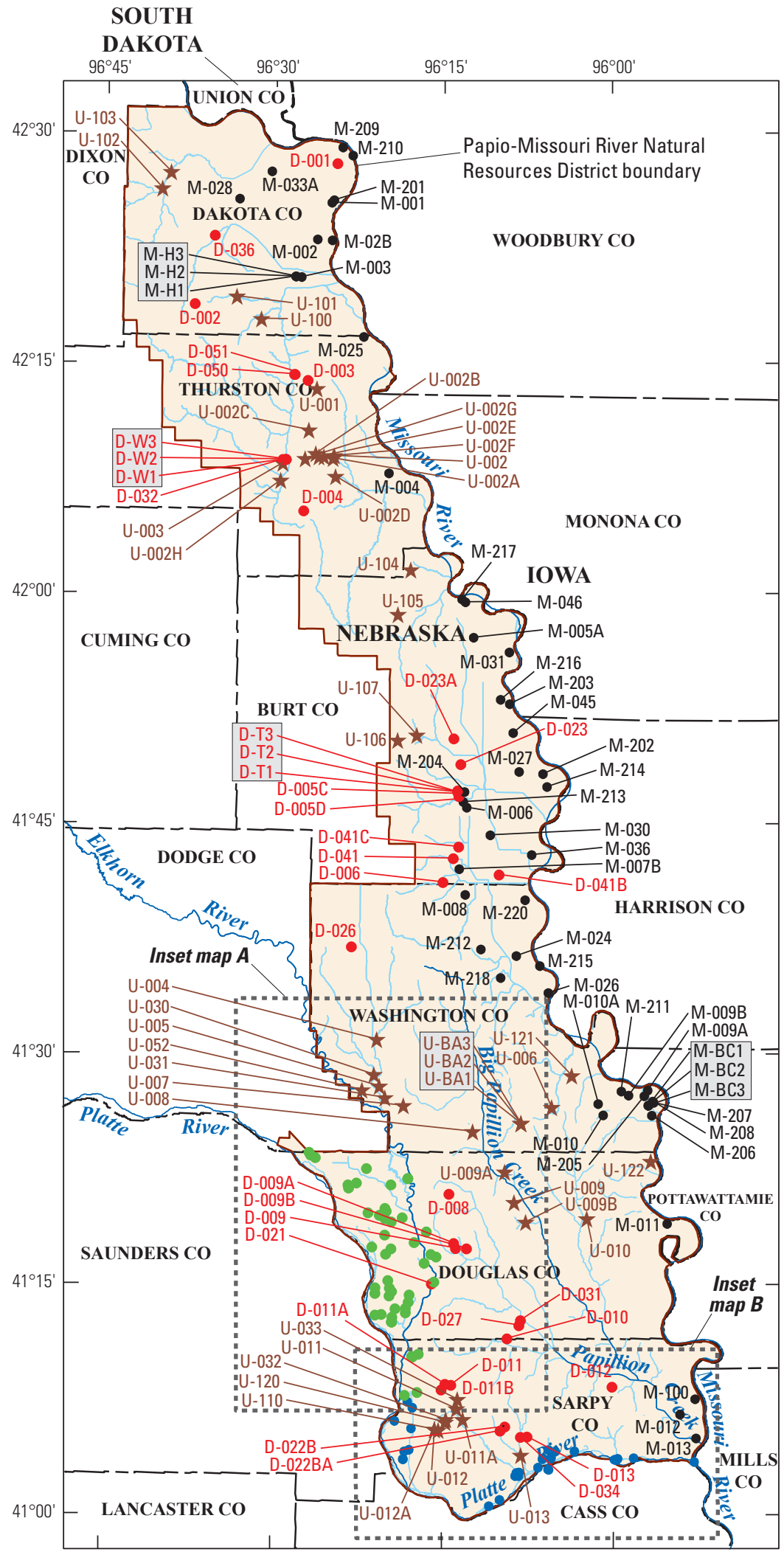

Base from U.S. Geological Survey digital data, 2001, 1:2,000,000

Albers Equal-Area Conic projection

Standard parallels $29^{\circ} 30^{\prime} \mathrm{N}$ and $45^{\circ} 40^{\prime} \mathrm{N}$

Central meridian $97^{\circ} 30^{\prime} \mathrm{W}$

North American Datum of 1983

\section{EXPLANATION}

Sampled wells and field identifiers

D-036 Well screened in the Dakota aquifer

- Well screened in the Elkhorn River Valley alluvial aquifer (see inset map $A$ for identifiers)

M-004 Well screened in the Missouri River Valley alluvial aquifer

- Well screened in the Platte River Valley alluvial aquifer (see inset map $B$ for identifiers)

U-103 $\star$ Well screened in an upland area alluvial aquifer $\mathrm{M}-\mathrm{BC} 1$

$M-B C 27$ Set of wells in a well nest

$\mathrm{M}-\mathrm{BC} 3$ 


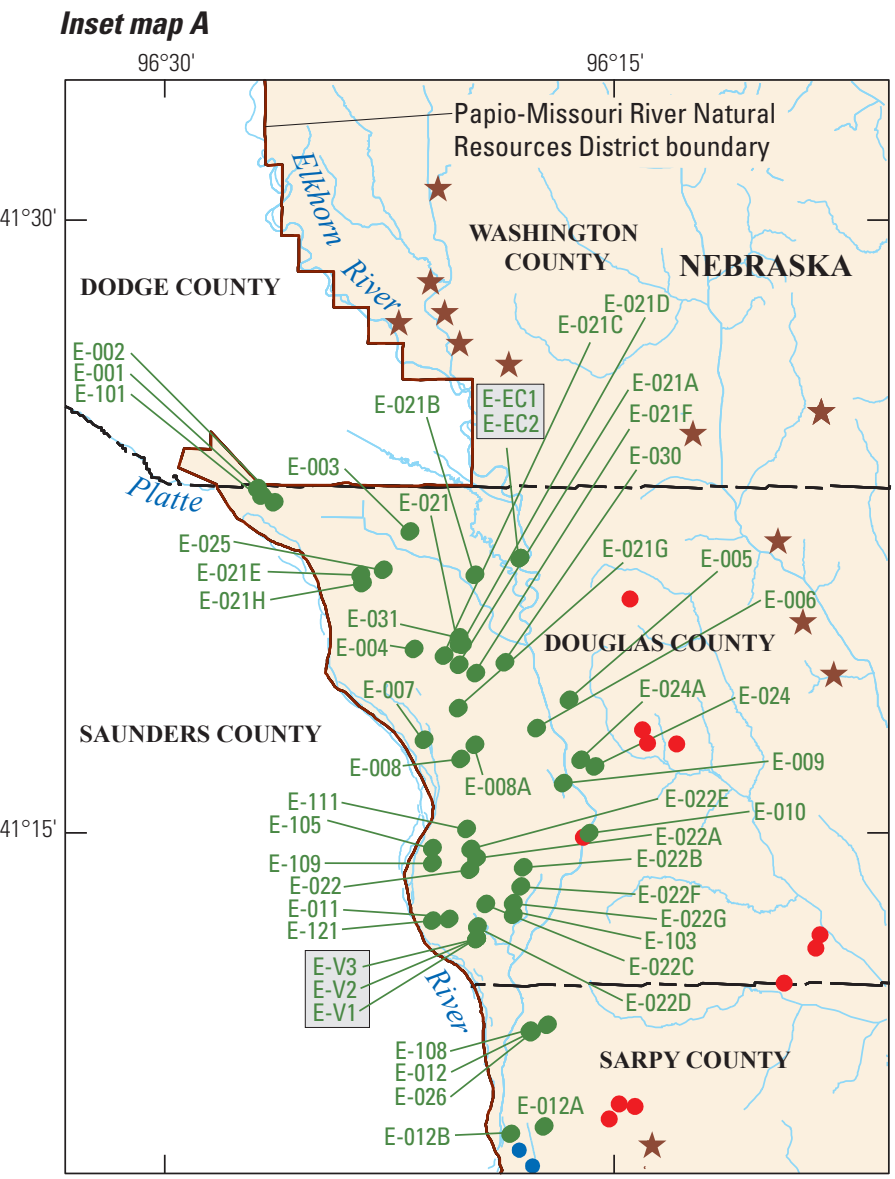

\section{EXPLANATION \\ [Inset maps $A$ and $B$ ]}

\section{Sampled wells and field identifiers}

- Well screened in the Dakota aquifer

E-008A Well screened in the Elkhorn River Valley alluvial aquifer (see inset map $A$ for identifiers)

- Well screened in the Missouri River Valley alluvial aquifer

P-S3 Well screened in the Platte River Valley alluvial aquifer (see inset map $B$ for identifiers)

$\star \quad$ Well screened in an upland area alluvial aquifer

Inset map B

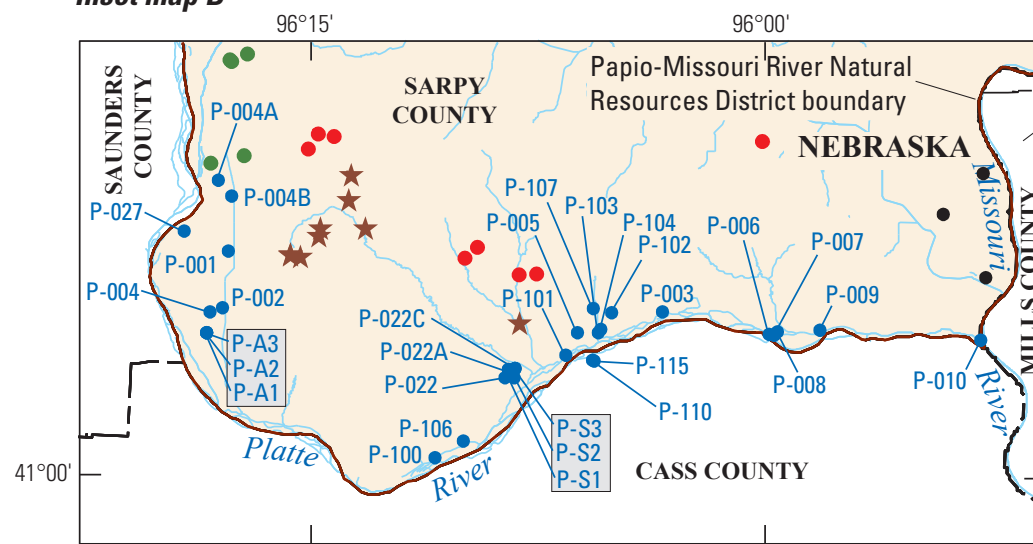

IOWA

Base from U.S. Geological Survey digital data, 2001, 1:2,000,000

Albers Equal-Area Conic projection

Standard parallels $29^{\circ} 30^{\prime} \mathrm{N}$ and $45^{\circ} 40^{\prime} \mathrm{N}$

Central meridian $97^{\circ} 30^{\prime} \mathrm{W}$

North American Datum of 1983

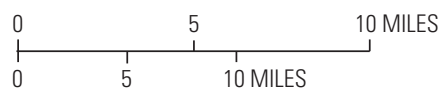

Figure 8. Location of sampled wells, Papio-Missouri River Natural Resources District, eastern Nebraska, 1992-2009.-Continued 
were in operation for irrigation, were collected in summer to fall. With respect to wells in well nests, sampling occurred at regular intervals throughout the year because each well could be sampled easily at any time. Generally, wells in well nests were sampled more than twice per year. If wells in well nests were sampled twice a year, sampling generally occurred in the late winter or spring and during summer to fall. If sampling occurred once a year, samples generally were collected in either late winter or spring, or during summer to fall.

Dedicated pumps, which were installed in the network wells and in the wells in well nests, were used to obtain all water samples. Water was collected from each well as close to the pump as possible and prior to any treatment of the water. Observations about the well's integrity, the sampling location, and any point sources of contamination were made for all wells. Sampling protocol differed slightly for network wells and the wells in well nests.

Prior to sampling wells in well nests, the water level and well depth were measured to the nearest $0.01 \mathrm{ft}$ using a graduated steel tape; in addition, the pumping rate was measured manually using a 5-gallon bucket. When sampling network wells, water level, well depth, and pumping rate were not measured prior to sampling. In the network wells, water level and well depth were not measured because the network wells generally were in operation prior to sampling, and pumping rate was not measured because the discharge amount generally is greater than the amount that can be manually measured using a bucket. When sampling network wells and wells in well nests, measurements of specific conductance, $\mathrm{pH}$, water temperature, and dissolved oxygen generally were made using a flow-through chamber until measurements stabilized as per protocol and at least three well-casing volumes of water had been withdrawn. For network wells that are domestic wells with a supply tank located between the pump and the sampling point, the well was pumped until the supply tank likely had been flushed (U.S. Geological Survey, variously dated).

For all wells, collection, processing, and preservation of all environmental and QC samples (excluding equipment blanks and reference samples) were completed on site (table 4). Often, when a well, network or nested, was sampled only for nitrate or nutrients and pesticides, samples were collected in a Teflon ${ }^{\circledR}$ container at the faucet, carried to the sampling vehicle (usually a mobile laboratory), and processed. Sample processing in these situations involved using a peristaltic pump to transfer the water from the Teflon ${ }^{\circledR}$ container through the filter, if necessary, into the sample bottle. The samples to be analyzed for trace elements, volatile organic compounds (VOCs), and explosives and the remaining samples to be analyzed for nutrients and pesticides were collected using Teflon ${ }^{\circledR}$ tubing to convey the well's discharge into the mobile laboratory for sample processing (U.S. Geological Survey, variously dated).

For analyses that required filtered water, samples underwent filtration during sample collection using a 0.45 -micrometer $(\mu \mathrm{m})$ filter or a nominal $0.7-\mu \mathrm{m}$ glass fiber filter. Water samples for ${ }^{222}$ radon analysis were collected using a syringe method. The samples for chlorofluorocarbons (CFCs) and dissolved gases analyses required specialized sampling equipment or procedures to ensure the groundwater samples did not come in contact with the atmosphere (Busenberg and Plummer, 1992; U.S. Geological Survey, 2006a, 2009a, variously dated).

Field equipment was decontaminated and cleaned immediately following sample collection. Samples generally were sent to the appropriate analytical laboratory within 2 days of sample collection. Pesticide samples that were screened for triazines (a group of related chemicals that includes atrazine) or metolachlor using enzyme-linked immunosorbent assay (ELISA) screening kits generally were held in the cooler at the USGS office in Lincoln, Nebr., for 2 to 6 days to allow time to split and analyze the sample; when detections were identified, a subset of the sample was sent to the USGS National Water Quality Laboratory (NWQL) in Denver, Colo., or the USGS Organic Research Laboratory (OGRL), Lawrence, Kans., for pesticide analysis. Samples needing to be chilled were maintained on ice in coolers with the intended maximum temperature of $4^{\circ} \mathrm{C}$ from sample collection until arrival at the analytical laboratory.

\section{Sample Analysis and Reporting}

Water samples were analyzed at USGS and other laboratories using analytical methods approved by USEPA or USGS (table 4). For the reader's convenience, results from water samples collected from 1992 to 2009 are available in appendix 2, on the USGS National Water Information System (NWIS) web site (U.S. Geological Survey, 2010a), and in the USGS annual reports (Boohar and others, 1993, 1995, and 1996; Boohar and Walczyk, 1997 and 1998; Boohar, 1999 and 2000; Engel, 2001; Hitch and others, 2002, 2003, 2004, 2005; U.S. Geological Survey, 2006b, 2007, 2008, 2009b, and $2010 b)$. In the USGS annual reports, the results from water samples are reported by water year. A water year is defined as the 12-month period October 1, for any given year through September 30, of the following year. The water year is designated by the calendar year in which it ends and which includes 9 of the 12 months. That is, the 12-month period ending September 30, 2009 is called the " 2009 " water year.

For this report, the samples selected for analysis were the latest available results in the designated time period for the network wells and for one randomly selected well in each of the well nests. The randomly selected wells in the well nests were E-EC1, E-V1, D-W3, D-T2, M-BC1, M-H1, P-A1, P-S1, and U-BA2.

Delta $(\delta)$ notation is used in this report to present the results of isotopic analysis of ${ }^{15} \mathrm{~N} /{ }^{14} \mathrm{~N}$ and ${ }^{18} \mathrm{O} /{ }^{16} \mathrm{O}$ ratios in nitrate and ${ }^{15} \mathrm{~N} /{ }^{14} \mathrm{~N}$ ratio in atmospheric nitrogen gas $\left(\mathrm{N}_{2}\right)$. Values of $\delta^{15} \mathrm{~N}$ in nitrate and in dissolved $\mathrm{N}_{2}$ are reported in per mil relative to $\mathrm{N}_{2}$ in the atmospheric air standard (AIR); values of $\delta^{18} \mathrm{O}$ in nitrate are reported in per mil relative to the 
Table 4. Laboratory analytical methods and field preservation procedures for water-quality constituents, Papio-Missouri River Natural Resources District, eastern Nebraska, 1992-2009.

[ $\mu \mathrm{m}$, micrometer; CFCs, chlorofluorocarbons; USGS, U.S. Geological Survey; RCFC, Reston Chlorofluorocarbon Laboratory, Reston, Va.; GC, gas chromotography; mL, milliliter; TestAmerica, TestAmerica Laboratory, Denver, Colo.; USEPA, U.S. Environmental Protection Agency; ${ }^{\circ} \mathrm{C}$, degrees Celsius; NWQL, National Water Quality Laboratory, Denver, Colo.; RSIL, Reston Stable Isotope Laboratory, Reston, Va.; GC/IRMS, gas chromatography/isotope-ratio mass spectrometer; OGRL, Organic Geochemistry Research Laboratory, Lawrence, Kans.; GC/MS, gas chromatography/mass spectrometry; HPLC/MS, highperformance liquid chromatography/mass spectrometry; NEWSC, Nebraska Water Science Center, Lincoln, Nebr.; <, less than]

\begin{tabular}{|c|c|c|c|c|c|}
\hline Constituent or constituent group & Analyzing laboratory & Analytical method(s) & Reference(s), listed in publication order & Field preservation procedure(s) & $\begin{array}{l}\text { Years samples } \\
\text { collected }\end{array}$ \\
\hline Physical properties & Analyzed onsite & Various methods & U.S. Geological Survey, variously dated & None. & $1992-2009$ \\
\hline Carbonate alkalinity & Analyzed onsite & Inflection point titration & U.S. Geological Survey, variously dated & Filter through $0.45-\mu \mathrm{m}$ filter. & 1992-2009 \\
\hline CFCs & USGS RCFC & $\begin{array}{l}\text { Purge-and-trap GC with an } \\
\text { electron capture detector }\end{array}$ & $\begin{array}{l}\text { Busenberg and Plummer, 1992; } \\
\text { U.S. Geological Survey, 2009a }\end{array}$ & $\begin{array}{l}\text { Fill } 62-\mathrm{mL} \text { borosilicate ampule; fuse ampule } \\
\text { closed with a gas torch. }\end{array}$ & 2000 \\
\hline Dissolved gases & USGS RCFC & $\begin{array}{l}\text { GC with flame ionization } \\
\text { or thermal conductivity } \\
\text { detection }\end{array}$ & U.S. Geological Survey, 2006a & $\begin{array}{l}\text { Fill } 150 \text {-mL septum bottle with sample; in } \\
2004 \text { only, add two potassium hydroxide } \\
\text { pellets; chill and maintain at temperature of } \\
\text { groundwater. }\end{array}$ & 2000,2004 \\
\hline Explosives & TestAmerica & $\begin{array}{l}\text { USEPA methods } 8330 \text { (also } \\
\text { known as } 8330 \mathrm{a} \text { ) and } 8321 \mathrm{a} \\
\text { (modified from } 8321 \mathrm{~b} \text { ) }\end{array}$ & U.S. Environmental Protection Agency, 1986 & Chill and maintain at $4^{\circ} \mathrm{C}$ & $2007-2009$ \\
\hline $\begin{array}{l}\text { Nutrients (nitrogen and } \\
\text { phosphorus compounds) }\end{array}$ & USGS NWQL & Various methods & Fishman, 1993 & $\begin{array}{l}\text { Filter through } 0.45-\mu \mathrm{m} \text { filter, chill, and } \\
\text { maintain at } 4^{\circ} \mathrm{C} \text {. }\end{array}$ & $1992-2009$ \\
\hline $\begin{array}{l}\text { Nitrogen and oxygen isotopes } \\
\text { in nitrate }\end{array}$ & USGS RSIL & GC/IRMS & $\begin{array}{l}\text { Sigman and others, 2001; Casciotti and others, } \\
2002\end{array}$ & Filter, chill, and maintain at $4^{\circ} \mathrm{C}$. & 2004 \\
\hline $\begin{array}{l}\text { Nitrogen isotopes in dissolved } \\
\text { nitrogen gas }\end{array}$ & USGS RSIL & GC/IRMS & $\begin{array}{l}\text { Casciotti and others, 2002; Böhlke and } \\
\text { others, 2003; Révész and Casciotti, } 2007\end{array}$ & Same as dissolved gases procedure (above). & 2004 \\
\hline $\begin{array}{l}\text { Pesticides and pesticide } \\
\text { degradates }\end{array}$ & $\begin{array}{l}\text { USGS NWQL and } \\
\text { USGS OGRL }\end{array}$ & $\begin{array}{l}\text { C-18 solid-phase extraction } \\
\text { and capillary-column } \\
\text { GC/MS; graphitized } \\
\text { carbon-based solid-phase } \\
\text { extraction and HPLC/MS }\end{array}$ & $\begin{array}{l}\text { Sandstrom and others, 1994; Lee and others, } \\
\text { 2002; Lee and Strahan, } 2003\end{array}$ & $\begin{array}{l}\text { Filter through baked glass fiber filter, } 0.7-\mu \mathrm{m} \\
\text { nominal pore size, chill sample, and } \\
\text { maintain at } 4^{\circ} \mathrm{C} \text {. }\end{array}$ & $\begin{array}{l}1992,1995 \\
1999-2009\end{array}$ \\
\hline Pesticide screening & USGS NEWSC & $\begin{array}{l}\text { Enzyme-linked } \\
\text { immunosorbent assay }\end{array}$ & Abraxis Corporation, 2010a and 2010b & $\begin{array}{l}\text { Filter through baked glass fiber filter, } 0.7-\mu \mathrm{m} \\
\text { nominal pore size, chill sample, and } \\
\text { maintain at } 4^{\circ} \mathrm{C} \text {. }\end{array}$ & $\begin{array}{l}1992,1995 \\
1999-2009\end{array}$ \\
\hline Major ions & USGS NWQL & Inductively coupled plasma & Fishman and Friedman, 1989; Fishman, 1993 & $\begin{array}{l}\text { Anions: filter through } 0.45-\mu \mathrm{m} \text { filter, Cations: } \\
\text { filter through } 0.45-\mu \mathrm{m} \text { filter, acidify sample } \\
\text { to } \mathrm{pH}<2 \text { with nitric acid }\left(\mathrm{HNO}_{3}\right) \text {. }\end{array}$ & $\begin{array}{c}1992, \\
1999-2009\end{array}$ \\
\hline $\begin{array}{l}\text { Trace elements, including } \\
\text { natural uranium }\end{array}$ & USGS NWQL & $\begin{array}{l}\text { Inductively coupled plasma, } \\
\text { atomic absorption } \\
\text { spectrometry }\end{array}$ & $\begin{array}{l}\text { Fishman and Friedman, 1989; Fishman, 1993; } \\
\text { Garbarino, 1999; Struzeski and others, 1996; } \\
\text { Garbarino and Damrau, 2001; Garbarino and } \\
\text { others, } 2006\end{array}$ & $\begin{array}{l}\text { Filter through } 0.45-\mu \mathrm{m} \text { filter, acidify sample to } \\
\mathrm{pH}<2 \text { with nitric acid }\left(\mathrm{HNO}_{3}\right) \text {. }\end{array}$ & $\begin{array}{c}1992,2008 \text { (for } \\
\text { most constit- } \\
\text { uents) and 1992, } \\
\text { 1999-2009 (iron, } \\
\text { manganse) }\end{array}$ \\
\hline Radon & USGS NWQL & Liquid scintillation & $\begin{array}{l}\text { Whittaker and others, 1989; American } \\
\text { Society for Testing and Materials, } 1998\end{array}$ & $\begin{array}{l}\text { 20-mL glass vial filled with } 10-\mathrm{mL} \text { mineral oil } \\
\text { liquid scintillation cocktail and } 10 \mathrm{~mL} \text { of } \\
\text { sample. Sample must be received at labora- } \\
\text { tory within } 48 \text { hours of collection. }\end{array}$ & 1992,2008 \\
\hline Volatile organic compounds & USGS NWQL & $\begin{array}{l}\text { Purge and trap capillary } \\
\text { column GC/MS }\end{array}$ & Connor and others, 1998 & $\begin{array}{l}\text { Completely fill vial with sample to exclude air } \\
\text { bubbles, acidify sample to a } \mathrm{pH}<2 \text {, protect } \\
\text { sample from sunlight, chill, and maintain } \\
\text { at } 4^{\circ} \mathrm{C} \text {. }\end{array}$ & $2007-2009$ \\
\hline
\end{tabular}


Vienna Standard Mean Ocean Water (VSMOW) standard. The general expression for the $\delta$ value uses the following equation (Kendall and Caldwell, 1998):

$$
\delta_{\text {std }}=\left[\frac{R_{\text {sample }}-R_{\text {standard }}}{R_{\text {standard }}}\right] \times 1000,
$$

where

$$
\begin{gathered}
\delta_{\text {std }} \text { is the } \delta \text { value relative to the standard (AIR or } \\
\text { VSMOW), } \\
R_{\text {sample }} \text { is the ratio of the rare (usually heavy) isotope } \\
\text { to the abundant isotope (for example, } \\
{ }^{15} \mathrm{~N} /{ }^{14} \mathrm{~N} \text { or }{ }^{18} \mathrm{O} /{ }^{16} \mathrm{O} \text { ) in the sample, and } \\
\text { is the ratio of the rare isotope to the abundant } \\
\text { isotope in the standard. }
\end{gathered}
$$

A negative $\delta$ value indicates that the sample is depleted of the rare isotope relative to the standard; that is, the sample is isotopically "light." A positive $\delta$ value indicates that the sample is enriched in the rare isotope relative to the standard; that is, the sample is isotopically "heavy." Additional information on isotopes and their presence in the environment can be found in references such as Kendall and McDonnell (1998) and Clark and Fritz (1997).

\section{Data-Analysis Procedures}

\section{Construction of Water-Table and Potentiometric- Surface Maps}

Contour maps of the water-table altitude were constructed for the Elkhorn, Missouri, and Platte River Valley alluvial aquifers (fig. 2) using water levels typically measured in spring 2009, estimated river altitude, and a published map of the water table in the PMRNRD area for 1995 (University of Nebraska-Lincoln, Conservation and Survey Division, 2010b). If spring 2009 water levels were not available for a well measured by the PMRNRD or USGS, historical water levels for that well were used. The river altitude was estimated using a $10-\mathrm{m}$ digital-elevation model along the river centerline; use of the 10-m digital-elevation model for estimated groundwater altitude (fig. 2) was considered appropriate because of the map scale and because of the relatively shallow river depth (U.S. Geological Survey and Nebraska Department of Natural Resources, 1998). Water-table-altitude contours were not constructed for the upland area alluvial aquifers because few water-level measurements in wells screened in the upland area alluvial aquifers were available, and there was inadequate information about the connection or lack of connection between the saturated parts of the upland area alluvial aquifers.

The Dakota aquifer is semiconfined or unconfined in most of the PMRNRD, except in the areas in Dakota and Thurston Counties where the Dakota aquifer is overlain by Late Cretaceous-age confining units (fig. 3). Because there are few recent measurements of water levels (where the aquifer is unconfined) or hydraulic heads (where the aquifer is confined or semiconfined), a current potentiometric-surface map of the Dakota aquifer in the PMRNRD was not constructed for this report. Instead, a published map of the predevelopment potentiometric surface is shown in figure 3 along with the location of wells with recent (2009) depth-to-water measurements (Helgesen and others, 1993; U.S. Geological Survey, 2010a). These recent (2009) depth-to-water measurements do not indicate any changes to the Dakota aquifer's potentiometric surface since predevelopment.

\section{Depth to Water Estimates}

For this report, depth to water for 2009 was estimated for sampled wells if water levels were not measured by USGS during sample collection or by PMRNRD personnel prior to or after the 2008 irrigation season and if there was information on the depth to top and bottom of the well's screen(s) (appendix 1). The water levels for 2009 were estimated using either (1) the water level reported by the driller at the time the well was constructed on well registration forms (Nebraska Department of Natural Resources, 2010) or (2), if the driller did not report a water level at the time the well was constructed, water level was derived by subtracting the land-surface altitude from the water-level altitude interpolated from figures 2 and 3. Water levels measured by the driller at the time of well construction were the preferred estimate of water level in 2009 because that water level was measured, not estimated, and no large-scale water-level declines currently (2011) have been reported in the PMRNRD area (University of Nebraska-Lincoln, Conservation and Survey Division, 2009).

\section{Conventions for Reporting Analytical Results}

From 1992 to 1998, the NWQL used the Minimum Reporting Limit (MRL) convention for reporting most analytical results. In 1998, the NWQL began implementing a new convention for reporting analytical results, called the longterm method detection limit (LT-MDL) (Childress and others, 1999). With respect to the samples collected for this study, by 2008 NWQL was using (1) the LT-MDL convention for major ions, all nutrients except nitrite, trace elements, and volatile organic compounds, and (2) the MRL convention for nitrite and pesticides. NWQL uses a convention similar to MRL for ${ }^{222}$ radon activity.

Using the MRL-type convention, measured concentrations greater than the MRL generally are reported as an unqualified value. Concentrations less than the MRL are considered "censored" and are reported as "less than" the MRL value.

Using the LT-MDL convention, two concentration levels are used for reporting analytical results- the current method detection level (MDL) and the laboratory reporting level (LRL), which generally is a value equal to two times the MDL. The MDLs and LRLs differ among analytes and analytical methods. MDLs and LRLs are annually reevaluated by 
the NWQL on the basis of laboratory spike-sample measurements and, therefore, can increase or decrease over time. The objective of the LT-MDL convention is to minimize both false positive and false negative errors in the analytical results. The MDL is determined from the standard deviation of long-term laboratory spiked-sample measurements and is set to the level at which false positive errors are minimized to no more than 1-percent probability. The LRL is set to the level at which false negative errors are minimized to no more than 1-percent probability and, as stated previously, is generally equal to twice the MDL.

Under the LT-MDL conventions, concentrations greater than the LRL and the smallest laboratory calibration standard are reported in USGS NWIS (U.S. Geological Survey, 2010a) as the measured value, not qualified with remark codes. A concentration smaller than the MDL is generally termed "censored" and reported in USGS NWIS (U.S. Geological Survey, 2010a) as "less than" the value of the LRL unless informationrich laboratory methods are used for the analysis. In this study, information-rich laboratory methods were used only for analysis of VOCs. Under the LT-MDL conventions, measured concentrations smaller than either the LRL or the smallest laboratory calibration standard but greater than the MDL are reported in USGS NWIS (U.S. Geological Survey, 2010a) as the measured value and qualified by the respective laboratory with a remark code of "E" for estimated. The measured concentration of nutrients, pesticides, and trace elements also will be qualified by the respective laboratory in USGS NWIS (U.S. Geological Survey, 2010a) with an "E" if the analysis did not meet the laboratory's method-specific performance criteria for the method (Childress and others, 1999). For information-rich laboratory methods, the laboratory instruments can provide additional qualitative information about the concentration of the compound and concentrations less than the MDL can be reported in USGS NWIS (U.S. Geological Survey, 2010a) as the measured value, qualified with a remark code of "E" for estimated.

For samples requiring dilution because of interference or low sample volume, which for this study included four analyses for nitrite and three analyses for orthophosphate, the MRL (for nitrite) or LRL and MDL (for orthophosphate) values were multiplied by the dilution factor. For nitrite, concentrations less than the elevated MRL are reported as "less than" the elevated MRL value. For orthophosphate, concentrations of diluted sample analytes less than the elevated MDL are reported as "less than" the elevated LRL value, and concentrations less than the elevated LRL but greater than the elevated MDL are reported as the measured value with an "E" remark code.

Reporting conventions used by USGS laboratories other than NWQL differed but codes used to qualify the analytical results, such as the remark code, have the same meaning and value as those used by NWQL. The OGRL pesticide results are reported in USGS NWIS (U.S. Geological Survey, 2010a) using the MRL reporting convention. The USGS Reston Chlorofluorocarbon Laboratory (RCFC), Reston, Va., results for dissolved gases and CFCs are reported in USGS NWIS
(U.S. Geological Survey, 2010a) (1) without qualification, if the analytical results met RCFC's method reporting criteria and (2) as null with an "U" remark code, if the analyte was analyzed for but not detected. The USGS Reston Stable Isotope Laboratory (RSIL), Reston, Va., reported stable isotope results in USGS NWIS (U.S. Geological Survey, 2010a) without qualification and consistent with precision and accuracy of the standards used in the analysis (Révész and Casciotti, 2007).

TestAmerica Laboratory in Denver, Colo., used a convention for reporting results of analyses for explosives that is similar to the LT-MDL convention. The TestAmerica analytical results in this study were all non-detect; these results were recoded to "less than" the LRL for the respective analyte and loaded into USGS NWIS (U.S. Geological Survey, 2010a).

Other remark codes used in this report to qualify analytical results are $\mathrm{M}$, presence of analyte was verified but could not be quantified; S, most probable value; and V, results likely affected by contamination. The remark code $\mathrm{M}$ was most often used for dissolved oxygen results measured on site; the value was assigned when the dissolved oxygen concentration was less than the concentration that can be reliably detected by the dissolved oxygen meter. The remark code $\mathrm{S}$ was used to qualify specific conductance results that are measured on site; this remark code was used when there were operational problems with the respective meter. The remark code $\mathrm{V}$ was used when the analyte was detected in the QC samples at a similar concentration to the concentration detected in the environmental samples; remark code $\mathrm{V}$ was used to qualify results for two trace elements - copper and mercury.

\section{Data Treatment}

For this report, the analytical results from 1992 to 2009 were "treated" to standardize the quantification of analytical results and qualifiers prior to calculating statistical results and preparing the tables and figures in this report for the study period; however, the analytical results and qualifiers in appendix 2 are not "treated" but are listed as stored in USGS NWIS (U.S. Geological Survey, 2010a). Treatment was necessary, with the statistical analysis procedures used in this study, prior to analysis because the results for most analytes from 1992 to 2009 incorporated different reporting conventions (MRL, LTMDL, or other) and different MRL or MDL and LRL values. Without treatment, many of these results, as stored in USGS NWIS (U.S. Geological Survey, 2010a), are not statistically comparable using the selected statistical methods (Helsel, 2005a). The treatment approach was to redefine the stored value and the associated remark code for the 1992 to 2009 and 2007 to 2009 periods in USGS NWIS (U.S. Geological Survey, 2010a) by first determining maximum MRL or LRL in each time period. This determination disregarded the analytical method and did not include elevated MRLs or LRLs resulting from dilutions of the original sample. The treated results for the 1992 to 2009 and 2007 to 2009 periods for a given analyte were derived as follows: 
- If the original analytical result was qualified with a "less than" remark code, the treated analytical result was encoded as less than the corresponding maximum MRL or LRL;

- If either (1) the original analytical result was not qualified and was less than the maximum MRL or LRL or (2) the original analytical result was qualified with a remark code of $\mathrm{E}$ or $\mathrm{V}$ and was less than or equal to the maximum MRL or LRL, the treated analytical result was encoded as less than the corresponding maximum MRL or LRL;

- If the original result has censored quantification (for example, the remark code was $\mathrm{M}$ ), the treated analytical result was encoded as less than the corresponding maximum MRL or LRL or the minimum unqualified concentrations for this analyte;

- If the original result was determined after diluting the sample and was qualified as "less than" an elevated MRL or LRL, the treated analytical result was encoded as less than the corresponding maximum MRL or LRL for undiluted results; and

- If either (1) the original remark code was blank and the original result was greater than or equal to the maximum MRL or LRL or (2) the remark code was E or V and the original result was greater than the maximum LRL, the treated analytical result was encoded as the original result with no qualification.

The authors assumed that no errors were introduced in applying the treatment described above.

\section{Statistical Methods}

Statistical measures calculated for this report include summary statistics (median and percentile concentrations or values) and correlation analysis using the following methods.

- The regression-on-order statistics method (Helsel and Cohn, 1988; David Lorenz, U.S. Geological Survey, written commun., March 2010) was used to calculate summary statistics for sets of treated analytical results with censored values. For example, the regressionon-order statistics method was used to determine the median concentration of nitrate-N during 1992-2009.

- The generalized Wilcoxon test (David Lorenz, U.S. Geological Survey, written commun., March 2010) was performed on flipped data (Helsel, 2005b, p. 17, 145-150) to compare groups of treated analytical results with censored values to each other. For example, the generalized Wilcoxon test was used to compare iron results from the Dakota aquifer samples to iron results from the Elkhorn River Valley alluvial aquifer samples.
- The Kendall tau test with the Akritas-Theil-Sen slope estimate (Akritas and others, 1995; David Lorenz, U.S. Geological Survey, written commun., March 2010) was used to test correlations for sets with censored values (Helsel, 2005b, p. 189-192 and 212215). For example, the Kendall tau test was used to determine whether there was a significant trend in summer-to-fall nitrate-N concentrations for each year from 1999 to 2009 in a given well in the well nests. The value of tau will be approximately zero if the correlates are independent. Tau will be greater than zero for a positive correlation and tau will be less than zero for a negative correlation.

- Nonparametric methods were used to calculate summary statistics for data sets without censored values and to test whether there was a significant relation between groups of analytical results. The tests used to determine a relation between groups of results were (1) Spearman's correlation to compare two paired groups or (2) the Kruskal-Wallis rank-sum test of differences to compare more than two groups (Helsel and Hirsch, 1992).

In this report, statistical-test results were evaluated using a significance level of 95 percent $(\alpha=0.05)$. A significance level is the probability that the test conclusion is accurate for the populations under consideration. The $p$-value associated with a particular test-statistic result is the probability of obtaining a test statistic equal to or more unlikely than the computed value from repeated sampling when the null hypothesis is true. A typical null hypothesis is that the difference in the medians of the two populations is zero. A $p$-value of 0.05 or less was used in this report to assert, with 95 percent confidence, that there is a statistically significant difference between populations or that two groups are significantly correlated.

\section{Water-Quality Standards}

Analyte concentrations in groundwater may be of concern when they approach levels that may be harmful to human health. Several types of standards were used to identify analyte concentrations of potential concern. In this report, the analyte results for groundwater in the PMRNRD are grouped into the following categories: groundwater-age dating, dissolved gases, explosives, major ions, nutrients, pesticides, ${ }^{222}$ radon, stable isotopes, trace elements, and VOCs. The analytes included in each category are listed in appendixes 3 through 7, along with the standard(s) currently (2011) associated with each analyte. The number of samples per well is listed in appendix 8.

The following types of groundwater-quality standards are compared to PMRNRD water-quality results in this report: 


\begin{tabular}{|c|c|c|}
\hline Abbreviation & Description & Comments \\
\hline $\mathrm{MCL}$ & Maximum Contaminant Level & $\begin{array}{l}\text { U.S. Environmental Protection Agency (USEPA) determines MCLs for selected analytes. } \\
\text { MCLs are legally enforceable standards for the maximum permissible level of an ana- } \\
\text { lyte in drinking water that is delivered by a public water system (U.S. Environmental } \\
\text { Protection Agency, 2009a). }\end{array}$ \\
\hline
\end{tabular}

Title $118 \quad$ Nebraska Title-118 standard

Nebraska Department of Environmental Quality sets standards for selected analytes. Nebraska Title-118 standards, which generally are the same as the USEPA MCLs, are the groundwater-quality standards used by the Nebraska Department of Environmental Quality, when applicable, in administration of regulatory programs related to groundwater other than groundwater delivered by public water systems as drinking water (Nebraska Department of Environmental Quality, 2006).

$\begin{array}{ll}\text { AMCL } & \text { Alternative MCL } \\ & \\ \text { SDWR } & \begin{array}{l}\text { Secondary Drinking Water } \\ \text { Regulation }\end{array}\end{array}$

Drinking Water Advisory Table

$\begin{array}{cc}\text { TT Action } & \text { Treatment Technique Action } \\ \text { Level } & \text { Level }\end{array}$

LTHA Lifetime Health Advisory level

$10^{-4} \mathrm{CR} \quad 10^{-4}$ Cancer Risk

DWEL Drinking Water Equivalent Level
AMCLs are legally enforceable standards set by USEPA for the maximum permissible level of analytes in drinking water that is delivered by a public water system; the AMCL is applicable only in specific circumstances. The only AMCL relevant to this report is the proposed AMCL for ${ }^{222}$ radon, which is 4,000 picocuries per liter ( $\mathrm{pCi} / \mathrm{L}$ ) for public water supplies that have a program to limit radon exposure (U.S. Environmental Protection Agency, 2009a and 2010b).

SDWRs are nonenforceable Federal guidelines for drinking water set by the USEPA and relate to the maximum concentration of an analyte to avoid adverse cosmetic or aesthetic effects. Possible cosmetic effects are tooth or skin discoloration; possible aesthetic effects are water with undesirable taste, odor, or color (U.S. Environmental Protection Agency, 2009a).

DWATs are nonregulatory upper concentration limits for analytes in drinking water. These limits are set by the USEPA at a level that is unlikely to cause adverse effects on health or aesthetic properties. A DWAT-Low sodium diet suggests maximum concentrations for individuals on a restricted sodium diet (U.S. Environmental Protection Agency, 2009a).

TT Action Levels are legally enforceable standards for copper and lead concentration in drinking water delivered to the consumer and are applicable to public water systems only. If more than 10 percent of the sampled tap water exceeds the TT Action Level, the public water system must take corrective steps (U.S. Environmental Protection Agency, 2009b).

Nonenforceable USEPA guideline for the maximum concentration of a constituent in drinking water that is not expected to cause any adverse noncarcinogenic effects after a lifetime of exposure. LTHAs are calculated assuming consumption of 2 liters of water per day over a 70-year lifetime by a 154-pound (70-kilogram) adult and that 20 percent of a person's exposure to this constituent comes from drinking water (U.S. Environmental Protection Agency, 2009a).

Nonenforceable USEPA guideline for the concentration of a constituent in drinking water that corresponds to an excess estimated lifetime-cancer risk of 1 in 10,000 (U.S. Environmental Protection Agency, 2009a).

Nonenforceable USEPA guideline for lifetime-exposure concentration that will not result in adverse, non-cancer health effects. DWEL assumes all exposure to the constituent is from drinking water (U.S. Environmental Protection Agency, 2009a). 


\section{Age Dating of Groundwater Using Chlorofluorocarbons}

CFCs were used to estimate the apparent recharge age of groundwater in the PMRNRD. The apparent recharge age, called groundwater age in this report, refers to the time elapsed since recharge and isolation of the newly recharged water from the soil atmosphere. CFC age-dating techniques estimate groundwater age on the basis of increasing concentrations of three CFC gases [dichlorodifluoromethane (CFC-12), trichlorofluoromethane (CFC-11), and trichlorotrifluoroethane (CFC-113)] introduced into the North American air from the 1930s to the 1990s. During that period, CFCs were used as refrigerants, aerosol propellants, cleaning agents, solvents, and blowing agents in the production of foam, rubber, and plastics. CFCs used in these processes eventually leaked into the atmosphere at a nearly linear rate (fig. 9) and subsequently were transported into the hydrosphere where they could be used as environmental tracers in age-dating groundwater (Plummer and Busenberg, 2000). The concentrations of these three compounds in groundwater samples provide three independent estimates of apparent recharge or modeled groundwater age. Results of the CFC analyses were examined using two flow or mixing scenarios-piston flow (water moving as a slug) and binary mixing (old water mixed with young water). Additional information on the use of CFCs to date groundwater can be found in text books such as Clark and Fritz (1997).

Dissolution of gases (nitrogen, argon, methane, carbon dioxide, and oxygen) produces measureable gas concentrations in groundwater, which, in turn, allows for calculation of estimated excess air concentrations, recharge temperature, and recharge elevation. In addition, concentrations of dissolved oxygen, excess dissolved nitrogen, or dissolved methane can be indicators of reducing and denitrifying conditions in the

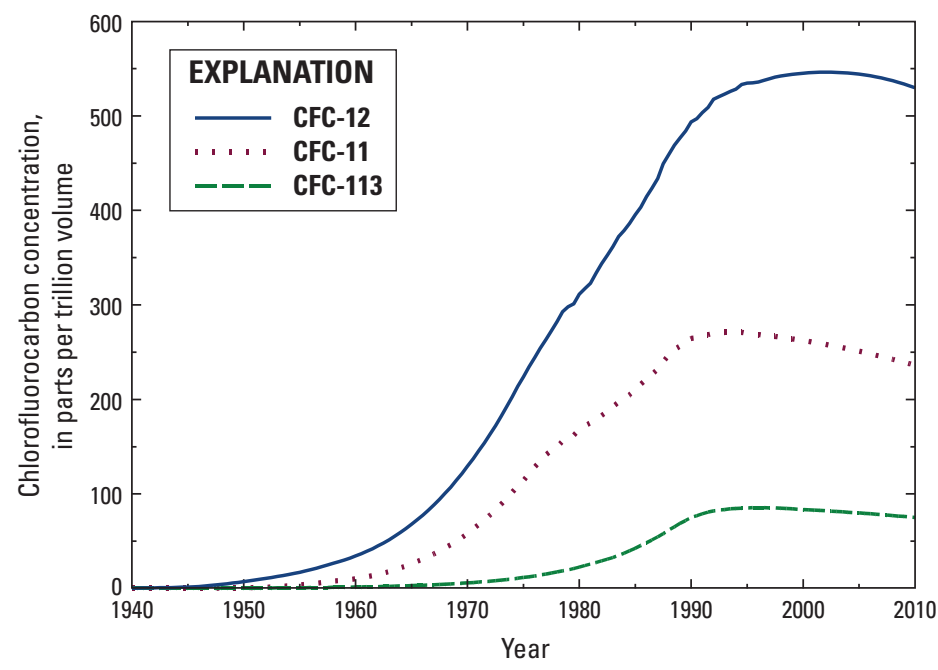

Figure 9. Atmospheric concentrations of chlorofluorocarbons (CFCs) in North American air, 1940-2010. (Modified from U.S. Geological Survey, 2011). aquifer. Analyses of samples for dissolved gases were completed at the RCFC Laboratory (Peggy Widman, U.S. Geological Survey, written commun., 2001). Dissolved gases were used to help determine groundwater age from CFC concentrations by constraining the conditions of water temperature and elevation at the time of recharge.

\section{Reduction-0xidation Reactions}

To analyze the types of reduction-oxidation (redox) reactions occurring in groundwater in the PMRNRD over time, the samples collected from 1999 to 2009 in each of the wells in well nests that had results for dissolved oxygen, nitrate, manganese, iron, and sulfate were selected. For each well in the well nests, there were 4 to 12 samples for each water year from 1999 to 2009 that satisfied these criteria. The concentrations of these constituents from each sample were input to a worksheet used to predict the prevalent redox processes for each sample as described by Jurgens and others (2009).

\section{Denitrification}

Estimated excess nitrogen, which is calculated from estimated recharge temperature and concentrations of dissolved gases, can be used to estimate the initial nitrate value, prior to denitrification, using the following equation (McMahon and others, 2007):

$$
\left[\mathrm{NO}_{3}^{-}\right]_{\text {initial }}=\left[\mathrm{NO}_{3}^{-}\right]_{\text {measured }}+2 \times\left[\text { excess } \mathrm{N}_{2}\right],
$$

where

$$
\begin{gathered}
{\left[\mathrm{NO}_{3}^{-}\right] \text {and }\left[\text { excess } \mathrm{N}_{2}\right] \text { are expressed in micromoles }} \\
\operatorname{per} \operatorname{liter}\left(\frac{\mu \mathrm{M}}{\mathrm{L}}\right) .
\end{gathered}
$$

The process of denitrification was quantified by calculating the fraction $(f)$ of the initial $\mathrm{NO}_{3}{ }^{-}$in recharge that has been removed by denitrification using the following equation (McMahon and others, 2007):

$$
f=1-\frac{\left[\mathrm{NO}_{3}^{-}\right]_{\text {measured }}}{\left[\mathrm{NO}_{3}^{-}\right]_{\text {initial }}} .
$$

\section{Quality Assurance and Quality Control}

QC samples collected for the PMRNRD study include source-solution blanks, field blanks, equipment blanks, field replicates, laboratory matrix spikes, and reference samples. QC samples were collected to evaluate evidence of contamination of the samples and bias and variability of the waterchemistry data that may have originated during collecting, processing, storing, or analyzing the samples. 


\section{Field-Blank, Equipment-Blank, and Source- Solution Blank Samples}

Field-blank samples were collected to determine the occurrence and magnitude of sample contamination during sample collection, processing, and analysis. Blank samples were collected using water that was specially prepared and certified to be free of relevant categories of constituents (for example, inorganic-free or organic-free blank water). Blank samples were analyzed for nutrients, pesticides, major ions, trace elements, VOCs, and explosives. Because it is not presently (2012) possible to prepare blank water that is certifiably free of CFCs, dissolved gases, nitrogen isotopes, or radon, no field- or equipment-blanks samples were collected for analysis for these constituents.

Field-blank sample results for constituents with detections are summarized in table 5. Median concentrations in blank samples indicated that sample contamination generally was minimal for all constituents. Maximum concentrations in blank samples for some major ions-silica, sodium, and sulfate - and some trace elements - cadmium, iron, lead, manganese, mercury, and silver - were within an order of magnitude or exceeded the lowest environmental-sample concentrations. These results indicate concentrations in environmental samples collected in the same time period as these blanks should be used with caution. Maximum concentrations in blank samples for some trace elements - cadmium, lead, and silver - were within an order of magnitude or exceeded the highest environmental-sample concentrations. Results for these blanks were further investigated using equipment-blank samples to determine the likely source of contamination in the sample-collection or -processing procedures. This investigation indicated that, in 2008, a possible source of the contamination was the sample tubing used to deliver water from the pump to the sample preservation chamber.

\section{Replicate Samples}

Replicate samples are two (or more) environmental samples collected sequentially for duplicate analysis of approximately the same sample water. Replicate samples were collected to determine the variability of the data resulting from sampling and analytical procedures. The relative percent difference (RPD) between concentrations of paired replicate samples was calculated (table 6) using the formula

$$
R P D=\frac{\mid \text { sample } 1-\text { sample } 2 \mid}{\left(\frac{\text { sample } 1+\text { sample } 2}{2}\right)} \times 100
$$

When there is no variability between the paired analyses, the RPD is zero percent. The RPD was not calculated if one or both of the paired replicate concentrations were less than the maximum LRL or quantified as an estimated value by the laboratory.
There were 48 individual constituents with paired environmental and replicate samples (table 6 ). The median RPD by constituent group for environmental samples ranged from 0 to 16 percent. The constituent groups that had the largest median RPDs were stable isotopes (16 percent) and pesticides ( 8 percent). Stable isotope replicates were collected only in 2004. A possible reason for the large variation in the stable isotopes replicability in 2004 could be inadequate pumping of the wells in well nests prior to sampling (J.K. Böhlke, U.S. Geological Survey, written commun., 2005). Pesticide analysis generally resulted in very small [less than 1 microgram per liter $(\mu \mathrm{g} / \mathrm{L})]$ concentrations. For very small concentrations, small differences in replicates can cause large calculated variability. For the constituent groups other than stable isotopes and pesticides, the individual analytes with the largest average RPDs were silver (40 percent), nitrite (38 percent), methane (27 percent), dissolved oxygen (16 percent), and orthophosphate (12 percent). The average RPDs for individual analytes indicated an acceptable amount of variability between paired environmental and replicate samples.

\section{Laboratory Matrix Spikes}

Laboratory matrix-spike (LMS) results are used to quantify the imprecision or bias (apparent gain or loss of analytes) resulting from groundwater properties (that is, matrix effects) or laboratory procedures. LMSs are not intended to quantify the apparent gain or loss of analytes during sample holding time or from field procedures. A spike recovery of about 100 percent indicates minimal matrix interference or errors in laboratory procedures. A spike recovery of less than or greater than 100 percent indicates matrix interference or errors in laboratory procedures. In this study, LMS samples were used for QC of analyses of explosive and pesticide compounds. When a second LMS sample was collected, it was referred to as a laboratory matrix-spike duplicate (LMSD).

The LMS and LMSD samples were shipped to the laboratory concurrently with the environmental samples. Prior to analysis, the laboratory added a specified amount of the target analytes to the designated LMS and LMSD sample bottles and generally analyzed these QC sample(s) and the associated environmental samples in the same "batch" (run cycle of the analytical instrument). In 2008, samples for LMS and LMSD were submitted for one site (E-V1) for explosive analysis, and samples for LMS were submitted for one site (E-V3) for pesticide analysis. In 2009, samples for LMS and LMSD were submitted for one site (P-A3) for pesticide analysis. The RPDs and percent recoveries for these laboratory matrix spikes are summarized in table 6 .

In 2008, percent recovery for explosives in the LMS ranged from 56 to 160 percent; the RPD between results in the LMS and LMSD samples were 0 to 30 percent (table 6). The results for 1,3,5-trinitrohexahydro-1,3,5-triazine, also called royal demolition explosive (RDX), which is the explosive analyte that is most widespread at the former Nebraska Ordnance Plant (NOP) about 6 mi west of Gretna, Nebr. (U.S. Army 
Table 5. Constitutents detected in field-blank samples, Papio-Missouri River Natural Resources District, eastern Nebraska, $1992-2009$.

[LRL, laboratory reporting level; MDL, method detection level; $\mu \mathrm{g} / \mathrm{L}$, micrograms per liter; --, no data or not calculated; E, estimated; mg/L, milligrams per liter; Nitrate-N, nitrate plus nitrite as nitrogen; $<$, less than]

\begin{tabular}{|c|c|c|c|c|c|c|c|c|c|c|}
\hline Constitutent & $\begin{array}{l}\text { Parameter } \\
\text { code }\end{array}$ & $\begin{array}{l}\text { Number of } \\
\text { field-blank } \\
\text { samples }\end{array}$ & $\begin{array}{l}\text { Maximum } \\
\text { LRL, } \\
\text { 1992-2009 }\end{array}$ & $\begin{array}{c}\text { Number of } \\
\text { detections } \\
\text { above the } \\
\text { maximum } \\
\text { LRL, } \\
\text { 1992-2009 }\end{array}$ & $\begin{array}{c}\text { Number of } \\
\text { detections at or } \\
\text { above the LRL or } \\
\text { MDL at the time } \\
\text { the sample was } \\
\text { analyzed }\end{array}$ & $\begin{array}{c}\text { Median } \\
\text { concentration' } \\
\text { of detected } \\
\text { analytes in field- } \\
\text { blank samples }\end{array}$ & $\begin{array}{c}\text { Maximum } \\
\text { concentration }{ }^{1} \\
\text { in field-blank } \\
\text { samples }\end{array}$ & $\begin{array}{l}\text { Range of dates for } \\
\text { blank samples }\end{array}$ & $\begin{array}{c}\text { Range of concentrations } \\
\text { in environmental } \\
\text { samples }{ }^{1}\end{array}$ & $\begin{array}{c}\text { Range of dates for } \\
\text { environmental samples }\end{array}$ \\
\hline \multicolumn{11}{|c|}{ Pesticide compounds (concentrations in $\mu \mathrm{g} / \mathrm{L}$ ) } \\
\hline Atrazine & 39632 & 11 & 0.05 & 1 & 1 & -- & 0.05 & $\begin{array}{l}1992,1995, \\
2001-2009\end{array}$ & E0.01-1.8 & $\begin{array}{l}\text { 1992, 1995, } \\
1999-2009\end{array}$ \\
\hline \multicolumn{11}{|c|}{ Nutrients (concentrations in $\mathrm{mg} / \mathrm{L}$ ) } \\
\hline Ammonia & 00608 & 60 & 0.04 & 0 & 5 & E0.007 & E0.012 & $1995,1999-2009$ & E0.005-1.81 & $\begin{array}{c}1995, \\
1999-2009\end{array}$ \\
\hline Nitrate-N & 00631 & 150 & .06 & 0 & 3 & E.03 & E.04 & $\begin{array}{c}1992-1995 \\
1998-2009\end{array}$ & E0.02-74.6 & $1992-2009$ \\
\hline Ortho-phosphate & 00671 & 60 & .02 & 0 & 3 & E.005 & E.005 & $1995,1999-2009$ & $0.007-1.0$ & $\begin{array}{c}1995, \\
1999-2009\end{array}$ \\
\hline \multicolumn{11}{|c|}{ Major ions (concentrations in $\mathrm{mg} / \mathrm{L}$ ) } \\
\hline Calcium & 00915 & 35 & 0.04 & 5 & 19 & E0.02 & 0 & 1992, 1999-2009 & $42.3-210$ & $\begin{array}{c}1992 \\
1999-2009\end{array}$ \\
\hline Magnesium & 00925 & 35 & .02 & 2 & 5 & E. 008 & 0 & 1992, 1999-2009 & $6.34-57.3$ & $\begin{array}{c}1992, \\
1999-2009\end{array}$ \\
\hline Potassium & 00935 & 25 & .16 & 0 & 1 & -- & E0.01 & 1992, 1999-2009 & $1.8-28.5$ & $\begin{array}{c}1992 \\
1999-2009\end{array}$ \\
\hline Silica & 00955 & 35 & .5 & 1 & 1 & -- & 0 & 1992, 1999-2009 & $9.1-38$ & $\begin{array}{c}1992 \\
1999-2009\end{array}$ \\
\hline Sodium & 00930 & 35 & .2 & 1 & 3 & E.09 & 0 & $1992,1999-2009$ & $7.6-140$ & $\begin{array}{c}1992, \\
1999-2009\end{array}$ \\
\hline Sulfate & 00945 & 35 & .31 & 0 & 2 & -- & 0 & 1992, 1999-2009 & $0.8-590$ & $\begin{array}{c}1992, \\
1999-2009\end{array}$ \\
\hline \multicolumn{11}{|c|}{ Trace elements (concentrations in $\mu \mathrm{g} / \mathrm{L}$ ) } \\
\hline Boron & 01020 & 4 & 10 & 0 & 3 & 1.2 & 1.2 & 1992,2008 & $30-730$ & 1992,2008 \\
\hline Cadmiun & 01025 & 4 & 1 & 1 & 1 & -- & 0 & 1992, 2008 & E0.02-3 & 1992,2008 \\
\hline Iron & 01046 & 35 & 10 & 1 & 1 & -- & 0 & $1992,1999-2009$ & E2-17,000 & $\begin{array}{c}1992 \\
1999-2009\end{array}$ \\
\hline Lead & 01049 & 4 & 10 & 0 & 1 & -- & 5.47 & 1992, 2008 & E0.04-1.16 & 1992,2008 \\
\hline Manganese & 01056 & 35 & 3.2 & 1 & 8 & 1.1 & 0 & $1992,1999-2009$ & $<0.2-2,300$ & $\begin{array}{c}1992 \\
1999-2009\end{array}$ \\
\hline Mercury & 71890 & 3 & .01 & 2 & 2 & .014 & .03 & 2008 & E0.007-0.077 & 2008 \\
\hline Silver & 01075 & 4 & 1 & 1 & 1 & -- & 0 & 1992,2008 & $<0.1-3$ & 1992,2008 \\
\hline Strontium & 01080 & 4 & .8 & 1 & 1 & -- & 0 & 1992,2008 & $220-4,500$ & 1992,2008 \\
\hline
\end{tabular}

${ }^{1}$ Summarized concentrations were those at or above the laboratory reporting or method detection level at the time the sample was analyzed. 
Table 6. Summary of relative percent differences for replicate samples and percent recoveries for laboratory matrix-spike and reference samples, Papio-Missouri River Natural Resources District, eastern Nebraska, 1992-2009.

[RPD, relative percent difference; --, not calculated; LMS, laboratory matrix spike; LMSD, laboratory matrix-spike duplicate]

\begin{tabular}{|c|c|c|c|c|c|c|c|c|c|c|}
\hline \multirow{2}{*}{$\begin{array}{c}\text { Compound class } \\
\text { (number of analytes with } \\
\text { data') }\end{array}$} & \multirow{2}{*}{$\begin{array}{l}\text { Range of dates, by } \\
\text { water year', with } \\
\text { replicate samples }\end{array}$} & \multirow{2}{*}{$\begin{array}{l}\text { Number of } \\
\text { replicated or } \\
\text { spiked values }^{1}\end{array}$} & \multirow[b]{2}{*}{ Minimum } & \multicolumn{6}{|c|}{ Value of indicated percentile ${ }^{1}$} & \multirow[b]{2}{*}{ Maximum } \\
\hline & & & & 10 & 25 & 50 & 75 & 90 & 95 & \\
\hline \multicolumn{11}{|c|}{ Comparison of environmental and replicate sample results (RPD, in percent) } \\
\hline Dissolved gases (5 analytes) & 2000,2004 & 67 & 0 & 0 & 0 & 1 & 2 & 24 & 62 & 130 \\
\hline Explosives ( 0 analytes $)$ & 2008-2009 & -- & -- & -- & -- & -- & -- & -- & -- & -- \\
\hline Major ions (10 analytes) & $1992,1999-2009$ & 346 & 0 & 0 & 0 & 1 & 3 & 6 & 9 & 120 \\
\hline Nutrients (4 analytes) & $\begin{array}{l}\text { 1992-1994, } \\
1997-2009\end{array}$ & 151 & 0 & 0 & 0 & 1 & 5 & 22 & 40 & 130 \\
\hline Pesticides (14 analytes) & 2002-2009 & 25 & 0 & 0 & 1 & 8 & 22 & 57 & 67 & 71 \\
\hline${ }^{222}$ Radon (1 analyte) & 2008 & 4 & 0 & 0 & 0 & 0 & 6 & 11 & 11 & 11 \\
\hline Stable isotopes (3 analytes) & 2004 & 6 & 4 & 4 & 8 & 16 & 30 & 47 & 47 & 47 \\
\hline Trace elements (11 analytes) & $1992,1999-2009$ & 91 & 0 & 0 & 0 & 1 & 4 & 7 & 10 & 56 \\
\hline $\begin{array}{l}\text { Volatile organic compounds } \\
\text { (VOCs) (0 analytes })\end{array}$ & 2008-2009 & -- & -- & -- & -- & -- & -- & -- & -- & -- \\
\hline \multicolumn{11}{|c|}{ Comparison of LMS and LMSD sample results (RPD, in percent) } \\
\hline $\begin{array}{l}\text { Pesticides and pesticide } \\
\text { degradates ( } 22 \text { analytes) }\end{array}$ & 2008-2009 & 22 & 4 & 7 & 30 & 48 & 61 & 71 & 80 & 89 \\
\hline Explosives (16 analytes) & 2008 & 16 & 0 & 7 & 21 & 23 & 25 & 29 & 30 & 30 \\
\hline \multicolumn{11}{|c|}{ Recovery of measured spike amount in LMS samples (in percent) } \\
\hline $\begin{array}{l}\text { Pesticides and pesticide } \\
\text { degradates ( } 54 \text { analytes) }\end{array}$ & $2008-2009$ & 53 & 39 & 64 & 83 & 92 & 110 & 120 & 140 & 220 \\
\hline Explosives (16 analytes) & 2008 & 16 & 56 & 76 & 100 & 120 & 120 & 140 & 160 & 160 \\
\hline \multicolumn{11}{|c|}{ Comparison of reference-sample results from method 8330 and method 8321a analysis (RPD, in percent) } \\
\hline Explosives (13 analytes) & 2008 & 13 & 6 & 6 & 12 & 18 & 25 & 32 & 39 & 39 \\
\hline \multicolumn{11}{|c|}{ Recovery of measured reference amount from method 8330 and method 8321 a analysis (in percent) } \\
\hline $\begin{array}{l}\text { Explosives, method } 8330 \\
\text { (13 analytes) }\end{array}$ & 2008 & 13 & 86 & 89 & 100 & 110 & 120 & 130 & 150 & 150 \\
\hline $\begin{array}{l}\text { Explosives, method 8321a } \\
\text { (13 analytes) }\end{array}$ & 2008 & 13 & 72 & 78 & 94 & 97 & 100 & 110 & 110 & 110 \\
\hline
\end{tabular}

${ }^{1}$ Percent difference was not calculated, and the replicate was not included in the table if the laboratory results of either the environmental or replicate sample were qualified with remark code "E" or " $<$."

${ }^{2}$ Water year is the 12-month period beginning October 1 and ending September 30. It is designated by the year in which it ends.

Corp of Engineers, 2008), were percent recoveries of 113 and 89 for the LMS and LMSD, respectively, and RPD of 24. These LMS and LMSD results for RDX were considered acceptable, and qualifying comments were not recommended for RDX (Carl Schlosslin, Analytical Quality Associates, Inc., Albuquerque, N. Mex., written commun., 2008). The LMS and LMSD results for explosives were used to annotate the analytical results with comments to indicate the precision and accuracy of the results, but they were not used to disqualify or modify analytical results included in this study because all environmental results for the explosive compounds were nondetects and, therefore, were not subject to statistical analysis.

In 2008 and 2009, the percent recoveries for the pesticide analytes in the LMS samples ranged from 39 to 220 percent.
In 2009, the RPD for the pesticide analytes in the LMS and LMSD samples ranged from 4 to 89 percent (table 6). The LMS and LMSD results for pesticides were used to indicate the precision and accuracy of the results, but they were not used to disqualify or modify analytical results included in this study.

\section{Reference Samples}

A reference sample and associated replicate were used in 2008 to indicate the precision and accuracy of laboratory analytical procedures for analysis of explosive analytes. The concentration of each analyte in the reference sample and 
associated replicate was certified by the supplier to range from $0.30 \mu \mathrm{g} / \mathrm{L}$ for RDX to $1.87 \mu \mathrm{g} / \mathrm{L}$ for 2-nitrotoluene (Heidi M. Senft, Environmental Resource Associates, Denver, Colo., written commun., 2008). The reference sample and associated replicate were submitted with the environmental samples for one site in 2008. The reference sample was analyzed using USEPA method 8330, the standard USEPA method for explosives, and the replicate sample was analyzed using USEPA method 8321a. All environmental samples were analyzed using USEPA method 8330, and one environmental sample was also analyzed using method $8321 \mathrm{a}$. A reference sample recovery result of about 100 percent indicates that (1) there was minimal compound degradation from the time the sample was certified until the sample was analyzed and (2) the laboratory's analysis procedures were accurate and precise.

The replication differences in the results for the reference sample and associated replicate, and the percent recoveries for the reference sample and associated replicate, are summarized in table 6 . The median percent recovery values for all explosive compounds in the reference sample were 110 percent (method 8330) and 97 percent (method 8321a). The percent recovery of each explosive compound ranged from 86 to 150 percent with method 8330 , and 72 to 110 percent with method 8321a. The maximum RPD between the two methods was 39 percent (table 6) for analysis of RDX. The analytical results for RDX were $0.46 \mu \mathrm{g} / \mathrm{L}$ using method 8330 and $0.31 \mu \mathrm{g} / \mathrm{L}$ using method 8321a.

\section{Groundwater Altitude}

A map of the water-table-altitude contours was created for the Elkhorn, Missouri, and Platte River Valley alluvial aquifers using water levels measured in spring 2009, estimated river altitude, and a published map of the water table in the PMRNRD area for 1995 (fig. 2). Because of insufficient data, water-table-altitude contours were not created for the upland area alluvial aquifers, and a current potentiometric-surface map was not created for the Dakota aquifer (fig. 3). In the PMRNRD, groundwater altitude, relative to the NGVD 29 datum, ranged from about 1,080 $\mathrm{ft}$ to $1,180 \mathrm{ft}$ in the Elkhorn River Valley alluvial aquifer and from about $960 \mathrm{ft}$ to $1,080 \mathrm{ft}$ in the Missouri River Valley and Platte River Valley alluvial aquifers. Groundwater flow generally is toward or parallel to the rivers. In the PMRNRD, the estimated altitude of the potentiometric surface of the Dakota aquifer, predevelopment, ranged from about $1,100 \mathrm{ft}$ to $1,200 \mathrm{ft}$. Groundwater flow in the Dakota aquifer is generally toward the east.

Groundwater velocity can be estimated using groundwater gradient, horizontal hydraulic conductivity, and effective porosity (Freeze and Cherry, 1979). Groundwater gradient was estimated for each aquifer using figures 2 and 3, except because of lack of data, the upland area alluvial aquifers.

Groundwater gradients were about 5.0 feet per mile $(\mathrm{ft} / \mathrm{mi})$ for the Dakota aquifer, $5.3 \mathrm{ft} / \mathrm{mi}$ for the Elkhorn River Valley alluvial aquifer, $3.1 \mathrm{ft} / \mathrm{mi}$ for the Missouri River Valley alluvial aquifer, and $5.7 \mathrm{ft} / \mathrm{mi}$ for the Platte River Valley alluvial aquifer. Horizontal hydraulic conductivity and effective porosity were estimated to be 25 feet per day (ft/d) and 0.15 (dimensionless), respectively, for the Dakota aquifer (Helgesen and others, 1993); $150 \mathrm{ft} / \mathrm{d}$ and 0.15 (dimensionless), respectively, for the Elkhorn River Valley alluvial aquifer (Gutentag and others, 1984); and $700 \mathrm{ft} / \mathrm{d}$ and 0.17 (dimensionless), respectively, for a section of the Missouri River Valley alluvial aquifer downgradient from the PMRNRD (Emmett and Jeffery, 1969; Smith and Richards, 2008). Because the lithologic descriptions of the Missouri and Platte River Valleys alluvial aquifers in the PMRNRD are similar to that of the Elkhorn River Valley alluvial aquifer (table 1), for the purpose of this study, horizontal hydraulic conductivity and effective porosity for the Missouri and Platte River Valleys alluvial aquifers were assumed to be the same as those for the Elkhorn River Valley alluvial aquifer. Groundwater velocity was estimated as $0.2 \mathrm{ft} / \mathrm{d}$ for the Dakota aquifer, $1.0 \mathrm{ft} / \mathrm{d}$ for the Elkhorn and Platte River Valleys alluvial aquifers, and $0.6 \mathrm{ft} / \mathrm{d}$ for the Missouri River Valley alluvial aquifer.

\section{Groundwater Age}

Samples analyzed for both CFCs and dissolved gases (appendix 7) were collected from 15 wells in well nests in June 2000 (appendix 8). Results for dissolved gases, including dissolved oxygen concentrations less than 0.5 milligrams per liter $(\mathrm{mg} / \mathrm{L})$; the presence of methane; or the presence of excess nitrogen gas indicate that anoxic or reducing conditions were present in all samples, except the sample from well P-S1 (table 7). Reducing conditions could result in the degradation of CFC-11 and CFC-113, but reducing conditions typically do not greatly affect the concentration of CFC-12 (Plummer and Busenberg, 2000); therefore, where appropriate, CFC-12 concentrations are given more weight in the age-dating analysis.

Groundwater ages (as of 2000) ranged from early 1960s to early 1980s in 3 samples from the Dakota aquifer, early 1960s to 1970s in 3 samples from the Elkhorn River Valley alluvial aquifer, older than 1940 and late 1960s to early 1970s in 3 samples from the Missouri River Valley alluvial aquifer, mid-to-late 1950s and early-to-mid 1970s in 5 samples from the Platte River Valley alluvial aquifer, and early 1970s in 1 sample from one of the upland area alluvial aquifers (table 7). As expected, groundwater age in the shallow well of a given well nest was approximately the same or younger than water from the deepest well from the same well nest. These results for the Elkhorn and Platte River Valleys alluvial aquifers are consistent with age-dating result from tritium analysis of samples collected from 2002 to 2004 in the eastern part of what is termed the Platte River Valley hydrogeologic unit of the High Plains aquifer (Stanton and Qi, 2007). If all of these wells were resampled for CFCs currently (2011), the 
Table 7. Analytical results for dissolved gases and chlorofluorocarbons in samples collected in 2000 and calculated results associated with determining the apparent age of groundwater using chlorofluorocarbons, Papio-Missouri River Natural Resources District, eastern Nebraska.

[All dates calculated from month and year of sample collection. $\mathrm{mg} / \mathrm{L}$, milligram per liter; ${ }^{\circ} \mathrm{C}$, degrees Celcius; $\mathrm{N}_{2}$, nitrogen gas; $\mathrm{CFC}$, chlorofluorocarbon; pptv, part per trillion by volume; $\mathrm{U}$, material specifically analyzed for but not detected; PD, concentration of one CFC tracer less than expected by other data, indicating sample probably degraded for the purposes of age dating]

\begin{tabular}{|c|c|c|c|c|c|c|c|c|c|}
\hline \multirow{2}{*}{$\begin{array}{l}\text { Field } \\
\text { identifier } \\
\text { (fig. 8) }\end{array}$} & \multirow{2}{*}{$\begin{array}{l}\text { Sample date } \\
\text { (month/ day/ } \\
\text { year) }\end{array}$} & \multicolumn{2}{|c|}{ Dissolved gases } & \multicolumn{2}{|c|}{$\begin{array}{l}\text { Calculated from } \\
\text { dissolved gases }\end{array}$} & \multicolumn{3}{|c|}{$\begin{array}{c}\text { Calculated atmospheric mixing } \\
\text { ratio corrected for excess air and } \\
\text { recharge temperature }\end{array}$} & \multirow{2}{*}{ Apparent age from CFC results } \\
\hline & & $\begin{array}{l}\text { Oxygen, } \\
\text { field, } \\
\mathrm{mg} / \mathrm{L}\end{array}$ & $\begin{array}{l}\text { Methane, } \\
\mathrm{mg} / \mathrm{L}\end{array}$ & $\begin{array}{c}\text { Recharge } \\
\text { temperature } \\
\left({ }^{\circ} \mathrm{C}\right)\end{array}$ & $\begin{array}{c}\text { Excess } \\
\mathrm{N}_{2} \\
(\mathrm{mg} / \mathrm{L})\end{array}$ & $\begin{array}{l}\text { CFC-11 } \\
\text { (pptv) }\end{array}$ & $\begin{array}{l}\text { CFC-12 } \\
\text { (pptv) }\end{array}$ & $\begin{array}{l}\text { CFC-113 } \\
\text { (pptv) }\end{array}$ & \\
\hline \multicolumn{10}{|c|}{ Dakota aquifer } \\
\hline D-W3 & $6 / 13 / 2000$ & .6 & $\mathrm{U}$ & 7 & 2 & 12 & 50 & 3 & Early to mid-1960s \\
\hline \multicolumn{10}{|c|}{ Elkhorn River Valley alluvial aquifer } \\
\hline E-EC2 & $6 / 15 / 2000$ & 0.5 & $\mathrm{U}$ & 14 & 10 & PD & 108 & 4 & Late $1960 \mathrm{~s}$ to $1970 \mathrm{~s}$ \\
\hline E-V1 & $6 / 15 / 2000$ & .1 & $\mathrm{U}$ & 10 & 3 & $\mathrm{PD}$ & 81 & 2 & Early to mid-1960s \\
\hline E-V3 & $6 / 15 / 2000$ & .5 & $\mathrm{U}$ & 18 & 13 & $\mathrm{PD}$ & 49 & 0 & Early to mid-1960s \\
\hline M-H3 & $6 / 13 / 2000$ & 2.4 & $\mathrm{U}$ & 11 & 2 & PD & 148 & 0 & Early 1970 s \\
\hline \multicolumn{10}{|c|}{ Platte River Valley alluvial aquifer } \\
\hline P-A1 & $5 / 31 / 2000$ & 0.7 & 0.039 & 12 & 0 & 7 & 18 & 0 & Mid-1950s \\
\hline P-A2 & $6 / 12 / 2000$ & .8 & .030 & 14 & 0 & 2 & 21 & 0 & Mid-1950s; possible mixture \\
\hline P-A3 & $6 / 12 / 2000$ & .6 & .016 & 12 & 2 & 7 & 34 & 0 & $\begin{array}{l}\text { Mid-to-late 1950s; possible } \\
\text { mixture }\end{array}$ \\
\hline P-S1 & $6 / 12 / 2000$ & 6.5 & $\mathrm{U}$ & 12 & 0 & 147 & 190 & 9 & Early 1970 s \\
\hline P-S3 & $6 / 12 / 2000$ & 3.5 & $\mathrm{U}$ & 14 & 5 & 104 & 136 & 10 & Early to mid-1970s \\
\hline \multicolumn{10}{|c|}{ Upland area alluvial aquifers } \\
\hline U-BA1 & $6 / 14 / 2000$ & 4.2 & $\mathrm{U}$ & 8 & 1 & 34 & 169 & 25 & Early 1970 s or possible mixture \\
\hline
\end{tabular}

groundwater ages might be slightly younger than measured in 2000 because at least a portion of the current samples would be from water that formerly was upgradient and, therefore, includes more recently recharged water than did the water samples collected in 2000 .

\section{Groundwater Quality}

From 1992 to 2009, groundwater samples were collected from 217 wells (191 network wells and 26 wells in well nests) in the PMRNRD for analysis of 36 analytes classified as major ions, nutrients, radionuclides, and trace elements (appendix 3), 71 analytes classified as pesticides and pesticide degradates (appendix 4), 85 analytes classified as VOCs (appendix 5), 16 analytes classified as explosives compounds (appendix 6), and 3 stable isotopes ratios (appendix 7). All environmental sample results are provided in appendix 2.

\section{Depth to Water and Well Characteristics}

The median depth to water in 2009 for all sampled network wells and for one randomly selected well in each of the well nests was $15 \mathrm{ft}$ (table 8). The median depth to water was greater in the upland area alluvial aquifers than in the other aquifers (fig. 10A). Well characteristics including depth to the top of the uppermost screened interval, screen length, and well depth were compiled, if available, for the sampled wells generally prior to the first time the well was sampled (appendix 1). For all sampled network wells and for one randomly selected well in each of the well nests, the median depth to the top of the uppermost screen was $61 \mathrm{ft}$ (table 8); the median depth to the top of the uppermost screen was greater for wells in the Dakota aquifer than for the other aquifers (fig. 10B). For all sampled network wells and for one randomly selected well in each of the well nests, the median well depth was $95 \mathrm{ft}$ (table 8); the median well depth was greater in the Dakota aquifer than in the other aquifers (fig. 10D). 
Table 8. Summary statistics for well characteristics and depth to water in selected wells and field measurements from the most recent summer-to-fall samples from selected wells, Papio-Missouri River Natural Resources District, eastern Nebraska, 1992-2009.

[All depths in feet below land surface. $\mathrm{ft}$, feet; $\mathrm{mg} / \mathrm{L}$, milligrams per liter; $<$, less than; $\mu \mathrm{S} / \mathrm{cm}$, microsiemens per centimeter; ${ }^{\circ} \mathrm{C}$, degrees Celsius; Well construction information from Nebraska Department of Natural Resources (2010)]

\begin{tabular}{|c|c|c|c|c|c|c|c|c|}
\hline \multirow{2}{*}{ Characteristic or property } & \multirow{2}{*}{$\begin{array}{c}\text { Number of wells } \\
\text { or samples with } \\
\text { information }\end{array}$} & \multirow[b]{2}{*}{ Minimum } & \multicolumn{5}{|c|}{ Value at percentile indicated } & \multirow{2}{*}{ Maximum } \\
\hline & & & 10th & 25th & 50th & 75th & 90th & \\
\hline \multicolumn{9}{|c|}{$\begin{array}{l}\text { Well characteristics and depth to water for all sampled network wells and } \\
\text { for one randomly selected well in each well nest }\end{array}$} \\
\hline Depth to water, ft, 2009 & 167 & 2 & 6 & 9 & 15 & 38 & 128 & 250 \\
\hline $\begin{array}{l}\text { Depth to top of uppermost } \\
\text { screened interval, } \mathrm{ft}\end{array}$ & 149 & 9 & 19 & 36 & 61 & 104 & 198 & 535 \\
\hline Screen length, $\mathrm{ft}$ & 149 & 5 & 8 & 10 & 28 & 40 & 55 & 91 \\
\hline Well depth, ft & 182 & 26 & 46 & 62 & 95 & 149 & 247 & 565 \\
\hline \multicolumn{9}{|c|}{$\begin{array}{l}\text { Field measurements from the most recent summer-to-fall samples from the network wells and } \\
\text { from one randomly selected well in each well nest }\end{array}$} \\
\hline $\mathrm{pH}$, standard units & 195 & 6.6 & 6.9 & 7.0 & 7.1 & 7.3 & 7.6 & 8.0 \\
\hline Dissolved oxygen, mg/L & 191 & $<.1$ & $<.1$ & .1 & .9 & 4.8 & 7.2 & 15.3 \\
\hline $\begin{array}{l}\text { Specific conductance, } \mu \mathrm{S} / \mathrm{cm} \\
\text { at } 25^{\circ} \mathrm{C}\end{array}$ & 193 & 342 & 484 & 541 & 658 & 860 & 1,200 & 1,800 \\
\hline Water temperature, ${ }^{\circ} \mathrm{C}$ & 196 & 9.0 & 11.6 & 12.0 & 12.5 & 13.5 & 15.0 & 24.0 \\
\hline
\end{tabular}

\section{Field Measurements}

Measurements of $\mathrm{pH}$, dissolved oxygen, specific conductance, and water temperature were made onsite prior to sampling. The field measurement results for $\mathrm{pH}$, dissolved oxygen, specific conductance, and water temperature in the most recent summer-to-fall samples in the network wells and in one randomly selected well in each of the well nests from 1992 to 2009 when nitrates were also measured (hereafter referred to as the field-measurements samples, 1992 to 2009) are discussed below.

The hydrogen ion concentration in water, indicated by $\mathrm{pH}$, directly affects the solubility of metals. Highly acidic water (low $\mathrm{pH}$ ) and highly basic water (high $\mathrm{pH}$ ) can corrode pipes and may result in an unpleasant taste and appearance (World Health Organization, 2008). The USEPA SDWR recommends a $\mathrm{pH}$ of drinking water between 6.5 and 8.5 standard units (U.S. Environmental Protection Agency, 2009a). None of the field-measurements samples, 1992 to 2009 , had $\mathrm{pH}$ values outside this recommended range. The field measurements of $\mathrm{pH}$ for most (80 percent) field-measurements samples, 1992 to 2009 , ranged from 6.9 to 7.6 , with a median value of 7.1 (table 8). Median $\mathrm{pH}$ was greater in the Platte River Valley alluvial aquifer than in the other aquifers (fig. 11).

The field measurements of dissolved oxygen in most (80 percent) of the field-measurements samples, 1992 to 2009, ranged from less than 0.1 to $7.2 \mathrm{mg} / \mathrm{L}$; the dissolved oxygen concentration in all these samples ranged from less than 0.1 to
$15.3 \mathrm{mg} / \mathrm{L}$ (table 8). Dissolved oxygen was less than $0.5 \mathrm{mg} / \mathrm{L}$ in 43 percent of the samples, indicating anoxic conditions were frequently observed. The distribution of anoxic samples by aquifer varied - Dakota aquifer, 23 percent; Elkhorn River Valley alluvial aquifer, 48 percent; Missouri River Valley alluvial aquifer, 61 percent; Platte River Valley alluvial aquifer, 44 percent; upland area alluvial aquifers, 33 percent. Overall median dissolved oxygen concentration was $0.9 \mathrm{mg} / \mathrm{L}$. The median dissolved oxygen concentrations in samples from the Dakota and upland area alluvial aquifers were greater than the median concentrations in the samples from the Elkhorn, Missouri, and Platte River Valley alluvial aquifers (fig. 11B).

Dissolved oxygen concentrations in groundwater can help to predict the type of reduction-oxidation (redox) reactions that occur in groundwater. Microorganisms in groundwater utilize redox processes for energy. Typically, the most common electron donor available in aquifer systems is organic carbon in its dissolved and particulate forms. Under oxic conditions (dissolved oxygen concentrations of $0.5 \mathrm{mg} / \mathrm{L}$ or more), the most common electron acceptor is dissolved oxygen. Under anoxic conditions, the favored electron acceptors, in the order preferred by microorganisms and in descending order of energy yield, are nitrate, manganese (IV), ferric iron, sulfate, and carbon dioxide (McMahon and others, 2009).

Redox reactions can positively or negatively affect the quality of groundwater. Redox processes can alternately mobilize or immobilize potentially toxic metals, such as arsenic, which are associated with naturally occurring aquifer 

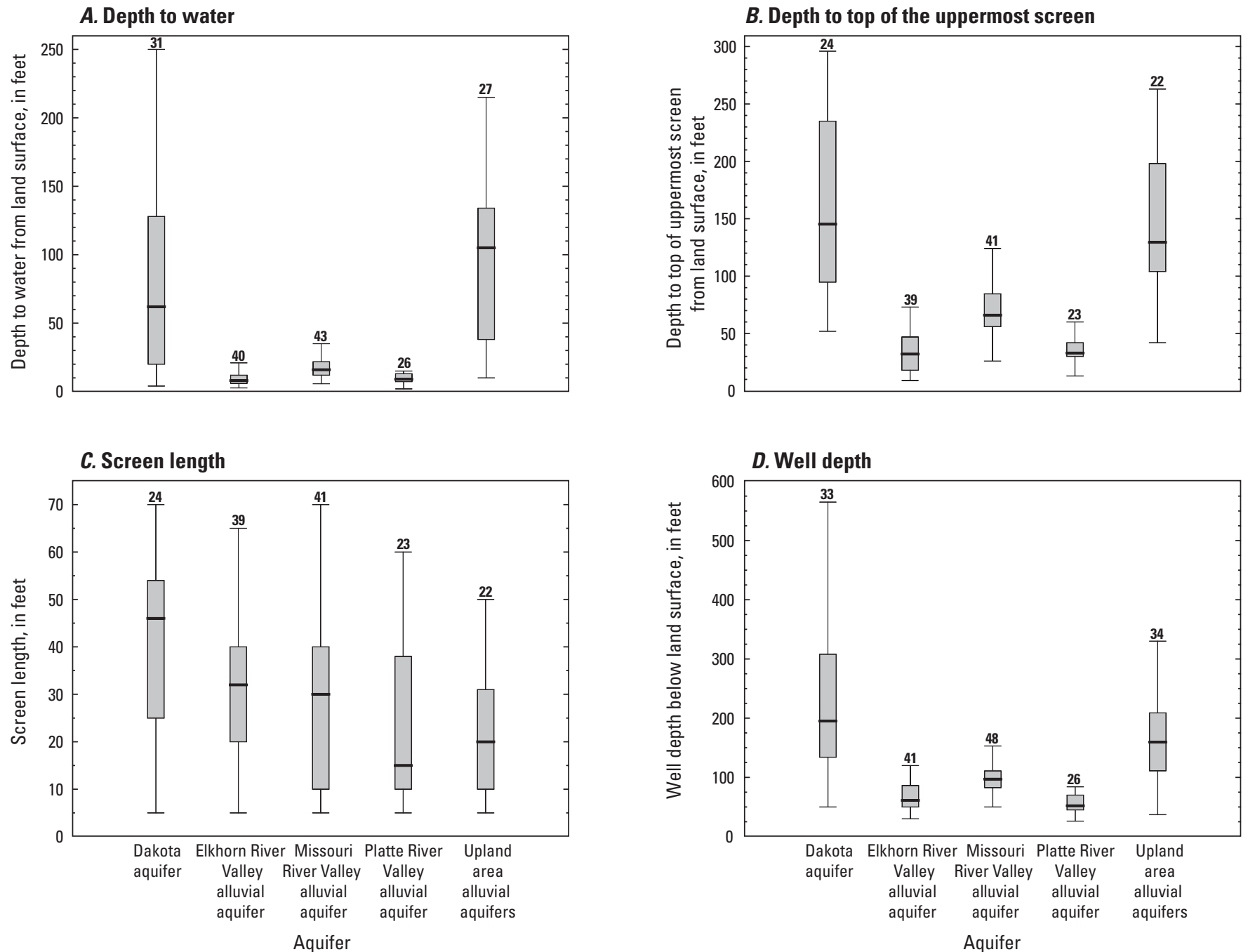

EXPLANATION

Depth to water and well characteristics

of selected wells, 1992-2009-The selected wells

are network wells and one randomly selected well

in each well nest with samples collected in summer

or fall for analysis of nitrate plus nitrite as nitrogen

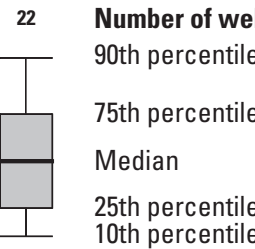

Figure 10. Distribution of $A$, depth to water, $B$, depth to the top of the uppermost screen, $C$, screen length, and $D$, well depth of selected wells, Papio-Missouri River Natural Resources District, eastern Nebraska, 1992-2009. 

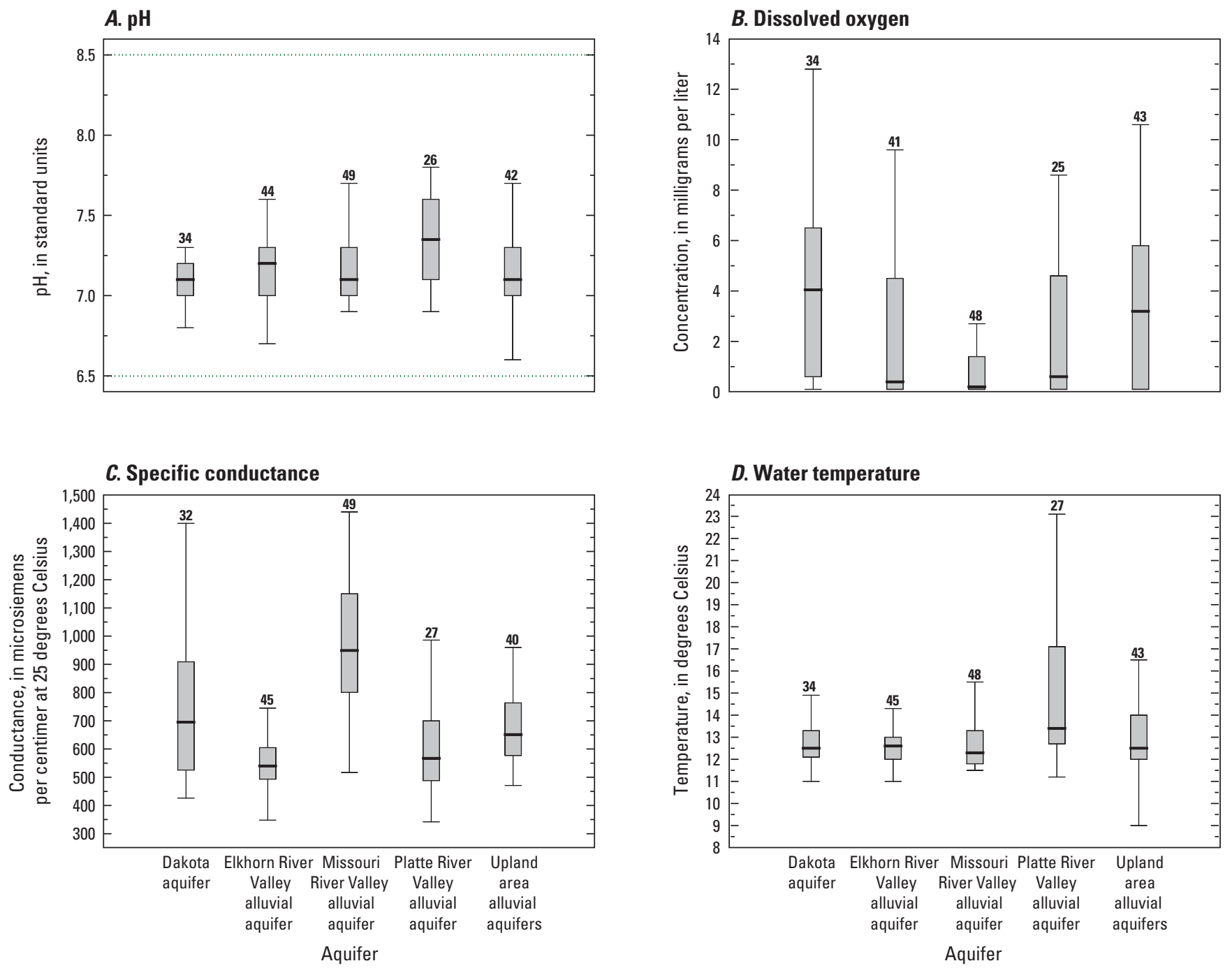

\section{EXPLANATION}

Frequency distribution of results from selected samples,1992-2009-The selected samples are the most recent samples collected in summerto-fall for analysis of nitrate plus nitrite as nitrogen from the network wells and one randomly selected well in each of the nine well nests

49

\section{Number of samples}

90th percentile

75th percentile

Median

25th percentile 10th percentile

Figure 11. Distribution of $A, \mathrm{pH}, B$, dissolved oxygen, $C$, specific conductance, and $D$, water temperature in selected samples, Papio-Missouri River Natural Resources District, eastern Nebraska, 1992-2009.

Drinking-water non-health guideline

(U.S. Environmental Protection

Agency, 2009a)

Secondary Drinking Water Regulation 
materials; contribute to the degradation or preservation of man-made contaminants, such as VOCs and pesticides; and generate or mobilize undesirable chemicals, such as dissolved manganese, ferrous iron, hydrogen sulfide, and methane. Other byproducts of the redox processes are nitrogen and hydrogen gases (Chapelle and others, 1995; McMahon and others, 2009).

Oxygen reduction has consistently been the predominant redox process in only three of the wells in two of the well nests (D-T3, P-S2, and P-S1). In five wells in the well nests (D-T1, D-T2, E-V1, E-V2, and E-V3) nitrate reduction is indicated in addition to other redox processes. In the remaining wells, the dominant redox processes are manganese, iron, or sulfate reduction under anoxic conditions or oxygen and manganese, iron, or sulfate reduction under mixed oxic-anoxic conditions (table 9).

Specific conductance is a measure of the water's ability to conduct electric current, which results from the presence of dissolved ions in the water (Hem, 1985). Because the electrical conductance varies with temperature, specific conductance measurements are reported relative to a standard temperature $\left(25^{\circ} \mathrm{C}\right)$. Specific conductance for most ( 80 percent) of the field-measurements samples, 1992 to 2009, ranged from 484 to 1,200 microsiemens per centimeter at $25^{\circ} \mathrm{C}$ (table 8). The median specific conductance was greater in the Missouri River Valley alluvial aquifer than in the other four aquifers (fig. 11C).

Groundwater temperature, which is approximately equal to mean annual air temperature, can affect chemical reactions (Hem, 1985). The water temperature for most (80 percent) of the field-measurements samples, 1992 to 2009 , ranged from 11.6 to $15.0^{\circ} \mathrm{C}$; median water temperature was $12.5^{\circ} \mathrm{C}$ (table 8 ). The median water temperature in the Platte River Valley alluvial aquifer $\left(13.4^{\circ} \mathrm{C}\right)$ was greater than in the other aquifers (fig. $11 D$ ) and had the greatest range of $11.2^{\circ} \mathrm{C}$ to $24.0^{\circ} \mathrm{C}$.

\section{Major lons}

Major ions analyzed in groundwater samples from the PMRNRD (appendix 3) included the positively charged ions (cations) calcium, magnesium, sodium, and potassium, and the negatively charged ions (anions) bicarbonate (generally referred to in this report as acid-neutralizing capacity), chloride, fluoride, nitrate, and sulfate. Silica, an uncharged species, also was included in major-ion analysis. Figure 12 presents, by aquifer, major-ion compositions for the most recent samples collected in the PMRNRD from 1992 to 2009, including all samples from wells in well nests. In the samples analyzed for this study, the predominant water type was calcium bicarbonate (fig. 12A-E). In three samples from network wells in the Dakota aquifer (D-001, D-002, D-003), the water type was predominantly a calcium sulfate. The wells in each well nest generally had similar ionic compositions; the exception was well M-H1 (the deep well in the well nest near Homer, Nebr.) that had a substantially higher sulfate concentration and lower carbonate plus bicarbonate concentration than wells $\mathrm{M}-\mathrm{H} 2$ and
M-H3 (the medium-depth and shallow wells in the well nest, respectively).

The selected samples discussed in the remainder of this section are the most recent samples with a major ions determination collected from network wells and one randomly selected well from each well nest. The major ion results from these samples indicate that concentrations of sulfate in four samples exceeded the USEPA SDWR and Nebraska Title118 standards, and concentrations of sodium in four samples exceeded USEPA nonenforceable Drinking Water Advisory Table (DWAT) standards (table 10; appendix 2). In addition, the chloride concentration in one sample exceeded 50 percent of the USEPA SDWR, and the fluoride concentration in one sample exceeded 30 percent of the USEPA MCL and Nebraska Title-118 standard. The concentrations of major ions, calcium and magnesium, were used to calculate "hardness;" water from all samples is considered "hard" [121 to $180 \mathrm{mg} / \mathrm{L}$ as calcium carbonate $\left(\mathrm{CaCO}_{3}\right)$ ] to "very hard" (greater than $180 \mathrm{mg} / \mathrm{L}$ as $\mathrm{CaCO}_{3}$ ) (Durfor and Becker, 1964).

\section{Sulfate}

Concentrations of sulfate in most ( 80 percent) of the samples from selected samples ranged from 17 to $200 \mathrm{mg} / \mathrm{L}$ (table 10), which is less than the USEPA SDWR and Nebraska Title-118 standard of $250 \mathrm{mg} / \mathrm{L}$ (appendix 3). Overall, sulfate concentrations ranged from 0.80 to $590 \mathrm{mg} / \mathrm{L}$. The concentration of sulfate was greater than the USEPA SDWR in samples from four wells (D-001, D-002, D-003, and M-H1). Water with high sulfate concentrations tends toward scale deposition when heated, can have an unpleasant taste, and may cause gastrointestinal effects (World Health Organization, 2008). In the Dakota, Platte River Valley alluvial, and upland area alluvial aquifers, concentrations of sulfate correlated positively with specific conductance (tau $=0.618$ to $0.667 ; p<0.05$ ).

\section{Sodium}

Sodium concentration was greater than the lower range of USEPA DWAT range of 30 to $60 \mathrm{mg} / \mathrm{L}$ in 39 percent of the samples. Sodium concentration was greater than the USEPA DWAT of $20 \mathrm{mg} / \mathrm{L}$ for people on low sodium diets in 69 percent of the samples.

\section{Chloride}

Chloride concentrations in water from most samples (80 percent) ranged from 2.0 to $43.0 \mathrm{mg} / \mathrm{L}$. The maximum chloride concentration was $210 \mathrm{mg} / \mathrm{L}$, which is less than the USEPA SDWR of $250 \mathrm{mg} / \mathrm{L}$ (table 10). Water with high chloride can have an unpleasant taste (World Health Organization, 2008). Chloride concentrations were positively correlated with specific conductance for samples from the Dakota aquifer ( $\operatorname{tau}=0.909, p=0.0001)$; correlations for the other aquifers were not significant $(p>0.05)$. 
Table 9. Range of oxidation-reduction classifications, by well, for samples from selected wells in well nests, Papio-Missouri River Natural Resources District, eastern Nebraska, 1999-2009.

$\left[\mathrm{O}_{2}\right.$, dissolved oxygen; $\mathrm{NO}_{3}^{-}$, dissolved nitrate; $\mathrm{Mn}(\mathrm{IV})$, oxidized manganese; $\mathrm{Fe}(\mathrm{III})$, ferric iron; $\mathrm{SO}_{4}^{2-}$, dissolved sulfate; Med-depth, medium-depth; --, not applicable $]$

\begin{tabular}{|c|c|c|c|c|c|c|c|c|c|c|}
\hline \multirow{3}{*}{$\begin{array}{c}\text { Well } \\
\text { identifier } \\
\text { (fig. 8) }\end{array}$} & \multirow{3}{*}{$\begin{array}{l}\text { Well screen } \\
\text { depth in } \\
\text { aquifer }\end{array}$} & \multirow{3}{*}{$\begin{array}{c}\text { Number } \\
\text { of } \\
\text { samples }\end{array}$} & \multicolumn{8}{|c|}{ Percentage of samples } \\
\hline & & & \multirow{2}{*}{$\begin{array}{c}\text { Oxic conditions } \\
\mathbf{O}_{2} \text { reduction }\end{array}$} & \multirow[b]{2}{*}{$\begin{array}{c}\text { Suboxic } \\
\text { conditions }^{1}\end{array}$} & \multicolumn{4}{|c|}{ Anoxic conditions } & \multicolumn{2}{|c|}{ Mixed oxic-anoxic } \\
\hline & & & & & $\begin{array}{c}\mathrm{NO}_{3}^{-} \\
\text {reduction }\end{array}$ & $\begin{array}{l}\mathrm{Mn}(\mathrm{IV}) \\
\text { reduction }\end{array}$ & $\begin{array}{l}\mathrm{Fe}(\mathrm{III}) / \mathrm{SO}_{4}^{2-} \\
\text { reduction }\end{array}$ & $\begin{array}{l}\mathrm{NO}_{3} \text { and } \mathrm{Mn}(\mathrm{IV}) \\
\text { reduction }\end{array}$ & $\begin{array}{l}\mathrm{O}_{2} \text { and } \mathrm{Mn}(\mathrm{IV}) \\
\text { reduction }\end{array}$ & $\begin{array}{c}\mathrm{O}_{2} \text { and } \mathrm{Fe}(\mathrm{III}) / \mathrm{SO}_{4}{ }^{2} \\
\text { reduction }\end{array}$ \\
\hline \multicolumn{11}{|c|}{ Dakota aquifer } \\
\hline D-T3 & Shallow & 11 & 100 & -- & -- & -- & -- & -- & -- & -- \\
\hline D-T2 & Med-depth & 11 & -- & -- & -- & 18 & 9 & 18 & 55 & -- \\
\hline D-T1 & Deep & 11 & -- & -- & -- & 36 & -- & 9 & 55 & -- \\
\hline D-W3 & Shallow & 11 & -- & -- & -- & -- & 64 & -- & -- & 36 \\
\hline D-W2 & Med-depth & 11 & -- & -- & -- & -- & 45 & -- & -- & 55 \\
\hline D-W1 & Deep & 11 & -- & -- & -- & -- & 100 & -- & -- & -- \\
\hline \multicolumn{11}{|c|}{ Elkhorn River Valley alluvial aquifer } \\
\hline E-EC2 & Shallow & 11 & -- & -- & -- & -- & 9 & -- & -- & 91 \\
\hline E-EC1 & Deep & 11 & -- & -- & -- & -- & 45 & -- & -- & 55 \\
\hline E-V3 & Shallow & 11 & -- & -- & -- & 9 & -- & 36 & 55 & -- \\
\hline E-V2 & Med-depth & 11 & -- & 9 & -- & 45 & -- & 36 & 9 & -- \\
\hline E-V1 & Deep & 11 & 27 & 36 & 36 & -- & -- & -- & -- & -- \\
\hline \multicolumn{11}{|c|}{ Missouri River Valley alluvial aquifer } \\
\hline M-BC3 & Shallow & 11 & -- & -- & -- & -- & 18 & -- & -- & 82 \\
\hline $\mathrm{M}-\mathrm{BC} 2$ & Med-depth & 11 & -- & -- & -- & -- & 82 & -- & -- & 18 \\
\hline $\mathrm{M}-\mathrm{BC} 1$ & Deep & 12 & -- & -- & -- & -- & 92 & -- & -- & 8 \\
\hline M-H3 & Shallow & 10 & -- & -- & -- & -- & 20 & -- & -- & 80 \\
\hline M-H2 & Med-depth & 10 & -- & -- & -- & -- & 30 & -- & -- & 70 \\
\hline M-H1 & Deep & 10 & -- & -- & -- & -- & 80 & -- & -- & 20 \\
\hline \multicolumn{11}{|c|}{ Platte River Valley alluvial aquifer } \\
\hline P-A3 & Shallow & 11 & -- & -- & -- & -- & 64 & -- & -- & 36 \\
\hline P-A2 & Med-depth & 11 & -- & -- & -- & -- & 36 & -- & -- & 64 \\
\hline P-A1 & Deep & 11 & -- & -- & -- & -- & 82 & -- & -- & 18 \\
\hline $\mathrm{P}-\mathrm{S} 3$ & Shallow & 12 & -- & -- & -- & -- & -- & -- & 8 & 92 \\
\hline P-S2 & Med-depth & 12 & 100 & -- & -- & -- & -- & -- & -- & -- \\
\hline P-S1 & Deep & 12 & 100 & -- & -- & -- & -- & -- & -- & -- \\
\hline \multicolumn{11}{|c|}{ Upland area alluvial aquifers } \\
\hline U-BA3 & Shallow & 4 & -- & -- & -- & -- & -- & -- & 75 & 25 \\
\hline U-BA2 & Med-depth & 9 & -- & -- & -- & -- & -- & -- & -- & 100 \\
\hline U-BA1 & Deep & 11 & -- & -- & -- & -- & -- & -- & -- & 100 \\
\hline
\end{tabular}

${ }^{1}$ Further definition of the oxidation-reduction processes not feasible. 


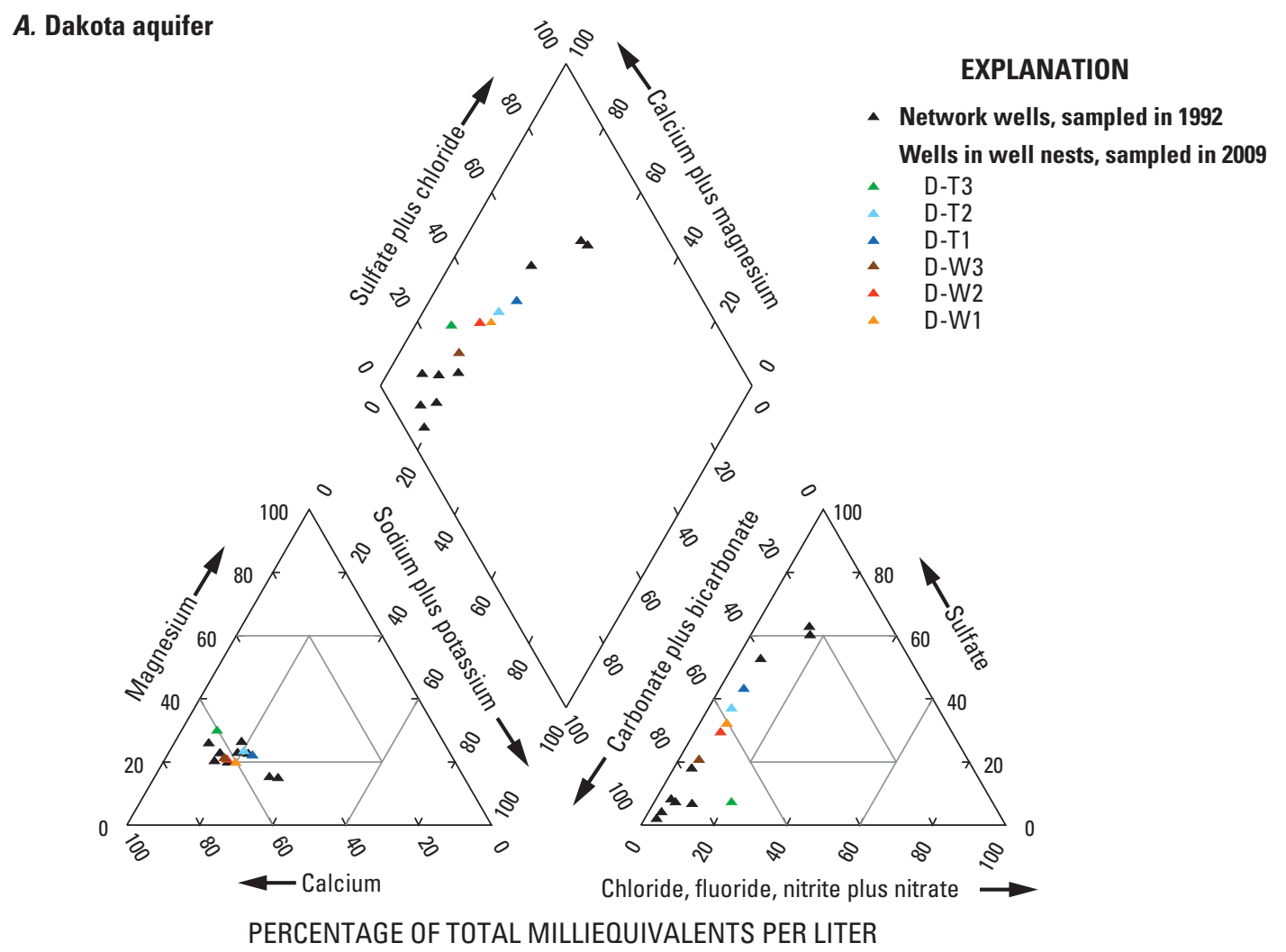

B. Elkhorn River Valley alluvial aquifer

\section{EXPLANATION}

- Network wells, sampled in 1992

Wells in well nests, sampled in 2008 to 2009

E-EC2

- E-EC1

$\triangle \quad E-V 3$

$\Delta \quad \mathrm{E}-\mathrm{V} 2$

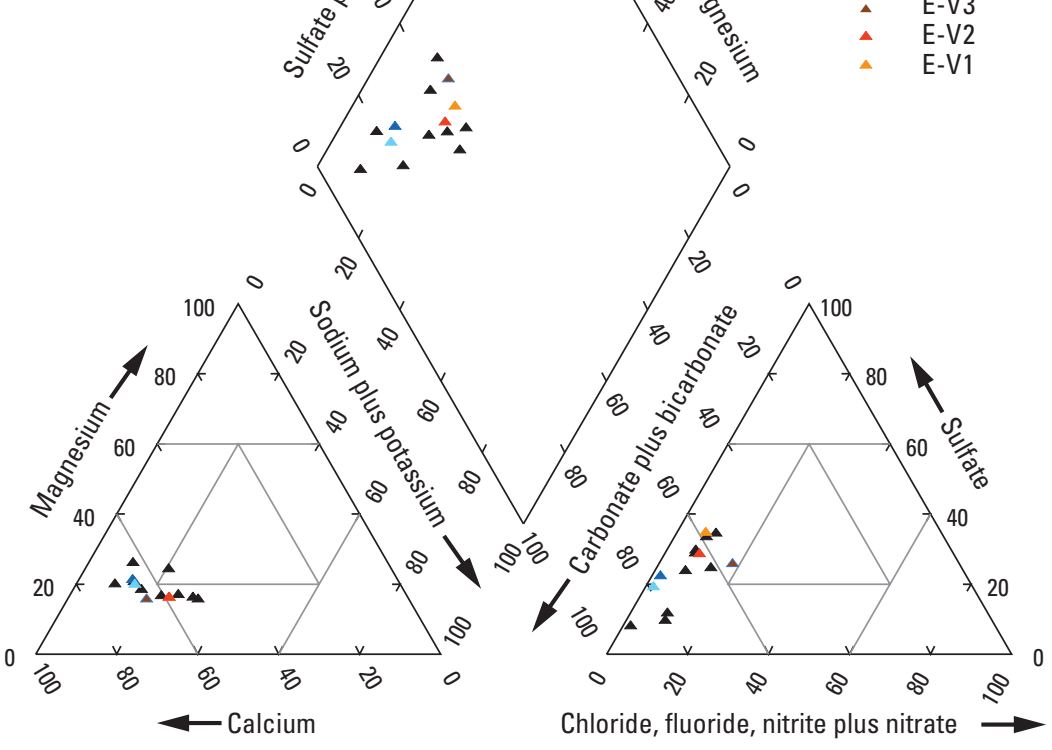

PERCENTAGE OF TOTAL MILLIEQUIVALENTS PER LITER

Figure 12. Ionic composition of groundwater in the $A$, Dakota aquifer, $B$, Elkhorn River Valley alluvial aquifer, $C$, Missouri River Valley alluvial aquifer, D, Platte River Valley alluvial aquifer, and $E$, upland area alluvial aquifers, in the most recent samples in network wells and all wells in the well nests, Papio-Missouri River Natural Resources District, eastern Nebraska, 1992-2009. 
C. Missouri River Valley alluvial aquifer

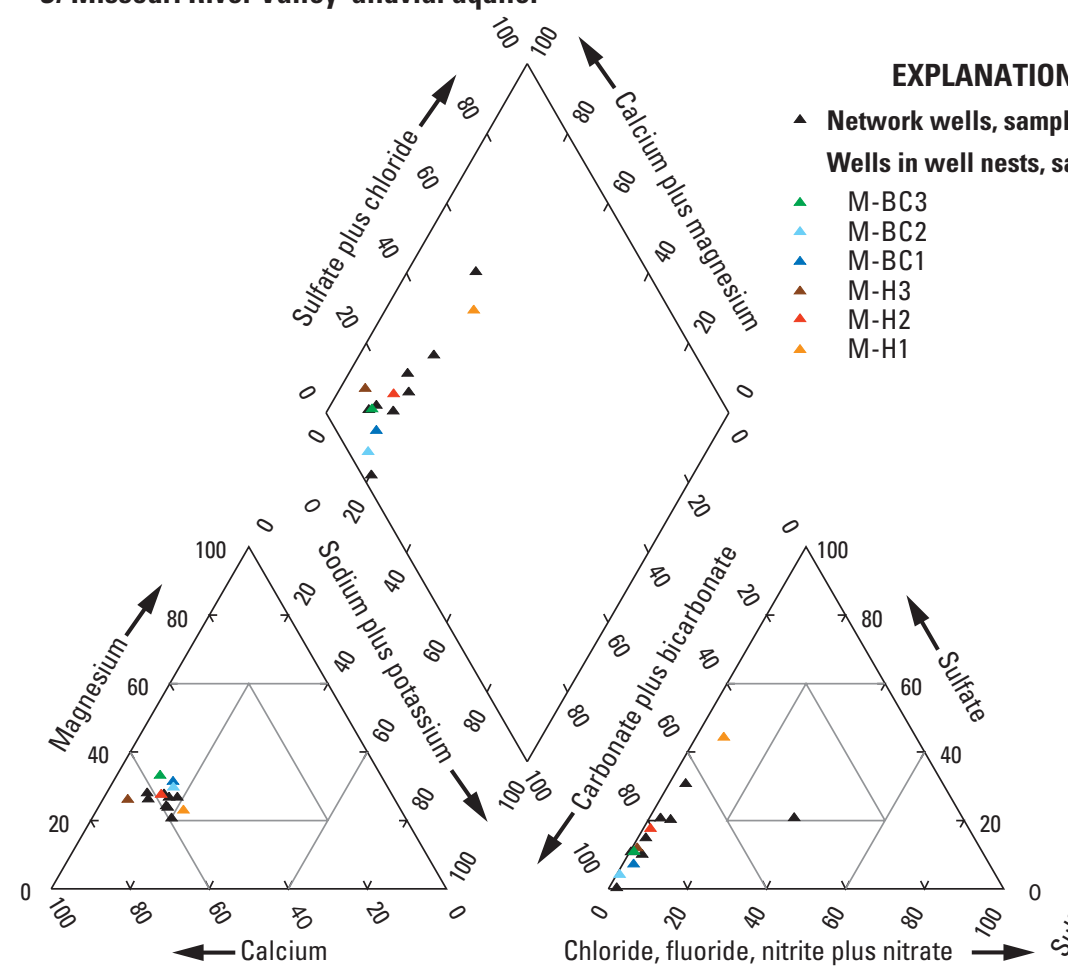

PERCENTAGE OF TOTAL MILLIEQUIVALENTS PER LITER

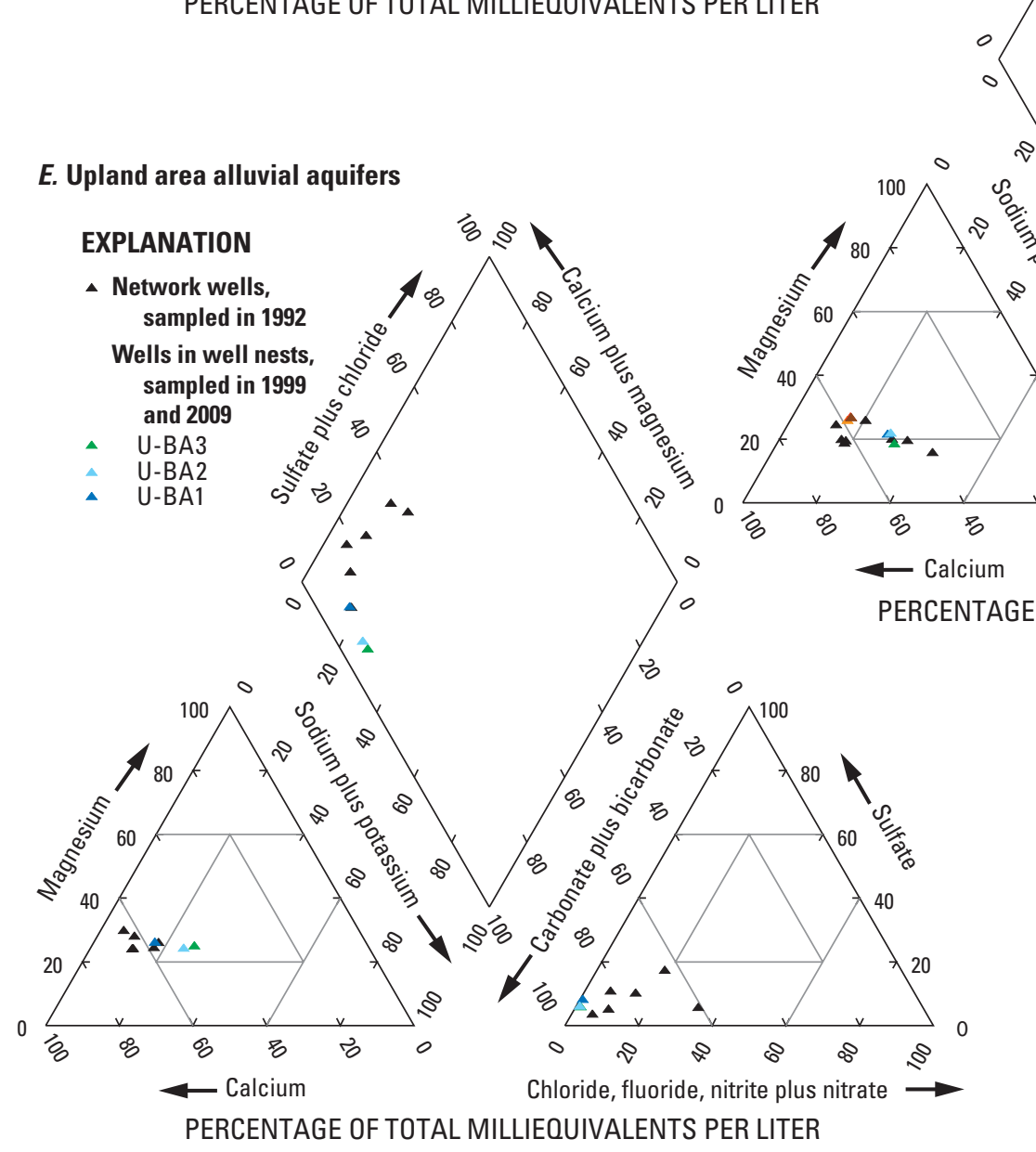

Figure 12. Ionic composition of groundwater in the $A$, Dakota aquifer, $B$, Elkhorn River Valley alluvial aquifer, $C$, Missouri River Valley alluvial aquifer, $D$, Platte River Valley alluvial aquifer, and $E$, upland area alluvial aquifers, in the most recent samples in network wells and all wells in the well nests, Papio-Missouri River Natural Resources District, eastern Nebraska, 1992-2009.-Continued 
Table 10. Summary statistics for major ions, hardness, silica, and nutrients in the most recent selected groundwater samples collected in the network wells and in one randomly selected well in each well nest, Papio-Missouri River Natural Resources District, eastern Nebraska, $1992-2009$.

[USGS, U.S. Geological Survey; LRL, laboratory reporting limit; mg/L, milligrams per liter; USEPA, U.S. Environmental Protection Agency; CaCO Secondary Drinking Water Regulation; MCL, Maximum Contaminant Level; DWAT, Drinking Water Advisory Table; DWAT-Low sodium diet, Drinking Water Advisory Table maximum concentration for individuals on a restricted sodium diet; Reserved, a standard will be promulgated for this analyte; N, nitrogen; P, phosphorus; <, less than]

\begin{tabular}{|c|c|c|c|c|c|c|c|c|c|c|c|c|c|}
\hline \multirow{2}{*}{$\begin{array}{l}\text { Name of major ion } \\
\text { or nutrient }\end{array}$} & \multirow{2}{*}{$\begin{array}{l}\text { USGS } \\
\text { paramenter } \\
\text { code }\end{array}$} & \multirow{2}{*}{$\begin{array}{l}\text { Highest LRL, } \\
1992 \text { to } 2009^{1} \text {, } \\
\text { mg/L }\end{array}$} & \multirow{2}{*}{$\begin{array}{l}\text { Number } \\
\text { of } \\
\text { samples }\end{array}$} & \multirow{2}{*}{$\begin{array}{c}\text { Number } \\
\text { of } \\
\text { detections }\end{array}$} & \multicolumn{7}{|c|}{ Concentration, in mg/L } & \multirow{2}{*}{$\begin{array}{l}\text { USEPA drinking-water } \\
\text { standard(s)/type of } \\
\text { standard², mg/L }\end{array}$} & \multirow{2}{*}{$\begin{array}{c}\text { Nebraska } \\
\text { Title-118 } \\
\text { standard }^{3} \\
\text { mg/L }\end{array}$} \\
\hline & & & & & Minimum & $\begin{array}{c}\text { 10th } \\
\text { percentile }\end{array}$ & $\begin{array}{c}\text { 25th } \\
\text { percentile }\end{array}$ & Median & $\begin{array}{c}\text { 75th } \\
\text { percentile }\end{array}$ & $\begin{array}{c}\text { 90th } \\
\text { percentile }\end{array}$ & Maximum & & \\
\hline \multicolumn{14}{|c|}{ Major lons results for anions in the most recent selected samples } \\
\hline $\begin{array}{l}\text { Acid neutralizing capacity, } \\
\text { laboratory, as } \mathrm{CaCO}_{3}\end{array}$ & 90410 & 8 & 49 & 49 & 120 & 173 & 213 & 275 & 328 & 438 & 677 & -- & -- \\
\hline Chloride & 00940 & .33 & 49 & 49 & .80 & 2.0 & 6.3 & 15.0 & 19.0 & 43.0 & 210 & 250/SDWR & 250 \\
\hline Fluoride & 00950 & .17 & 49 & 49 & .2 & .2 & .3 & .3 & .4 & .8 & 1.8 & 4/MCL and 2/SDWR & 4 \\
\hline Sulfate & 00945 & .31 & 49 & 49 & .80 & 17.0 & 27.5 & 68.2 & 95.0 & 200 & 590 & $250 / \mathrm{SDWR}$ & 250 \\
\hline \multicolumn{14}{|c|}{ Major lons results for cations in the most recent selected samples } \\
\hline Calcium & 00915 & 0.04 & 50 & 50 & 47.0 & 55.0 & 68.0 & 93.0 & 118 & 171 & 210 & -- & -- \\
\hline Magnesium & 00925 & .02 & 50 & 50 & 9.80 & 12.0 & 16.0 & 19.5 & 29.0 & 44.0 & 56.0 & -- & -- \\
\hline Potassium & 00935 & .16 & 49 & 49 & 1.80 & 2.40 & 4.10 & 7.50 & 8.90 & 12.0 & 22.0 & -- & -- \\
\hline Sodium & 00930 & .2 & 50 & 50 & 7.60 & 17.0 & 20.0 & 26.0 & 37.0 & 61.7 & 140 & $\begin{array}{c}\text { 30-60/DWAT; } \\
\text { 20/DWAT-Low sodium } \\
\text { diet }\end{array}$ & Reserved \\
\hline \multicolumn{14}{|c|}{ Results for hardness, calculated from the most recent selected samples } \\
\hline Hardness, as $\mathrm{CaCO}_{3}$ & 00900 & -- & 51 & 51 & 167 & 196 & 237 & 317 & 412 & 637 & 741 & -- & -- \\
\hline \multicolumn{14}{|c|}{ Results for silica in the most recent selected samples } \\
\hline Silica & 00955 & 0.5 & 50 & 50 & 9.10 & 19.5 & 24.0 & 28.9 & 32.0 & 35.0 & 37.0 & -- & -- \\
\hline \multicolumn{14}{|c|}{ Nutrients results in the most recent selected summer-to-fall samples } \\
\hline Ammonia as $\mathrm{N}$ & 00608 & 0.04 & 113 & 57 & $<0.04$ & $<0.04$ & $<0.04$ & 0.08 & 0.41 & 1.04 & 1.81 & 30/DWAT & -- \\
\hline Nitrate plus nitrite as $\mathrm{N}$ & 00631 & .06 & 200 & 113 & $<.06$ & $<.06$ & $<.06$ & .12 & 2.89 & 8.55 & 74.6 & 10/MCL & 10 \\
\hline Nitrite as $\mathrm{N}$ & 00613 & .008 & 113 & 14 & $<.008$ & $<.008$ & $<.008$ & $<.008$ & $<.008$ & .022 & .088 & $1 / \mathrm{MCL}$ & 1 \\
\hline Orthophosphate as P & 00671 & .02 & 113 & 102 & $<.02$ & .03 & .06 & .11 & .18 & .25 & .89 & -- & -- \\
\hline
\end{tabular}

${ }^{1}$ Source: U.S. Geological Survey National Water Quality Laboratory, Denver, Colo.

${ }^{2}$ Source: U.S. Environmental Protection Agency, 2009a.

${ }^{3}$ Source: Nebraska Department of Environmental Quality, 2006. 


\section{Fluoride}

Fluoride concentrations ranged from 0.2 to $1.8 \mathrm{mg} / \mathrm{L}$ in the selected samples (table 10). Fluoride in low concentrations $(0.7$ to $1.2 \mathrm{mg} / \mathrm{L})$ can prevent tooth decay (Centers for Disease Control and Prevention, 2010), but concentrations in drinking water of about $4 \mathrm{mg} / \mathrm{L}$ or greater can lead to staining of teeth and cause bone damage (U.S. Environmental Protection Agency, 1985 and 2011). The USEPA MCL for fluoride in drinking water is $4 \mathrm{mg} / \mathrm{L}$; the USEPA SDWR for fluoride is $2 \mathrm{mg} / \mathrm{L}$. None of the selected samples had fluoride concentrations greater than USEPA drinking-water standards. For samples from the Dakota aquifer, concentrations of fluoride were positively correlated with specific conductance $(\operatorname{tau}=0.618$, $p=0.008$ ), which is consistent with the fact that fluoride in groundwater usually originates from the dissolution of minerals (Freeze and Cherry, 1979; Hem, 1985), and negatively correlated with dissolved oxygen ( $\operatorname{tau}=-0.709, p=0.002)$, possibly because groundwater is older in the Dakota aquifer than in the alluvial aquifers. Older waters are more likely to have high solute concentrations (Bartos and others, 2004) and less dissolved oxygen (DeSimone, 2009) than younger waters.

\section{Calcium, Magnesium, and Hardness}

Calcium concentration in water from most samples (80 percent) ranged from 55.0 to $171 \mathrm{mg} / \mathrm{L}$; the maximum calcium concentration was $210 \mathrm{mg} / \mathrm{L}$. Magnesium concentration in water from most samples ( 80 percent) ranged from 12.0 to $44.0 \mathrm{mg} / \mathrm{L}$; the maximum magnesium concentration was $56.0 \mathrm{mg} / \mathrm{L}$. Calcium and magnesium are the principal contributors to hardness. Hardness is a qualitative indicator of how readily water forms insoluble residues with soap and scale deposits when heated; water used for domestic purposes is generally considered "hard" when hardness is greater than $120 \mathrm{mg} / \mathrm{L}$ of $\mathrm{CaCO}_{3}$ (Hem, 1985). Hardness results for samples from all wells were greater than $120 \mathrm{mg} / \mathrm{L}$ of $\mathrm{CaCO}_{3}$ (table 10).

\section{Trace Elements}

Trace elements, which occur naturally in rocks, include metals and semimetallic elements that typically are found in groundwater at concentrations less than $1 \mathrm{mg} / \mathrm{L}$. A given trace element's concentration, oxidation state, species, and complexes in groundwater are determined by (1) the abundance of the element in aquifer materials, (2) geochemical conditions, such as redox conditions and $\mathrm{pH}$, (3) concentrations of other dissolved constituents, such as chloride, sulfate, and bicarbonate, and (4) attenuation processes, such as adsorption (Freeze and Cherry, 1979; Hem, 1985). The mobility, bioavailability, and toxicity of a given trace element can differ among the trace element's species (Hem, 1985).

Eighteen of the 21 trace elements analyzed in samples from PMRNRD wells (appendix 3) have USEPA drinking-water standards (U.S. Environmental Protection Agency, 2009a). Sixteen of the trace elements with USEPA standards were detected in the most recent samples collected from network wells and from one randomly selected well from each well nest (hereafter referred to as the selected trace-element samples; table 11). In the selected trace-element samples, the only trace-element concentration that exceeded an enforceable USEPA drinking-water standard (MCL) was for arsenic; this occurred in 4 percent of the samples. In the selected trace-element samples, trace elements detected at concentrations that exceeded a nonenforceable USEPA drinking-water standard (SDWR or LTHA) were iron (46 percent of samples), manganese ( 70 percent), and strontium ( 4 percent). Trace elements that were detected in the selected trace-element samples but did not have a USEPA drinking-water standard were cobalt, lithium, and vanadium. Mercury was detected in the selected samples, but it was also detected in the associated equipment- and field-blank samples at a similar concentration; therefore, the mercury detections likely were caused by contamination during sampling or processing. The only trace elements that were not detected in any of the selected samples were lead and nickel (table 11).

\section{Arsenic}

Arsenic in drinking water can contribute to skin, bladder, and lung cancers and has been associated with cardiovascular and neurological effects (National Research Council, 2001; World Health Organization, 2008). The USEPA MCL and the Nebraska Title-118 standard for arsenic are each 10 $\mu \mathrm{g} / \mathrm{L}$ (Nebraska Department of Environmental Quality, 2006; U.S. Environmental Protection Agency, 2009a, 2009b). Samples were analyzed for arsenic in 40 network wells (collected in 1992) and 21 wells in well nests (collected in 2008). The areal distribution of arsenic concentrations from the most recent results for all the 61 sampled wells is shown in figure 13; arsenic concentration was greater than the USEPA MCL and Nebraska Title-118 standard in samples from two of the wells.

In the selected trace-element samples, arsenic was detected in 37 of these samples-31 samples from 1992 and 6 samples from 2008. Among the selected samples, those from the Missouri River Valley alluvial aquifer had the highest median arsenic concentration $(5.4 \mu \mathrm{g} / \mathrm{L})$ and included the two samples with concentrations greater than $10 \mu \mathrm{g} / \mathrm{L}$ (fig. 14). Arsenic concentrations were significantly greater in the Missouri River Valley alluvial aquifer than in the Dakota $(p=0.001)$ and upland area alluvial $(p=0.012)$ aquifers but were not significantly greater than those from the Elkhorn River Valley ( $p=0.095$ ) or Platte River Valley alluvial aquifers $(p=0.325)$.

Previous studies found that the alluvial and glacial aquifers in the upper Midwest, which includes the PMRNRD, can contain high concentrations of aqueous arsenic (Ziegler and others, 1993; Welch and others, 2000). In a national study, the median concentration of arsenic in groundwater in Nebraska was estimated to be $4 \mu \mathrm{g} / \mathrm{L}$ (Focazio and others, 1999). 
Table 11. Summary statistics for trace elements in the most recent samples collected in network wells and in one randomly selected well in each well nest, Papio-Missouri River Natural Resources District, eastern Nebraska, 1992-2009.

[USGS, U.S. Geological Survey; LRL, laboratory reporting level; $\mu$ g/L, micrograms per liter; USEPA, U.S. Environmental Protection Agency; <, less than; MCL, Maximum Contaminant Level; LTHA, Lifetime Health Advisory level; --, no data or not defined; $<$ number $>/$ TT Action level, Treatment Technique required by public water systems if more than 10 percent of tap water samples exceed $<$ number $>$ concentration; SDWR, Secondary Drinking Water Regulation; V, value may be affected by contamination; Reserved, a standard will be promulgated for this analyte]

\begin{tabular}{|c|c|c|c|c|c|c|c|c|c|c|c|c|}
\hline \multirow[b]{2}{*}{ Trace element } & \multirow{2}{*}{$\begin{array}{l}\text { USGS } \\
\text { parameter } \\
\text { code }\end{array}$} & \multirow[b]{2}{*}{$\begin{array}{l}\text { Number of } \\
\text { samples }\end{array}$} & \multirow{2}{*}{$\begin{array}{c}\text { Number of } \\
\text { detections, using } \\
\text { maxiumum LRL, } \\
1992 \text { to } 2009\end{array}$} & \multicolumn{7}{|c|}{ Concentration, in $\mu \mathrm{g} / \mathrm{L}$} & \multirow{2}{*}{$\begin{array}{c}\text { USEPA drinking-water } \\
\text { standard(s)/type of standard', } \\
\mu \mathrm{g} / \mathrm{L}\end{array}$} & \multirow{2}{*}{$\begin{array}{c}\text { Nebraska } \\
\text { Title-118 } \\
\text { standard }^{2} \text {, } \\
\mu \mathrm{gg} / \mathrm{L}\end{array}$} \\
\hline & & & & Minimum & $\begin{array}{c}\text { 10th } \\
\text { percentile }\end{array}$ & $\begin{array}{c}\text { 25th } \\
\text { percentile }\end{array}$ & Median & $\begin{array}{c}\text { 75th } \\
\text { percentile }\end{array}$ & $\begin{array}{c}\text { 90th } \\
\text { percentile }\end{array}$ & Maximum & & \\
\hline Arsenic & 01000 & 49 & 37 & $<1$ & $<1$ & 1 & 2 & 4 & 8 & 14 & $10 / \mathrm{MCL}$ & 10 \\
\hline Barium & 01005 & 50 & 50 & 14 & 52 & 130 & 185 & 250 & 350 & 530 & $2,000 / \mathrm{MCL}$ & 2,000 \\
\hline Beryllium & 01010 & 50 & 10 & $<.5$ & $<.5$ & $<.5$ & $<.5$ & $<.5$ & .8 & .9 & 4/MCL & 4 \\
\hline Boron & 01020 & 49 & 49 & 30 & 50 & 56 & 70 & 170 & 370 & 730 & $1,000 /$ LTHA & 1,000 \\
\hline Cadmium & 01025 & 50 & 8 & $<1$ & $<1$ & $<1$ & $<1$ & $<1$ & 2 & 3 & 5/MCL & 5 \\
\hline Chromium & 01030 & 50 & 1 & $<5$ & $<5$ & $<5$ & $<5$ & $<5$ & $<5$ & 7 & 100/MCL & 100 \\
\hline Cobalt & 01035 & 50 & 5 & $<3$ & $<3$ & $<3$ & $<3$ & $<3$ & 3 & 12 & -- & -- \\
\hline Copper & 01040 & 50 & 5 & $<10$ & $<10$ & $<10$ & $<10$ & $<10$ & 10 & 210 & $\begin{array}{c}\text { 1,300/TT Action level and } \\
\text { 1,000 SDWR }\end{array}$ & 1,300 \\
\hline Iron & 01046 & 50 & 34 & $<10$ & $<10$ & $<10$ & 170 & 2,200 & 7,200 & 17,000 & 300/SDWR & -- \\
\hline Lead & 01049 & 50 & 0 & $<10$ & $<10$ & $<10$ & $<10$ & $<10$ & $<10$ & $<10$ & 15/TT Action level & 15 \\
\hline Lithium & 01130 & 50 & 50 & 8 & 13 & 17 & 21 & 52 & 79 & 190 & -- & -- \\
\hline Manganese & 01056 & 50 & 42 & $<1.0$ & $<1.0$ & 11 & 329 & 740 & 1,250 & 2,300 & 300/LTHA and 50/SDWR & 50 \\
\hline Mercury & 71890 & 10 & 7 & $<.01$ & $<.01$ & $<.01$ & V.02 & V.03 & V.06 & V.06 & $2 / \mathrm{MCL}$ & 2 \\
\hline Molybdenum & 01060 & 50 & 1 & $<10$ & $<10$ & $<10$ & $<10$ & $<10$ & $<10$ & 10 & 40/LTHA & Reserved \\
\hline Nickel & 01065 & 50 & 0 & $<10$ & $<10$ & $<10$ & $<10$ & $<10$ & $<10$ & $<10$ & 100/LTHA & Reserved \\
\hline Selenium & 01145 & 49 & 17 & $<1$ & $<1$ & $<1$ & $<1$ & 2 & 5 & 12 & $50 / \mathrm{MCL}$ & 50 \\
\hline Silver & 01075 & 50 & 10 & $<1$ & $<1$ & $<1$ & $<1$ & $<1$ & 2 & 3 & 100/LTHA and 100/SDWR & 100 \\
\hline Strontium & 01080 & 50 & 50 & 220 & 300 & 340 & 420 & 840 & 1,800 & 4,500 & 4,000/LTHA & -- \\
\hline Uranium & 22703 & 48 & 44 & $<.1$ & .1 & .6 & 1.8 & 3.8 & 6.7 & 7.7 & 30/MCL & 30 \\
\hline Vanadium & 01085 & 50 & 1 & $<6$ & $<6$ & $<6$ & $<6$ & $<6$ & $<6$ & 9 & -- & Reserved \\
\hline Zinc & 01090 & 50 & 38 & $<3$ & $<3$ & 3 & 6 & 12 & 42 & 460 & $2,000 /$ LTHA and 5,000/SDWR & 5,000 \\
\hline
\end{tabular}

${ }^{1}$ Source: U.S. Environmental Protection Agency, 2009a.

${ }^{2}$ Source: Nebraska Department of Environmental Quality, 2006. 


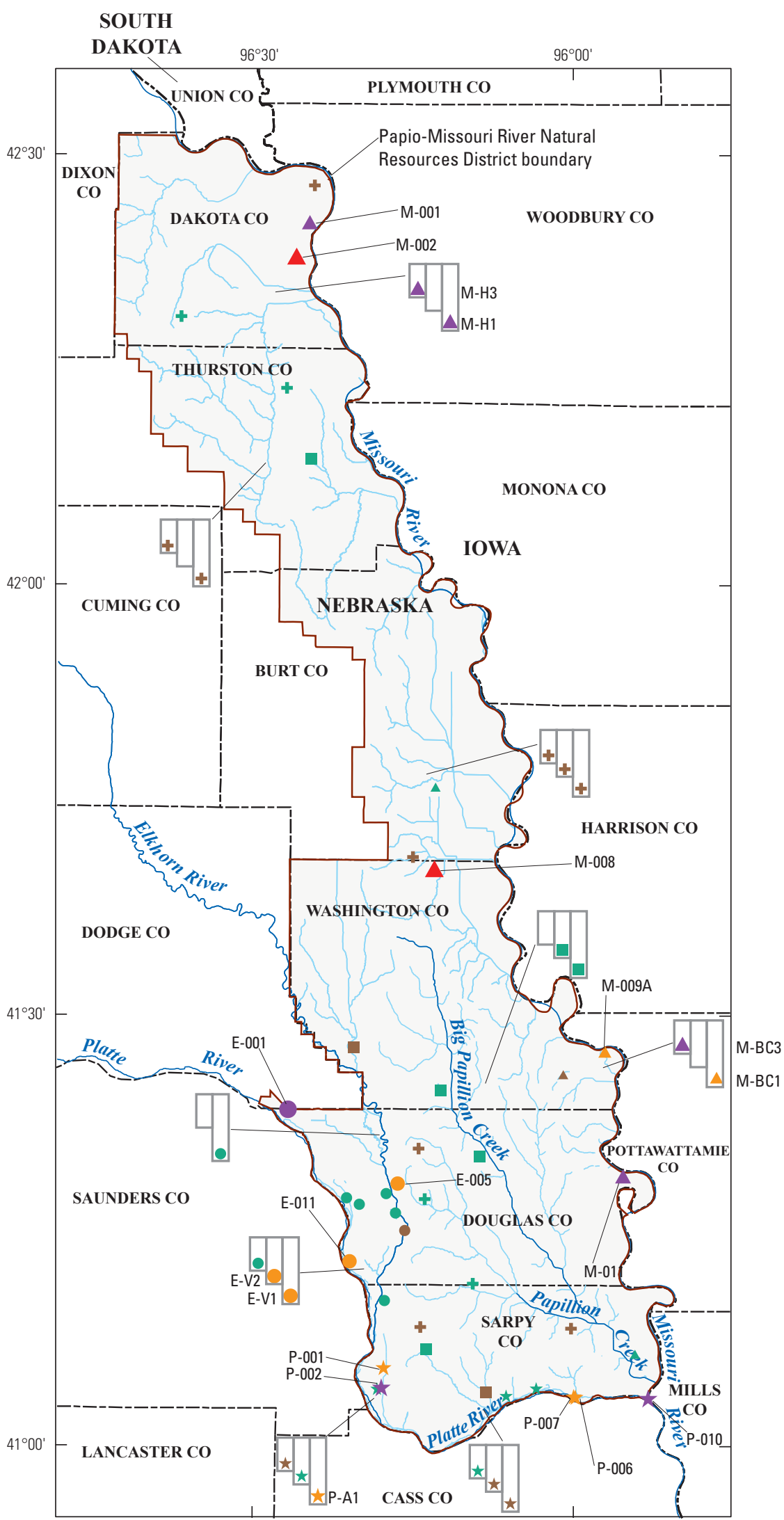

Base from U.S. Geological Survey digital data, 2001, 1:2,000,000 Albers Equal-Area Conic projection

Standard parallels $29^{\circ} 30^{\prime} \mathrm{N}$ and $45^{\circ} 40^{\prime} \mathrm{N}$

Central meridian $97^{\circ} 30^{\prime} \mathrm{W}$

North American Datum of 1983

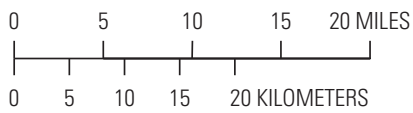

\section{EXPLANATION}

[Arsenic concentration, in milligrams per liter $(\mathrm{mg} / \mathrm{L}$ ) and field identifier (if concentration is greater than $3 \mathrm{mg} / \mathrm{L}$ )]

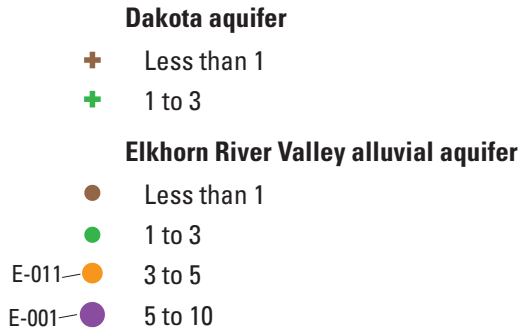

Elkhorn River Valley alluvial aquifer

- Less than 1

- 1 to 3

E-011- 3 to 5

E-001- 5 to 10

Missouri River Valley alluvial aquifer

- Less than 1

- 1 to 3

M-009A-A 3 to 5

M-011- 5 to 10

M-002- Greater than 10

Platte River Valley alluvial aquifer

Less than 1

$\star \quad 1$ to 3

P-006- $\star \quad 3$ to 5

P-010- $\ \quad 5$ to 10

Upland area alluvial aquifers

- Less than 1

- 1 to 3

Wells in well nests

Schematic to illustrate concentration in wells in well nests. Well box is empty if not analyzed for arsenic.

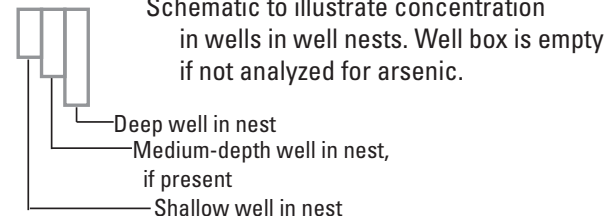

Figure 13. Distribution of arsenic concentrations in the most recent samples in network wells and wells in well nests, PapioMissouri River Natural Resources District, eastern Nebraska, 1992-2009. 

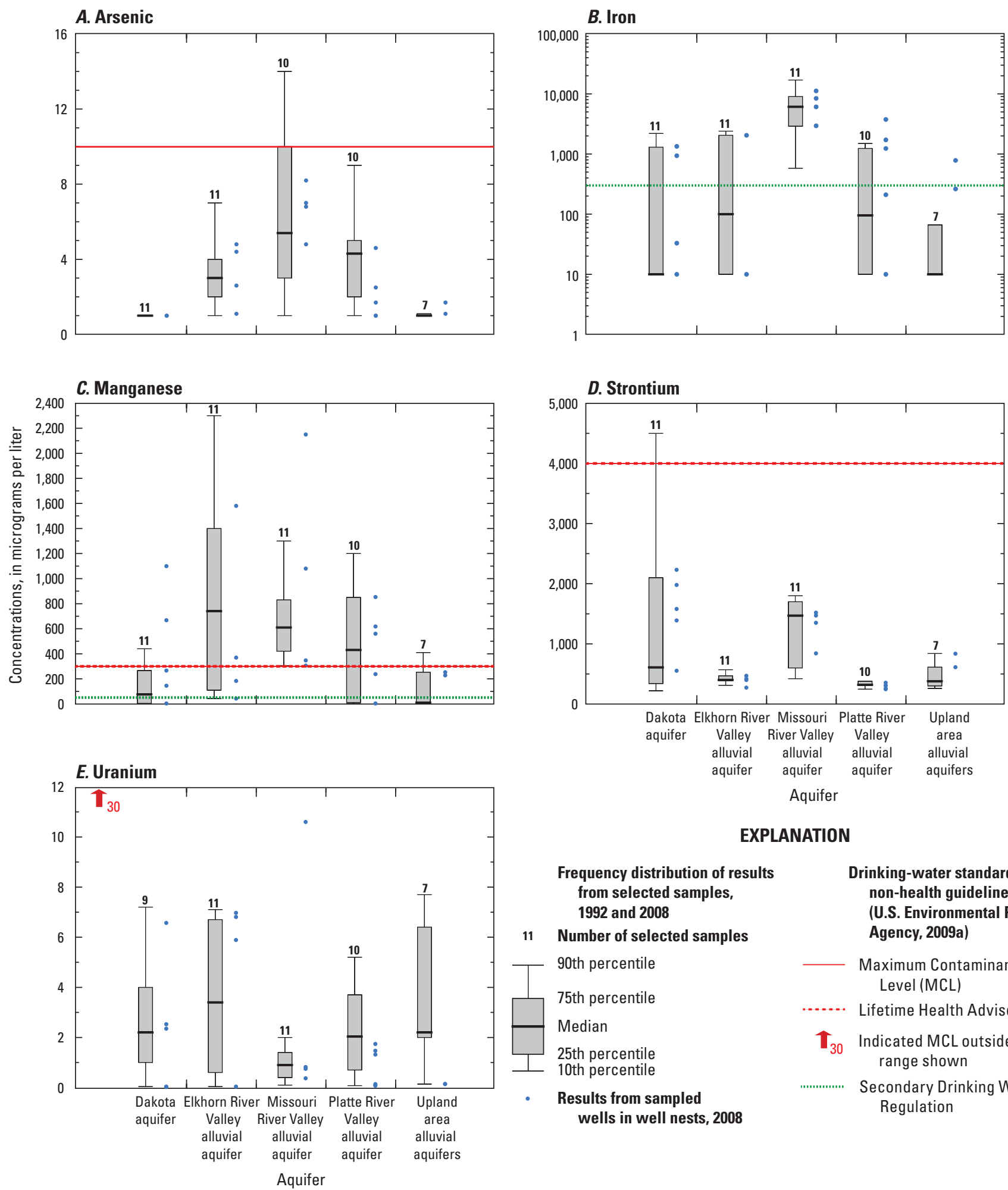

\section{EXPLANATION}

Frequency distribution of results from selected samples, 1992 and 2008

11 Number of selected samples

90th percentile

75th percentile

Median

25th percentile

10th percentile

- Results from sampled wells in well nests, 2008
Drinking-water standards and non-health guidelines (U.S. Environmental Protection Agency, 2009a)

Maximum Contaminant Level (MCL)

Lifetime Health Advisory level

$\boldsymbol{T}_{30}$ Indicated MCL outside of range shown

Secondary Drinking Water Regulation

Figure 14. Concentrations, by aquifer, of $A$, arsenic, $B$, iron, $C$, manganese, $D$, strontium, and $E$, uranium as a frequency distribution using box plots in the most recent samples in network wells in 1992 and in one randomly selected well in each well nest in 2008, and as results using dot plots for all sampled wells in well nests in 2008, Papio-Missouri River Natural Resources District, eastern Nebraska. 
Geologic sources of arsenic to groundwater include arsenic sulfides, iron oxides, and other common minerals containing arsenic. Compounds containing arsenic also have been used as pesticides and wood preservatives, and in glass production. Geochemical conditions and the distribution of arsenic sources in the aquifer affect arsenic concentrations in groundwater. For example, processes that result in elevated arsenic in groundwater include arsenic release from iron oxides, which is favored by high $\mathrm{pH}$ and low dissolved oxygen concentrations. In this study, arsenic concentrations were positively correlated with $\mathrm{pH}$ only in samples from wells in the Platte River Valley alluvial aquifer $(\tan =0.588, p=0.028)$. In general, arsenic concentration did not correlate with dissolved oxygen concentration for this study's samples, but for wells screened in the Missouri River Valley alluvial aquifer, dissolved oxygen concentration was low (less than $0.5 \mathrm{mg} / \mathrm{L}$ ) in 70 percent of the samples that had arsenic concentrations greater than $3.33 \mu \mathrm{g} / \mathrm{L}$. Arsenic concentrations differed over short distances and by more than $2 \mathrm{mg} / \mathrm{L}$ among samples from wells in one well nest (fig. 13), which is consistent with findings in other studies (Focazio and others, 1999; Kelly and others, 2005).

\section{Iron and Manganese}

Iron- and manganese-bearing minerals, which are common constituents of aquifer material, are more soluble in water with low dissolved oxygen concentration (anoxic conditions) and low $\mathrm{pH}$. Both iron and manganese are essential for human health. Manganese may have adverse neurological effects at high doses, but food, rather than drinking water, is the primary source of manganese for people (Agency for Toxic Substances and Disease Registry, 2008). Although neither iron nor manganese have an enforceable USEPA drinking-water standard (MCL), both have a nonenforceable USEPA drinking-water standard (SDWR) $-300 \mu \mathrm{g} / \mathrm{L}$ for iron and $50 \mu \mathrm{g} / \mathrm{L}$ for manganese (U.S. Environmental Protection Agency, 2009a).

Iron was detected in 68 percent of the selected traceelement samples. Iron concentrations were greater than the USEPA SDWR of $300 \mu \mathrm{g} / \mathrm{L}$ in about 46 percent of samples. In general, wells with sample results where iron concentrations are greater than the USEPA SDWR were screened in the Dakota aquifer or the Elkhorn, Missouri, and Platte River Valleys alluvial aquifers, but not the upland area alluvial aquifers (fig. 14).

Manganese was detected in 84 percent of the selected trace-element samples. Manganese concentrations were greater than the USEPA SDWR of $50 \mu \mathrm{g} / \mathrm{L}$ in about 70 percent of the samples; exceedances of the standard were particularly frequent for samples from wells screened in the Elkhorn, Missouri, and Platte River Valleys alluvial aquifers (fig. 14).

Manganese concentrations did not correlate with dissolved oxygen concentration or $\mathrm{pH}$ in the selected samples, but dissolved oxygen concentrations were less than $0.5 \mathrm{mg} / \mathrm{L}$ in 48 percent of the samples with manganese concentrations greater than $300 \mu \mathrm{g} / \mathrm{L}$. Manganese concentrations were positively correlated with iron concentrations in samples from the
Elkhorn ( $\operatorname{tau}=0.6482, p=0.008)$ and Platte River Valleys alluvial aquifers $(\operatorname{tau}=0.562, p=0.038)$, likely because in groundwater, the chemical behaviors of iron and manganese are similar.

\section{Strontium}

Strontium was detected in 100 percent of the selected trace-element samples. Strontium is geochemically similar to calcium and will replace minor amounts of calcium and potassium in igneous rocks. Carbonate and sulfate rocks containing strontium are common parent materials in sediment composing aquifer matrices (Hem, 1985). Strontium concentrations in samples from most ( 80 percent) of the samples ranged from 300 to $1,800 \mu \mathrm{g} / \mathrm{L}$. Concentrations of strontium exceeded the USEPA nonenforceable LTHA of $4,000 \mu \mathrm{g} / \mathrm{L}$ in 4 percent of the samples, all of which were from wells screened in the Dakota aquifer. Strontium may have adverse health effects at high doses, including abnormal bone development (Agency for Toxic Substances and Disease Registry, 2004). Strontium concentrations were greater in samples from wells in the Missouri River Valley alluvial aquifer than those in the Elkhorn River Valley, Platte River Valley, and upland area alluvial aquifers $(p<0.004)$, and strontium concentrations were greater in samples from wells in the Elkhorn River Valley alluvial aquifer than in wells in the Platte River Valley alluvial aquifer $(p=0.013)$.

\section{Uranium}

Uranium was detected in 92 percent of the selected traceelement samples. Health effects of uranium in drinking water include increased risk of cancer and possible harm to kidneys (U.S. Environmental Protection Agency, 2009a). Uranium concentrations did not exceed the USEPA MCL of $30 \mu \mathrm{g} / \mathrm{L}$ in any of the samples in this study. Uranium concentrations in samples from most (80 percent) of the wells ranged from 0.10 to $6.7 \mu \mathrm{g} / \mathrm{L}$; the maximum concentration detected in the selected samples was $7.7 \mu \mathrm{g} / \mathrm{L}$ (fig. 14). Uranium concentrations were not significantly different among the studied aquifers $(p=0.233)$, and uranium concentration was positively correlated with dissolved oxygen concentration ( $\operatorname{tau}=0.294$, $p=0.004)$ in all aquifers. The positive correlation between uranium and dissolved oxygen concentrations is consistent with the greater solubility of the oxidized form of uranium (Hem, 1985) and with findings in other studies (DeSimone, 2009).

\section{Nitrogen and Phosphorus Compounds}

From 1992 to 2009, groundwater samples from the PMRNRD network wells and well nests were analyzed for as many as four nitrogen and phosphorus compounds-ammonia, nitrate, nitrite, and orthophosphate (appendix 3). Nitrogen and phosphorus species in groundwater may originate from 
a variety of natural sources and human activities. Natural sources of nitrogen and phosphorus species in groundwater are precipitation, leaching of soil organic matter, and the rocks and sediment of the aquifer matrix. Human activities that are sources of nitrogen and phosphorus species include fertilizer application, animal production, wastewater disposal, and combustion of fossil fuels (Freeze and Cherry, 1979; Hem, 1985; Nolan and others, 1997; Dubrovsky and others, 2010). Nitrogen in groundwater may be present in the form of ammonia, nitrite, nitrate, or nitrogen gas. Transformations among nitrogen forms in groundwater are controlled by redox conditions and mediated by microorganisms (Freeze and Cherry, 1979; Madigan and others, 2000).

\section{Nitrate}

Nitrate is the most common form of nitrogen in groundwater (Dubrovsky and others, 2010); nitrate is stable and mobile in oxic water. In anoxic water, most nitrate has been converted by microorganisms to other nitrogen forms, such as nitrogen gas or ammonia. Nitrate and nitrite are the only nutrients for which there are USEPA drinking-water standards. Ingestion of water with a large concentration of nitrate can lead to low oxygen levels in the blood of infants (Fan and Steinberg, 1996). The USEPA MCL for nitrate is $10 \mathrm{mg} / \mathrm{L}$ as nitrogen; the USEPA MCL for nitrite is $1 \mathrm{mg} / \mathrm{L}$ as nitrogen (U.S. Environmental Protection Agency, 2009a).

Nitrate was detected in 56 percent of the most recent summer-to-fall samples from network wells and one randomly selected well in each well nest, 1992 to 2009. This set of 200 samples is hereinafter referred to as the nutrient samples, 1992 to 2009. In the Missouri River Valley alluvial aquifer, nitrate was detected in 22 percent of the samples (11 of 49 samples), whereas it was detected in most of the samples from all other aquifers studied (35 of 46 samples, Elkhorn River Valley alluvial aquifer; 19 of 27 samples, Platte River Valley alluvial aquifer; and 26 of 43 samples, upland area alluvial aquifers) (fig. 15A). As illustrated in fig. 15B, nitrate$\mathrm{N}$ concentrations vary by dissolved oxygen range. For nutrient samples, 1992 to 2009 ,

- In 85 (about 42 percent) of the samples with dissolved oxygen concentrations of less than $0.5 \mathrm{mg} / \mathrm{L}$,

- Nitrate-N concentrations were $0.06 \mathrm{mg} / \mathrm{L}$ or less in 62 of these samples and

- Nitrate-N concentrations were greater than $0.06 \mathrm{mg} / \mathrm{L}$ in 23 of these samples.

- In 106 (about 53 percent) of the samples with dissolved oxygen concentrations of $0.5 \mathrm{mg} / \mathrm{L}$ or greater,

- Nitrate-N concentrations were $0.06 \mathrm{mg} / \mathrm{L}$ or less in 26 of these samples and

- Nitrate-N concentrations were greater than $0.06 \mathrm{mg} / \mathrm{L}$ in 80 of these samples.
- In 9 (about 4 percent) of the samples, where dissolved oxygen concentration was not measured,

- Nitrate-N concentrations were $0.06 \mathrm{mg} / \mathrm{L}$ or less in 3 of these samples and

- Nitrate-N concentrations were greater than $0.06 \mathrm{mg} / \mathrm{L}$ in 6 of these samples.

In nutrient samples, 1992 to 2009, with dissolved oxygen concentrations greater than $0.5 \mathrm{mg} / \mathrm{L}$ (oxic water), there was a positive correlation between nitrate- $\mathrm{N}$ and dissolved oxygen concentrations $(\operatorname{tau}=0.22, p=0.002)$.

The concentration distribution of nitrate-N from 1992 to 2009 was significantly lower in the Missouri River Valley alluvial aquifer than in the other four studied aquifers ( $p$-values $<0.01$; fig. $15 A$ ). There was no statistically significant difference in nitrate-N concentrations among the Dakota, Elkhorn River Valley alluvial, Platte River Valley alluvial, and upland area alluvial aquifers ( $p$-values from 0.35 to 0.98 ).

Nitrate-N concentrations in the nutrient samples, 1992 to 2009 , for most ( 80 percent) wells ranged from less than 0.06 to $8.55 \mathrm{mg} / \mathrm{L}$, with a median value of $0.12 \mathrm{mg} / \mathrm{L}$ (table 10 ). Concentrations of nitrate- $\mathrm{N}$ in 13 (7 percent) nutrient samples, 1992 to 2009, were greater than or equal to the USEPA MCL of $10 \mathrm{mg} / \mathrm{L}$, and concentrations of nitrate- $\mathrm{N}$ in 35 (18 percent) of the nutrient samples, 1992 to 2009, were greater than or equal to $5 \mathrm{mg} / \mathrm{L}$, which is the PMRNRD action level for possible management implementation to reduce nitrate concentration in groundwater. The PMRNRD action level is 50 percent of the Nebraska Title-118 standard for the associated analyte (Papio-Missouri Natural Resources District, 1994).

Concentrations of nitrate-N were greater than $1 \mathrm{mg} / \mathrm{L}$ in 72 (36 percent) nutrient samples, 1992 to 2009; in many parts of the United States, a concentration greater than $1 \mathrm{mg} / \mathrm{L}$ is considered to result from the effects of human activities (Nolan and Hitt, 2006). However, if the concentration of nitrate- $\mathrm{N}$ is less than $1 \mathrm{mg} / \mathrm{L}$ and the water is anoxic, it cannot be presumed that the water was not affected by human activities because it is likely the nitrate input from natural and man-made sources was consumed by microorganisms through denitrification.

The spatial distribution of denitrification in the PMRNRD groundwater was assessed using (1) the concentration of dissolved oxygen (measured on site prior to sampling, 1992 to 2009), (2) the concentration of dissolved nitrogen gas and methane (measured in 2000 and 2004), and (3) $\delta^{15} \mathrm{~N}_{\mathrm{AIR}}$ in nitrate and dissolved nitrogen gas (measured in 2004). Under anoxic conditions, microorganisms will reduce nitrate to nitrogen gas if nitrate and a suitable electron donor are present (McMahon and others, 2009). In the nutrient samples, 1992 to 2009 , the water was anoxic in 85 (44 percent) of the 191 samples with dissolved oxygen results (fig. 15B). Evidence of denitrification can be obtained from dissolved gases and $\delta^{15} \mathrm{~N}_{\text {AIR }}$ results. The amount of excess nitrogen gas can be derived from the dissolved-gases results for nitrogen and argon and the estimated recharge temperature and recharge 
A. Nitrate plus nitrite by aquifer, 1992-2009

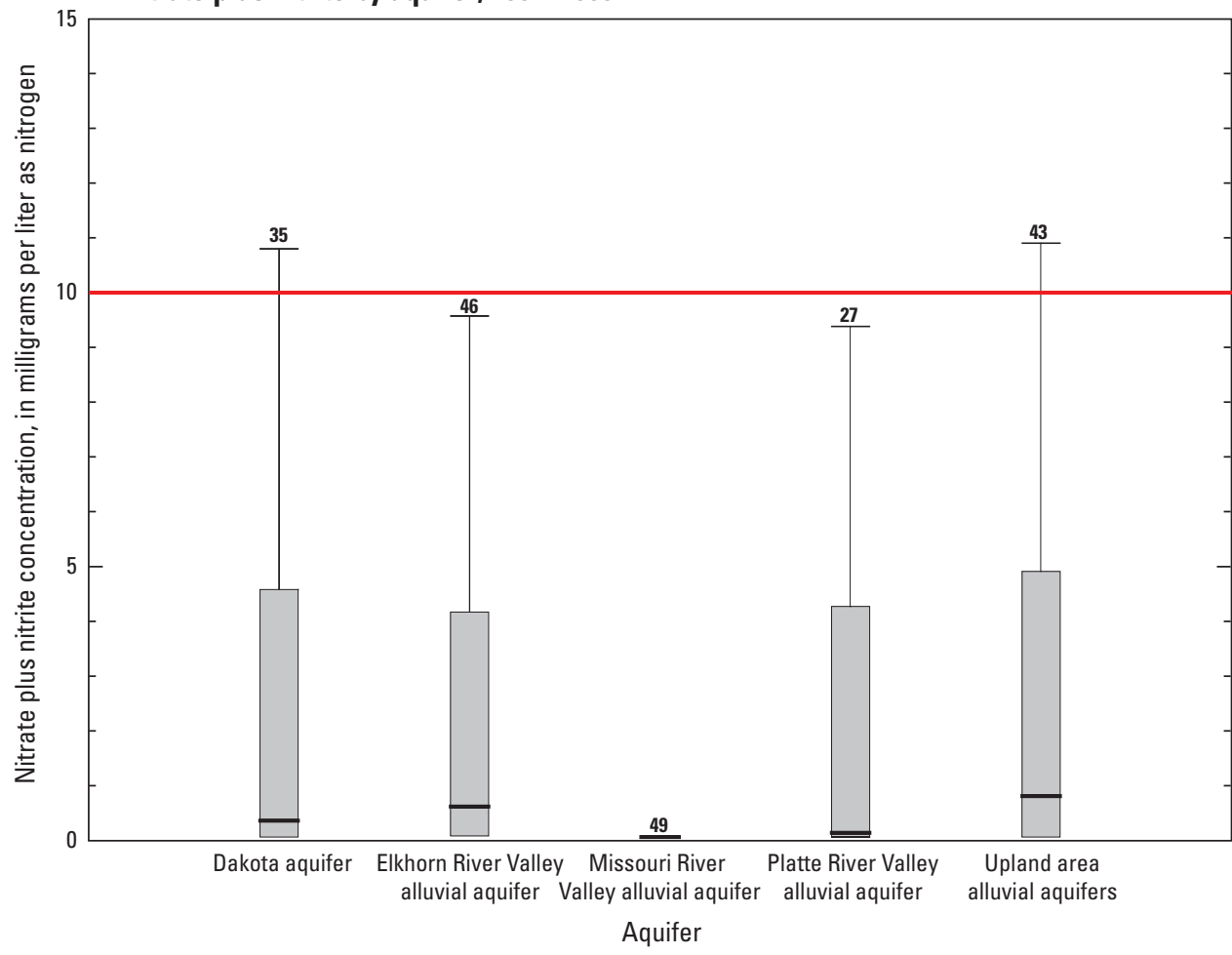

B. Nitrate plus nitrite by dissolved oxygen range, 1992-2009

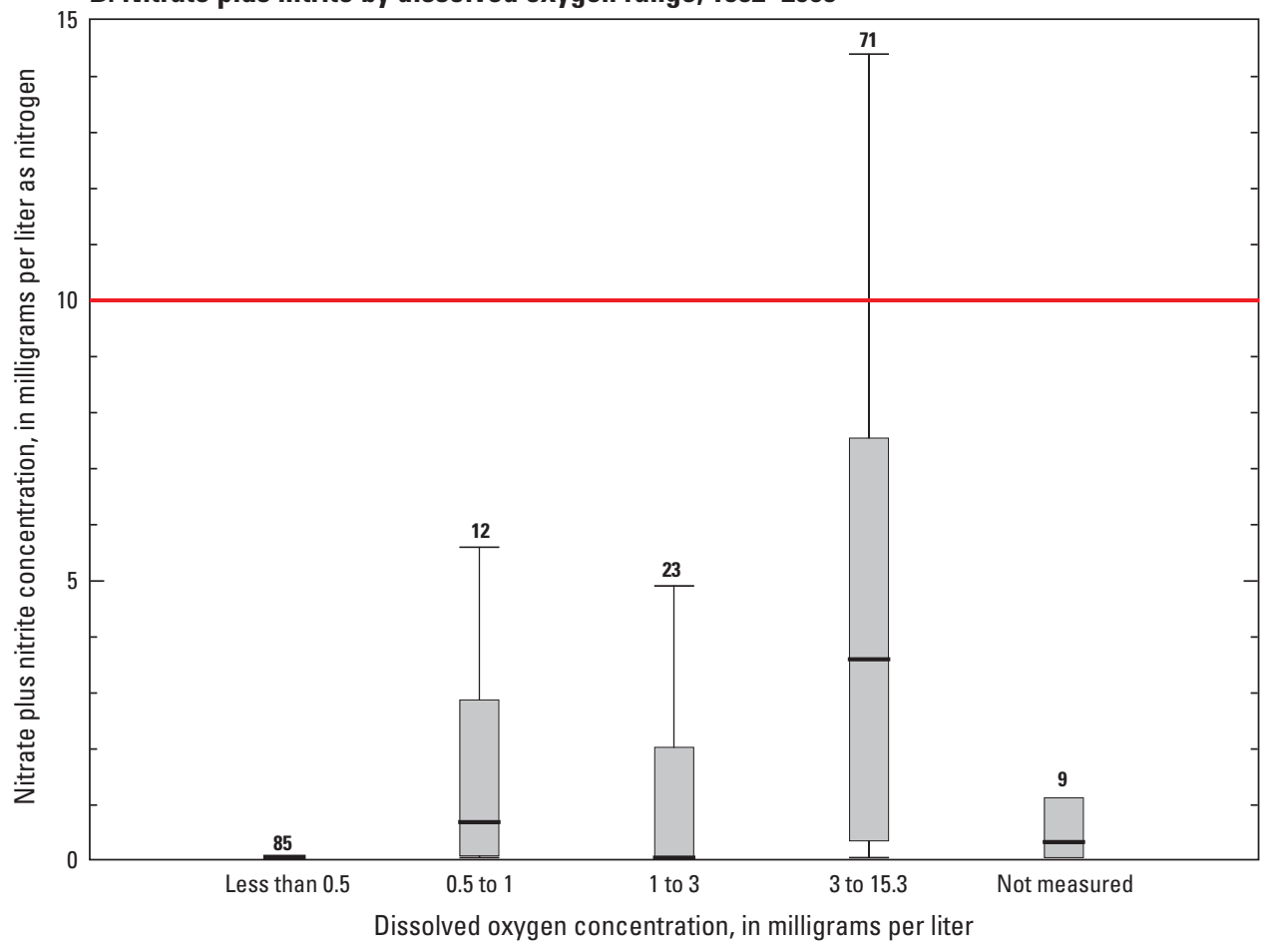

Figure 15. Frequency distribution of nitrate plus nitrite concentration $A$, by aquifer and $B$, by dissolved oxygen range in the most recent summer-to-fall samples in network wells and in one randomly selected well in each well nest, Papio-Missouri River Natural Resources District, eastern Nebraska, 1992-2009.

\section{EXPLANATION}

Frequency distribution of results from selected samples, 1992-2009

27

Number of samples

90th percentile

75th percentile

Median

25th percentile

10th percentile

Drinking-water standards (U.S. Environmental Protection Agency, 2009a)

Maximum Contaminant Level 
elevation (Kendall and Aravena, 2000). The concentrations of dissolved gases in samples collected from wells in the well nests in 2000 indicate that excess nitrogen gas was present in three-fourths of the sampled wells. The excess nitrogen gas concentrations ranged from 18 to 460 micromoles per liter $(\mu \mathrm{M} / \mathrm{L})$ (table 12$)$. In 2000 , excess nitrogen gas was not detected in the samples from two wells (P-A1 and P-A2) in the well nest near Ashland, Nebr. (Ashland, Nebr., which is not shown in fig. 1, is located about $11 \mathrm{mi}$ southwest of Gretna, Nebr.); however, methane gas was detected in these samples. The excess nitrogen gas or presence of methane gas indicate that at least some denitrification likely was occurring in groundwater within the capture area for wells with dissolved gas analysis (table 12).

The $\delta^{15} \mathrm{~N}_{\mathrm{AIR}}$ ratios in nitrate were measured in 2004 in the well nests near Venice and Springfield to possibly indicate (1) the source of nitrate in groundwater and (2) evidence of denitrification (Kendall and McDonnell, 1998). The $\delta^{15} \mathrm{~N}_{\text {AIR }}$ ratios in nitrate were estimated as 26 per mil (\%) and $26.6 \%$ in wells E-V3 and E-V1, respectively, which combined with low nitrate-N $(30-181 \mu \mathrm{M})$ and low dissolved oxygen $(20-30 \mu \mathrm{M})$ concentrations in these wells, indicates that substantial denitrification had occurred. The dissolved gas and stable isotope results from 2004 for wells P-S1, P-S2, and P-S3 are potentially misinformative because inadequate pumping of the wells likely affected the results. The $\delta^{15} \mathrm{~N}_{\mathrm{AIR}}$ ratios in nitrate result for P-S1, P-S2, and P-S3 were $9.36 \%$, $8.32 \%$, and $8.44 \%$, respectively. These $\delta^{15} \mathrm{~N}_{\text {AIR }}$ in nitrate results indicate that the source of the nitrate likely is commercial inorganic fertilizer. For commercial fertilizer, the range of $\delta^{15} \mathrm{~N}_{\text {AIR }}$ in nitrate is -8\%o to $7 \%$; for nitrate from organic fertilizer, plant residue, and animal or human waste, the range of $\delta^{15} \mathrm{~N}_{\mathrm{AIR}}$ in nitrate is $2 \%$ to $30 \%$ (Kendall and McDonald, 1998). In well P-S2, concentrations of nitrate-N $(254 \mu \mathrm{M})$ and methane $(49 \mu \mathrm{M})$ indicate there is a mixture of water sources in this well; some water in which substantial denitrification has occurred and other water with elevated nitrate likely are still present.

The estimated fractional decrease in the amount of nitrate, $f$ from equation 3 , is greater than 0.5 in all sampled wells in well nests (table 12) except wells D-T3, E-V1, P-A2, P-A1, P-S2, and P-S1. The samples from wells P-A2 and P-A1 were slightly oxic in 2000 (dissolved oxygen concentration equal to 0.8 and $0.7 \mathrm{mg} / \mathrm{L}$, respectively; table 7), and large iron and manganese concentrations were present in samples from these wells collected about 5 months after the collection of samples for dissolved gases in 2000 (table 12). Large iron and manganese results indicate reducing conditions existed somewhere along the groundwater flow path. Redox classification results (table 9) indicate that, from 1999 to 2009 , samples from wells P-A2 and P-A1 have been both anoxic and mixed oxic-anoxic. The lack of excess nitrogen gas in wells P-A2 and P-A1 (table 12) likely means the $\mathrm{N}_{2}$ has degassed from the water at the sampled depths. Estimated $f$ was 0.1 or less for wells D-T3, P-S2, and P-S1; these results (evidence of little denitrification) agree with the oxic redox classification (table 9) of these wells from samples from 1999 to 2009 .

To determine whether the concentration distribution of nitrate-N by aquifer had changed from the 1992 to 1994 sampling period to the 2007 to 2009 sampling period, the most recent summer-to-fall samples were selected for each network well sampled during the two sampling periods and for one randomly selected well in each well nest sampled in the 2007 to 2009 sampling period. These two sets of samples are hereinafter referred to as the nutrient samples, 1992 to 1994 (88 samples), and nutrient samples, 2007 to 2009 (93 samples). For nitrate-N concentration, there was no significant difference among the nutrient samples, 1992 to 1994, and the nutrient samples, 2007 to 2009 (figs. $16 A$ and 16B), for any of the five studied aquifers ( $p$-values range from 0.13 to 0.84 ). In addition, there was no significant difference for any studied aquifer in the nitrate-N concentrations (1) between the 1992 to 1994 and 1992 to 2009 periods ( $p$-values from 0.334 to 0.980 ) or (2) between the 2007 to 2009 and 1992 to 2009 periods ( $p$-values from 0.274 to 0.956 ).

The most recent summer-to-fall nitrate- $\mathrm{N}$ concentration for each of 109 sampled wells in the 2007 to 2009 sampling period, including results for all wells in well nests, is mapped in figure 17. In the nutrient samples, 2007 to 2009, there are six wells (D-009A, D-034, D-T3, E-022, P-107, and U-011) with nitrate-N concentrations greater than the USEPA MCL. In the nutrient samples, 2007 to 2009, nine wells (D-005D, D-006, D-011, E-022E, M-204, P-S1, P-102, P-S2, and U-011A) had nitrate-N concentrations less than the USEPA MCL but greater than $5 \mathrm{mg} / \mathrm{L}$ ( 50 percent of the USEPA MCL for nitrate-N), which is the PMRNRD action level for possible management implementation to decrease nitrate concentrations in groundwater (Papio-Missouri Natural Resources District, 1994).

The wells in well nests were sampled for nitrate from 19 to 60 times during 1999 to 2009 (appendix 8). The final summer-to-fall sample in each year was selected for each well in the well nests to assess whether nitrate-N concentrations were changing over time. The only such wells with a statistically significant $(p<0.05)$ trend in nitrate concentrations are in the nest near Venice (wells E-V1, E-V2; fig. 18), the nest near Springfield (wells P-S1, P-S2, and P-S3; fig. 18), and the nest near Walthill, Nebr. (well D-W2). One well in the nest in Tekamah (well D-T3) did not have a significant trend in nitrate- $\mathrm{N}$ concentrations ( $\operatorname{tau}=0.45$, $p=0.09)$, but nitrate- $\mathrm{N}$ concentrations have been consistently very high (greater than $20 \mathrm{mg} / \mathrm{L}$ ) in this well (fig. 18). Temporal trends in nitrate- $\mathrm{N}$ concentrations were negative for wells in well nests near Venice and Walthill-E-V1 $($ tau $=-0.60, p=0.02)$, E-V2 (tau $=-0.64, p=0.01)$, and $\mathrm{D}-\mathrm{W} 2(\operatorname{tau}=-0.53$ and $p=0.04)$. The trends in nitrate concentrations were positive for wells in the well nest near Springfield-P-S1 (tau $=0.78, p=0.002), \mathrm{P}-\mathrm{S} 2(\operatorname{tau}=0.73$, $p=0.004)$, and $\mathrm{P}-\mathrm{S} 3(\operatorname{tau}=0.60$ and $p=0.02)$. 
Table 12. Estimated recharge temperature, excess nitrogen gas, initial nitrate concentration, and fraction of initial nitrate in recharge that has been removed by denitrification using dissolved gases and related data, Papio-Missouri River Natural Resources District, eastern Nebraska, 2000 and 2004.

[ft, feet; NGVD 29, National Geodetic Vertical Datum of 1929; $\mu \mathrm{M}$, micromoles per liter; $\mathrm{N}_{2}$, nitrogen gas; $\mathrm{N}$, nitrogen; \%o, AIR, nitrogen isotope ratio in per mil of the atmospheric air standard; ${ }^{\circ} \mathrm{C}$, degrees Celsius; $\mathrm{cm}^{3} \mathrm{STP} / \mathrm{L}$, cubic centimeters per liter at standard temperature and pressure; $\mathrm{NO}_{\text {, }}$, nitrate; $\mathrm{mg} / \mathrm{L}$, milligrams per liter; O, oxygen; \%, VSMOW, oxygen isotope ratio in per mil of the Vienna Standard Mean Ocean Water; $f$, fraction of initial nitrate in recharge removed by denitrification; <, less than; --, no data; E; estimated]

\begin{tabular}{|c|c|c|c|c|c|c|c|c|c|c|c|c|}
\hline $\begin{array}{c}\text { Field } \\
\text { identifier } \\
\text { (fig. 8) }\end{array}$ & $\begin{array}{l}\text { Dissolved } \\
\text { gases } \\
\text { sample } \\
\text { date }\end{array}$ & $\begin{array}{l}\text { Estimated } \\
\text { elevation of water } \\
\text { table in recharge } \\
\text { area (ft above } \\
\text { NGVD 29) }\end{array}$ & $\begin{array}{l}\text { Depth to } \\
\text { water, ft } \\
\text { below land } \\
\text { surface }\end{array}$ & $\begin{array}{c}\text { Depth of middle } \\
\text { of screen, below } \\
\text { water table, } \\
\text { ft }\end{array}$ & $\begin{array}{l}\text { Oxygen, } \\
\text { field } \\
(\mu \mathrm{M})\end{array}$ & $\begin{array}{c}\text { Methane } \\
(\mu \mathrm{M})\end{array}$ & $\begin{array}{l}\text { Nitrogen gas } \\
\left(\mathrm{N}_{2}\right) \\
(\mu \mathrm{M})\end{array}$ & $\begin{array}{c}\delta^{15} \mathbf{N} \\
\left(\mathbf{N}_{2}\right) \\
(\% 0, \mathrm{AIR})\end{array}$ & $\begin{array}{c}\text { Argon } \\
(\mu \mathrm{M})\end{array}$ & $\begin{array}{c}\text { Estimated } \\
\text { recharge } \\
\text { tempature } \\
\left({ }^{\circ} \mathrm{C}\right)\end{array}$ & $\begin{array}{l}\text { Excess air } \\
\left(\mathrm{cm}^{3} \text { STP/L) }\right.\end{array}$ & $\begin{array}{l}\text { Estimated } \\
\text { excess } \\
\text { nitrogen gas } \\
\left(\mathrm{N}_{2}\right)(\mu \mathrm{M})\end{array}$ \\
\hline \multicolumn{13}{|c|}{ Dakota aquifer } \\
\hline D-T3 & $6 / 14 / 00$ & 1,135 & 38.27 & 36.7 & 260 & $<1$ & 745 & -- & 17.81 & 9 & 2.0 & 36 \\
\hline D-T1 & $6 / 14 / 00$ & 1,135 & 44.80 & 123.7 & 3 & $<1$ & 815 & -- & 18.70 & 6 & 1.3 & 89 \\
\hline D-W3 & $6 / 13 / 00$ & 1,212 & 16.73 & 82.8 & 3 & $<1$ & 786 & -- & 18.38 & 7 & 1.3 & 71 \\
\hline \multicolumn{13}{|c|}{ Elkhorn River Valley alluvial aquifer } \\
\hline E-EC2 & $6 / 15 / 00$ & 1,136 & 6.32 & 13.7 & 10 & $<1$ & 1,000 & -- & 15.83 & 14 & 2.1 & 360 \\
\hline $\mathrm{E}-\mathrm{V} 3$ & $6 / 15 / 00$ & 1,107 & 7.38 & 9.6 & 20 & $<1$ & 1,020 & -- & 14.20 & 18 & 0.5 & 460 \\
\hline E-V3 & $10 / 18 / 04$ & 1,107 & 5.91 & 11.1 & 30 & $<1$ & 711 & E1.9 & 13.63 & 20 & 0.4 & 180 \\
\hline E-V2 & $10 / 18 / 04$ & 1,107 & 6.15 & 49.4 & 20 & $<1$ & 628 & .97 & 15.72 & 13 & 0.7 & 18 \\
\hline E-V1 & $6 / 15 / 00$ & 1,107 & 8.03 & 87.5 & 3 & $<1$ & 766 & -- & 16.84 & 10 & 1.2 & 110 \\
\hline E-V1 & $10 / 18 / 04$ & 1,107 & 6.06 & 89.4 & 20 & $<1$ & 656 & .92 & 16.50 & 11 & 0.8 & 18 \\
\hline \multicolumn{13}{|c|}{ Missouri River Valley alluvial aquifer } \\
\hline $\mathrm{M}-\mathrm{BC} 3$ & $6 / 15 / 00$ & 995 & 11.52 & 6.0 & 30 & $<1$ & 824 & -- & 18.04 & 8 & 2.0 & 110 \\
\hline M-H3 & $6 / 13 / 00$ & 1,092 & 22.99 & 25.0 & 69 & $<1$ & 799 & -- & 17.42 & 11 & 2.7 & 89 \\
\hline M-H1 & $6 / 13 / 00$ & 1,092 & 23.94 & 102.6 & 3 & $<1$ & 865 & -- & 19.40 & 5 & 1.7 & 110 \\
\hline \multicolumn{13}{|c|}{ Platte River Valley alluvial aquifer } \\
\hline P-A3 & $6 / 12 / 00$ & 1,055 & 6.19 & 9.8 & 20 & 1 & 730 & -- & 16.36 & 12 & 1.1 & 89 \\
\hline P-A2 & $6 / 12 / 00$ & 1,055 & 6.02 & 29.0 & 10 & 2 & 599 & -- & 15.48 & 14 & 0.6 & 0 \\
\hline P-A1 & $5 / 31 / 00$ & 1,055 & 5.58 & 46.9 & 10 & 2 & 608 & -- & 15.96 & 12 & 0.2 & 0 \\
\hline P-S3 & $6 / 12 / 00$ & 1,020 & 16.68 & 33.3 & 97 & $<1$ & 808 & -- & 15.73 & 14 & 1.6 & 180 \\
\hline P-S3 & $10 / 18 / 04$ & 1,020 & 16.03 & 34.0 & 120 & $<1$ & 698 & E2.1 & 16.00 & 13 & 1.0 & 71 \\
\hline P-S2 & $10 / 18 / 04$ & 1,020 & 16.38 & 51.1 & 200 & 49 & 560 & E1.0 & 14.63 & 16 & 0.1 & 0 \\
\hline P-S1 & $6 / 12 / 00$ & 1,020 & 17.03 & 63.5 & 190 & $<1$ & 670 & -- & 16.47 & 12 & 1.5 & 18 \\
\hline P-S1 & $10 / 18 / 04$ & 1,020 & 16.48 & 64.0 & 230 & $<1$ & 604 & -- & 15.66 & 13 & 0.5 & 0 \\
\hline \multicolumn{13}{|c|}{ Upland area alluvial aquifers } \\
\hline U-BA1 & $6 / 13 / 00$ & 1,210 & 160.11 & 62.4 & 130 & $<1$ & 732 & -- & 17.78 & 8 & 1.4 & 36 \\
\hline
\end{tabular}


Table 12. Estimated recharge temperature, excess nitrogen gas, initial nitrate concentration, and fraction of initial nitrate in recharge that has been removed by denitrification using dissolved gases and related data, Papio-Missouri River Natural Resources District, eastern Nebraska, 2000 and 2004.—Continued

[ft, feet; NGVD 29, National Geodetic Vertical Datum of 1929; $\mu \mathrm{M}$, micromoles per liter; $\mathrm{N}_{2}$, nitrogen gas; $\mathrm{N}$, nitrogen; \%, AIR, nitrogen isotope ratio in per mil of the atmospheric air standard; ${ }^{\circ} \mathrm{C}$, degrees Celsius; $\mathrm{cm}^{3} \mathrm{STP} / \mathrm{L}$, cubic centimeters per liter at standard temperature and pressure; $\mathrm{NO}_{3}$, nitrate; $\mathrm{mg} / \mathrm{L}$, milligrams per liter; O, oxygen; \%o, VSMOW, oxygen isotope ratio in per mil of the Vienna Standard Mean Ocean Water; $f$, fraction of initial nitrate in recharge removed by denitrification; <, less than; --, no data; E; estimated]

\begin{tabular}{|c|c|c|c|c|c|c|c|c|c|c|c|c|}
\hline $\begin{array}{c}\text { Field } \\
\text { identifier } \\
\text { (fig. 8) }\end{array}$ & $\begin{array}{l}\text { Nitrate } \\
\text { sample } \\
\text { date }\end{array}$ & $\begin{array}{c}\text { Nitrate }\left(\mathrm{NO}_{3}\right) \\
\text { measured } \\
(\mathrm{mg} / \mathrm{L} \text { as } \mathrm{N})\end{array}$ & $\begin{array}{c}\text { Nitrate }\left(\mathrm{NO}_{3}\right) \\
\text { measured } \\
(\mu \mathrm{M})\end{array}$ & $\begin{array}{c}\delta^{15} \mathrm{~N} \\
\left(\mathrm{NO}_{3}\right) \\
(\%, \mathrm{AIR})\end{array}$ & $\begin{array}{c}\delta^{18} \mathrm{O} \\
\left(\mathrm{NO}_{3}\right) \\
(\%, \text { VSMOW) }\end{array}$ & $\begin{array}{c}\text { Estimated nitrate } \\
\left(\mathrm{NO}_{3}\right) \text { initial } \\
(\mu \mathrm{M})\end{array}$ & $\begin{array}{c}\text { Estimated nitrate } \\
\left(\mathrm{NO}_{3}\right) \text { initial } \\
(\mathrm{mg} / \mathrm{L} \text { as } \mathrm{N})\end{array}$ & $\begin{array}{c}\text { Estimated } \\
\qquad f\end{array}$ & $\begin{array}{c}\text { Iron, man- } \\
\text { ganese, and } \\
\text { sulfate sample } \\
\text { date } \\
\end{array}$ & $\begin{array}{l}\text { Iron } \\
\text { (mg/L) }\end{array}$ & $\begin{array}{l}\text { Manganese } \\
(\mathrm{mg} / \mathrm{L})\end{array}$ & $\begin{array}{r}\text { Sulfate } \\
\text { (mg/L) }\end{array}$ \\
\hline \multicolumn{13}{|c|}{ Dakota aquifer } \\
\hline D-T3 & $5 / 17 / 00$ & 16.7 & 1,190 & -- & -- & 1,260 & 18 & 0.1 & $10 / 31 / 00$ & $<10$ & 3.2 & 34.4 \\
\hline D-T1 & $5 / 17 / 00$ & 1.88 & 134 & -- & -- & 313 & 4 & .6 & $10 / 31 / 00$ & $<10$ & 488 & 239 \\
\hline D-W3 & $5 / 17 / 00$ & $<.06$ & $<4$ & -- & -- & 100 & 2 & 1 & $10 / 31 / 00$ & 993 & 439 & 86.1 \\
\hline \multicolumn{13}{|c|}{ Elkhorn River Valley alluvial aquifer } \\
\hline E-EC2 & $5 / 18 / 00$ & $<0.06$ & $<4$ & -- & -- & 700 & 10 & 1 & $10 / 30 / 00$ & 2,160 & 1,640 & 68.4 \\
\hline $\mathrm{E}-\mathrm{V} 3$ & $5 / 16 / 00$ & 7.36 & 526 & -- & -- & 1,450 & 20 & 0.6 & $10 / 30 / 00$ & $<10$ & 503 & 72.7 \\
\hline E-V3 & $10 / 18 / 04$ & 2.54 & 181 & E26 & E16 & 538 & 8 & .7 & $10 / 18 / 04$ & $<10$ & 308 & 58.2 \\
\hline E-V2 & $10 / 18 / 04$ & $<.06$ & $<4$ & -- & -- & 40 & .6 & .9 & $10 / 18 / 04$ & 82 & 195 & 88.7 \\
\hline E-V1 & $5 / 16 / 00$ & 1.56 & 111 & -- & -- & 326 & 5 & .7 & $10 / 30 / 00$ & 30 & 42.4 & 72.6 \\
\hline E-V1 & $10 / 18 / 04$ & .42 & 30 & 26.6 & 17.5 & 66 & 1 & .5 & $10 / 18 / 04$ & 15 & 41.5 & 85.1 \\
\hline \multicolumn{13}{|c|}{ Missouri River Valley alluvial aquifer } \\
\hline M-BC3 & $5 / 18 / 00$ & $<0.06$ & $<4$ & -- & -- & 200 & 3 & 1 & $11 / 1 / 00$ & 1,090 & 1,440 & 71.4 \\
\hline M-H3 & $5 / 17 / 00$ & $<.06$ & $<4$ & -- & -- & 200 & 3 & 1 & $10 / 31 / 00$ & 8,150 & 1,040 & 72.6 \\
\hline M-H1 & $5 / 17 / 00$ & $<.06$ & $<4$ & -- & -- & 200 & 3 & 1 & $10 / 31 / 00$ & 5,640 & 352 & 247 \\
\hline \multicolumn{13}{|c|}{ Platte River Valley alluvial aquifer } \\
\hline P-A3 & $5 / 16 / 00$ & $<0.06$ & $<4$ & -- & -- & 200 & 3 & 1 & $10 / 30 / 00$ & 3,250 & 819 & 35.0 \\
\hline P-A2 & $5 / 16 / 00$ & $<.06$ & $<4$ & -- & -- & 4 & .05 & 0 & $10 / 30 / 00$ & 1,620 & 750 & 22.9 \\
\hline P-A1 & $5 / 16 / 00$ & $<.06$ & $<4$ & -- & -- & 4 & .05 & 0 & $10 / 30 / 00$ & 1,190 & 683 & 20.9 \\
\hline P-S3 & $5 / 16 / 00$ & 2.07 & 148 & -- & -- & 505 & 7 & .7 & $10 / 30 / 00$ & 226 & 228 & 25.3 \\
\hline $\mathrm{P}-\mathrm{S} 3$ & $10 / 18 / 04$ & 3.54 & 253 & 8.44 & 4.03 & 396 & 6 & .4 & $10 / 18 / 04$ & 204 & 238 & 26.3 \\
\hline P-S2 & $10 / 18 / 04$ & 3.56 & 254 & 8.32 & 3.74 & 254 & 4 & 0 & $10 / 18 / 04$ & 30 & 3.4 & 15.7 \\
\hline P-S1 & $5 / 16 / 00$ & 4.67 & 333 & -- & -- & 369 & 5 & .1 & $10 / 30 / 00$ & $<10$ & 2.0 & 17.9 \\
\hline P-S1 & $10 / 18 / 04$ & 7.11 & 508 & 9.36 & 3.50 & 508 & 7 & 0 & $10 / 18 / 04$ & $<10$ & $<0.6$ & 20.7 \\
\hline \multicolumn{13}{|c|}{ Upland area alluvial aquifers } \\
\hline U-BA1 & $5 / 18 / 00$ & $<0.05$ & $<4$ & -- & -- & 80 & 1 & 1 & $11 / 1 / 00$ & 592 & 230 & 34.4 \\
\hline
\end{tabular}


A. Nitrate plus nitrite by aquifer, 1992-1994

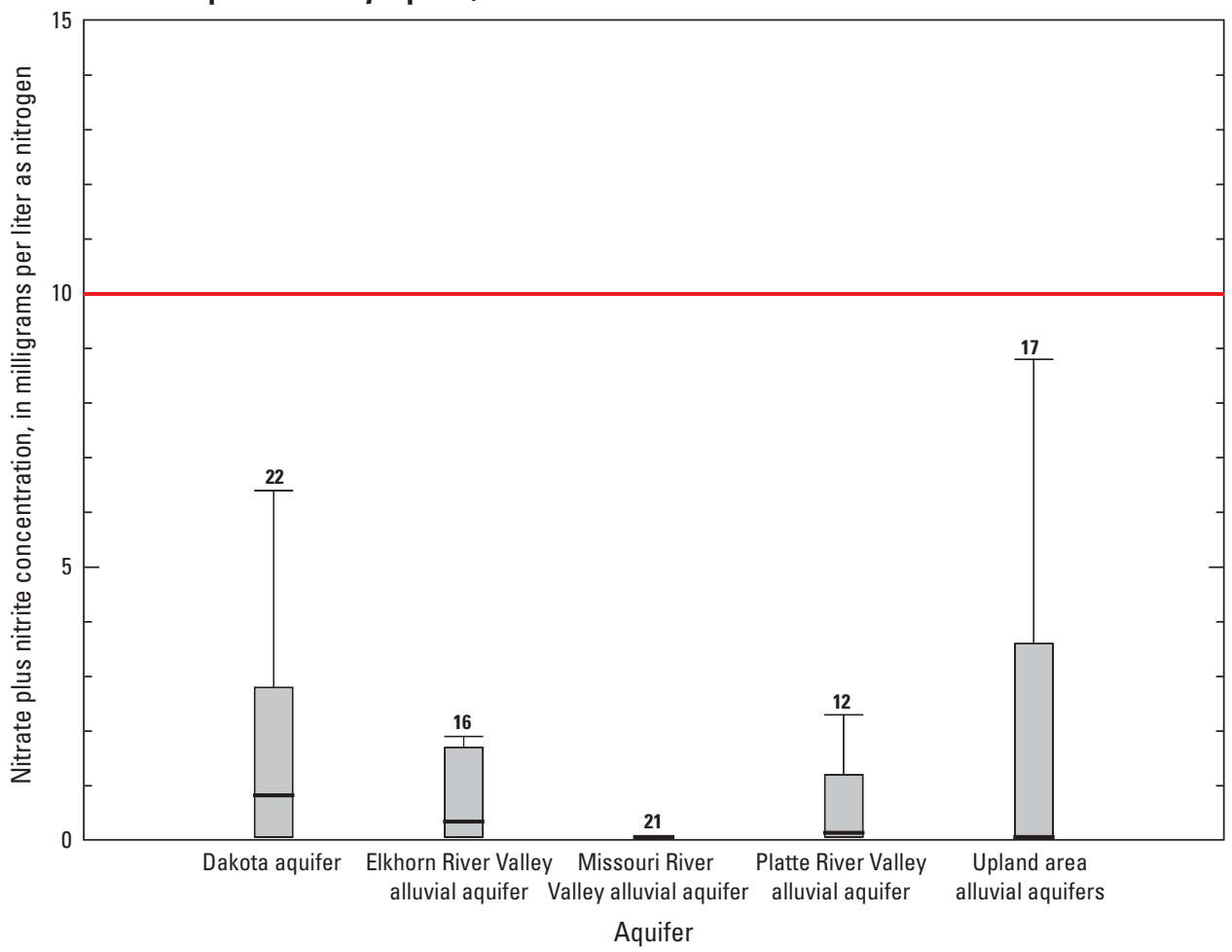

B. Nitrate plus nitrite by aquifer, 2007-2009

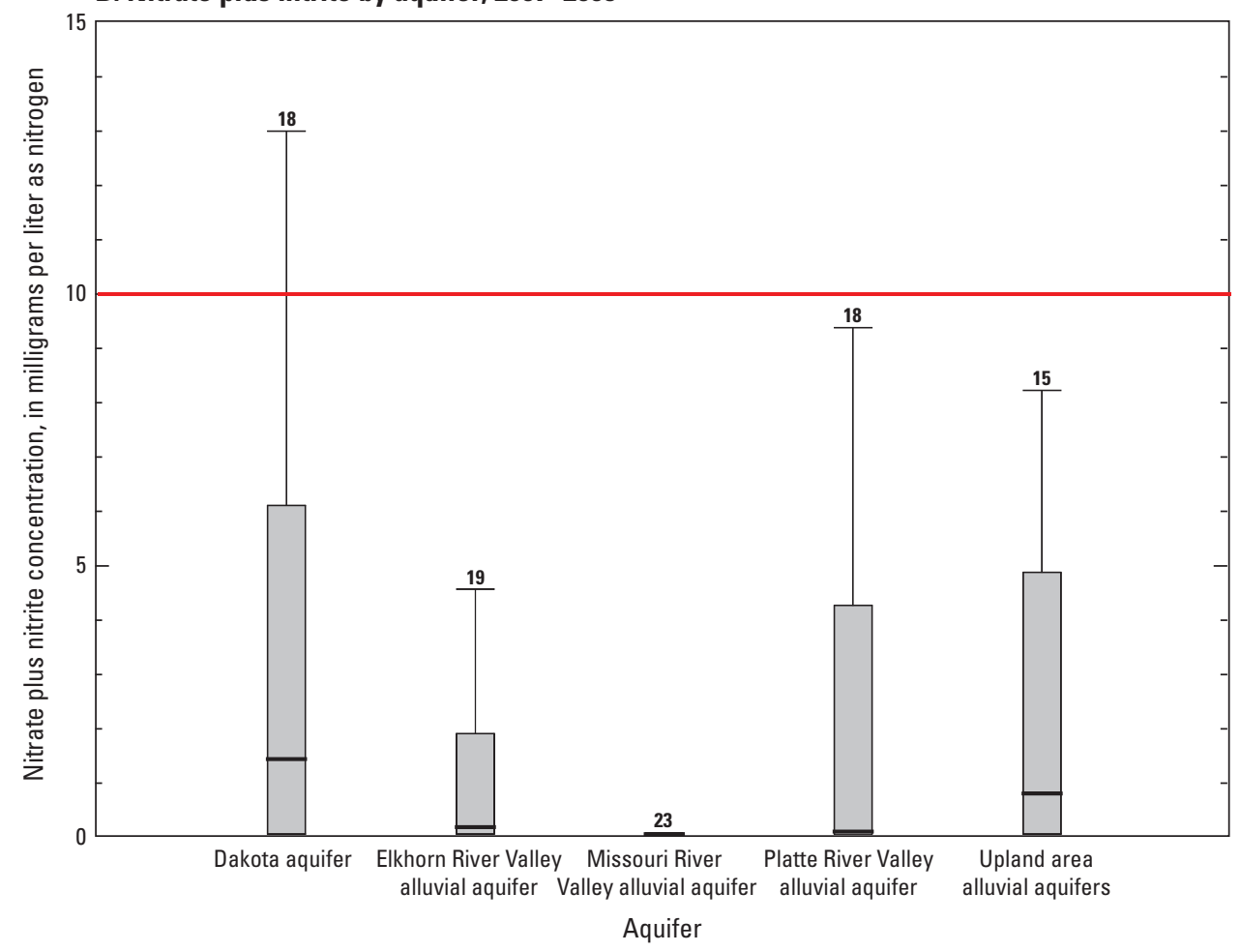

Figure 16. Frequency distribution of nitrate plus nitrite concentration, by aquifer, in the most recent summer-to-fall samples $A$, in network wells, 1992-1994, and $B$, in network wells and one randomly selected well in each well nest, 2007-2009, Papio-Missouri River Natural Resources District, eastern Nebraska.

\section{EXPLANATION}

Frequency distribution of results from selected samples, for the period indicated

18 Number of samples

90th percentile

75th percentile

Median

25th percentile

10th percentile

Drinking-water standards (U.S. Environmental Protection Agency, 2009a)

Maximum Contaminant Level 


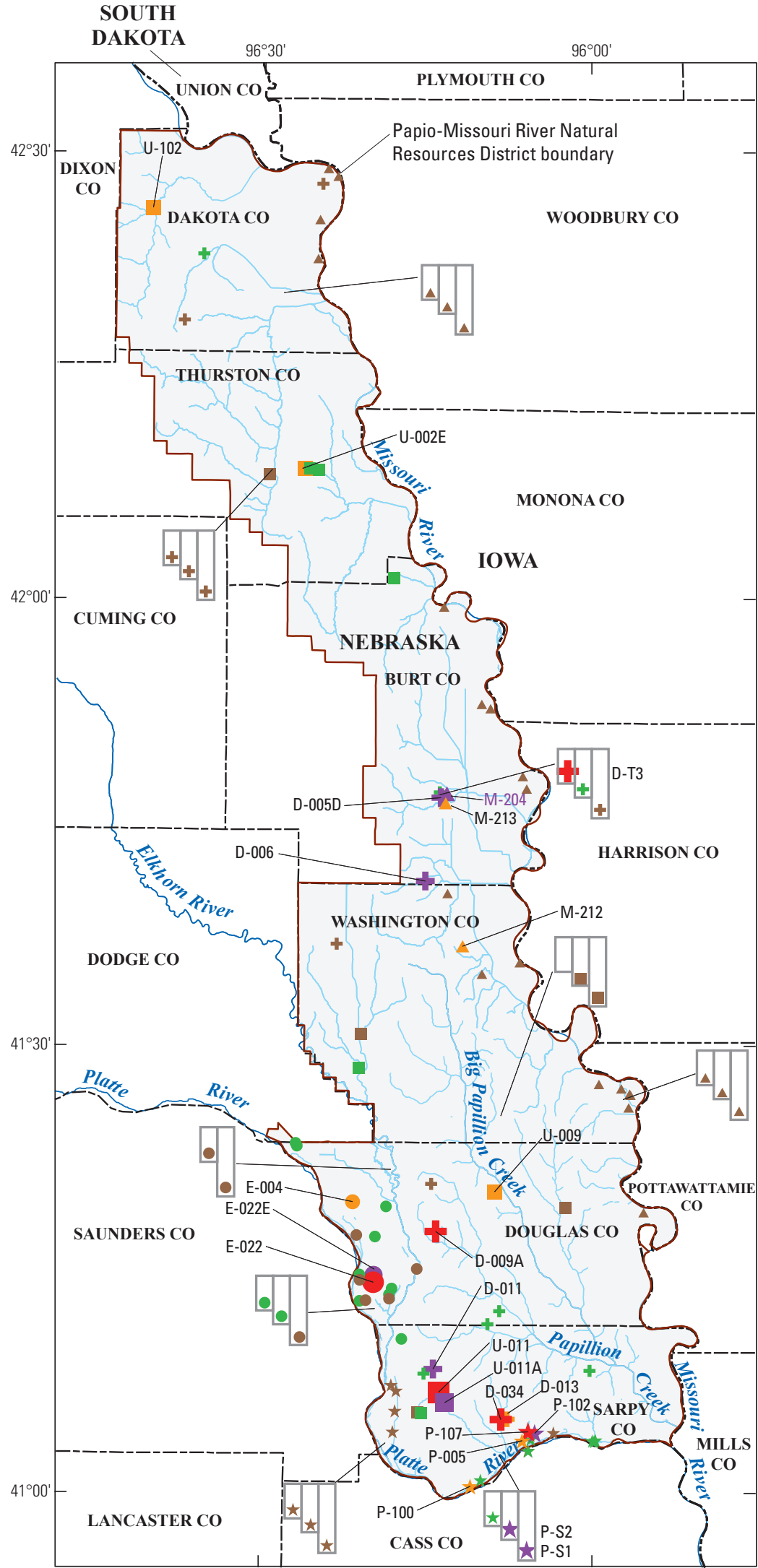

Base from U.S. Geological Survey digital data, 2001, 1:2,000,000 Albers Equal-Area Conic projection

Standard parallels $29^{\circ} 30^{\prime} \mathrm{N}$ and $45^{\circ} 40^{\prime} \mathrm{N}$

Central meridian $97^{\circ} 30^{\prime} \mathrm{W}$

North American Datum of 1983

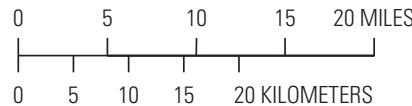

\section{EXPLANATION}

[Nitrate plus nitrite concentration, in milligrams per liter (mg/L) as nitrogen, and field identifier (if concentration is greater than $3.3 \mathrm{mg} / \mathrm{L}$ )]

\section{Dakota aquifer}

$+\quad$ Less than 0.06

$+\quad 0.06$ to 3.3

D-013-4 3.3 to 5.0

D-006- 5.0 to 10

D-T3- 10 or greater

Elkhorn River Valley alluvial aquifer

- Less than 0.06

- $\quad 0.06$ to 3.3

E-004- $\quad 3.3$ to 5.0

E-022E- 5.0 to 10

E-022-

10 or greater

Missouri River Valley alluvial aquifer

- Less than 0.06

M-212-A $\quad 0.06$ to 3.3

M-204-A 3.3 to 5.0

Platte River Valley alluvial aquifer

$\star \quad$ Less than 0.06

$\star \quad 0.06$ to 3.3

P-005- $\star \quad 3.3$ to 5.0

P-102- $\quad 5.0$ to 10

P-107- $\star \quad 10$ or greater

Upland area alluvial aquifers

- Less than 0.06

- $\quad 0.06$ to 3.3

U-009- 3.3 to 5.0

$\mathrm{U}-011 \mathrm{~A}-\quad 5.0$ to 10

U-011- 10 or greater

\section{Wells in well nests}

Schematic to illustrate concentration in wells in well nests. Well box is empty if not analyzed for nitrate plus nitrite as nitrogen

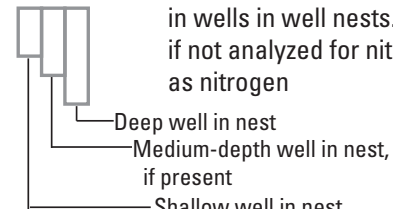

Shallow well in nest

Figure 17. Distribution of the most recent summer-to-fall nitrate plus nitrite concentration for each sampled well, Papio-Missouri River Natural Resources District, eastern Nebraska, 2007-2009. 
A. Wells in the D-T well nest, Tekamah, Nebraska, screened in the Dakota aquifer

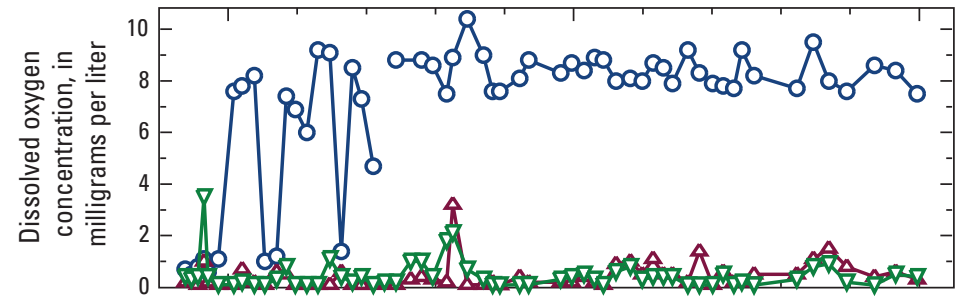

EXPLANATION

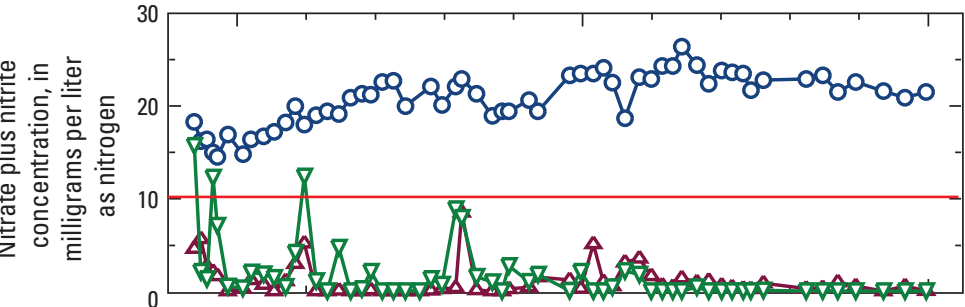

Well identifier

$\longrightarrow$ D-T3

$\triangle \mathrm{D}-\mathrm{T} 2$

$\longrightarrow \mathrm{D}-\mathrm{T} 1$

Drinking-water standard

(U.S . Environmental

Protection Agency, 2009a)

Maximum Contaminant Level

B. Wells in the E-V well nest, near Venice, Nebraska, screened in the Elkhorn River Valley alluvial aquifer

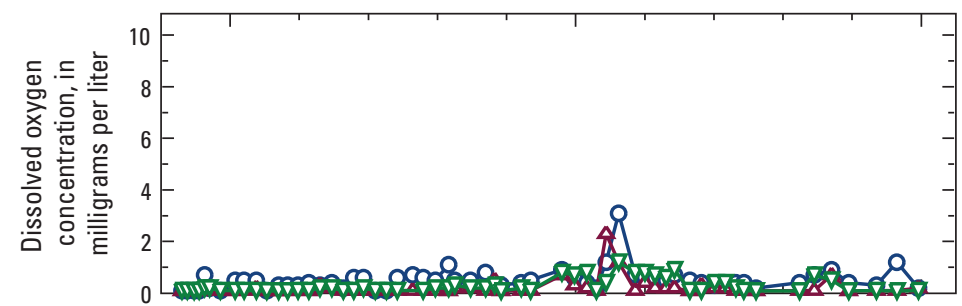

EXPLANATION

Well identifier

$\longrightarrow$ E-V3

$\triangle \quad \mathrm{E}-\mathrm{V} 2$

$\longrightarrow \mathrm{E}-\mathrm{V} 1$

Drinking-water standard

(U.S . Environmental

Protection Agency, 2009a)

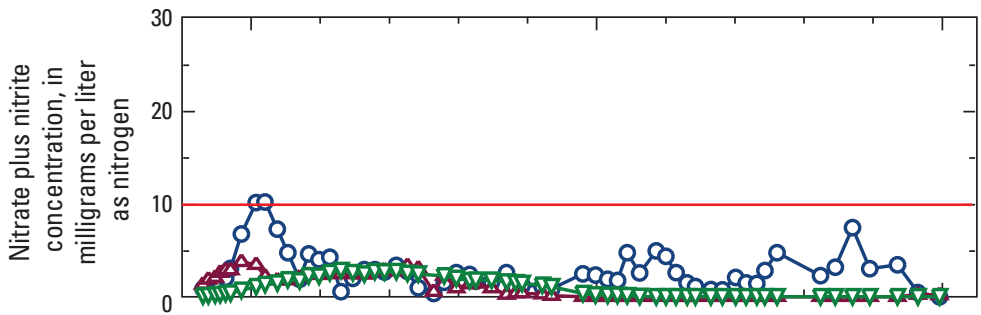

Maximum Contaminant Level

C. Wells in the P-S well nest, near Springfield, Nebraska, screened in the Platte River Valley alluvial aquifer

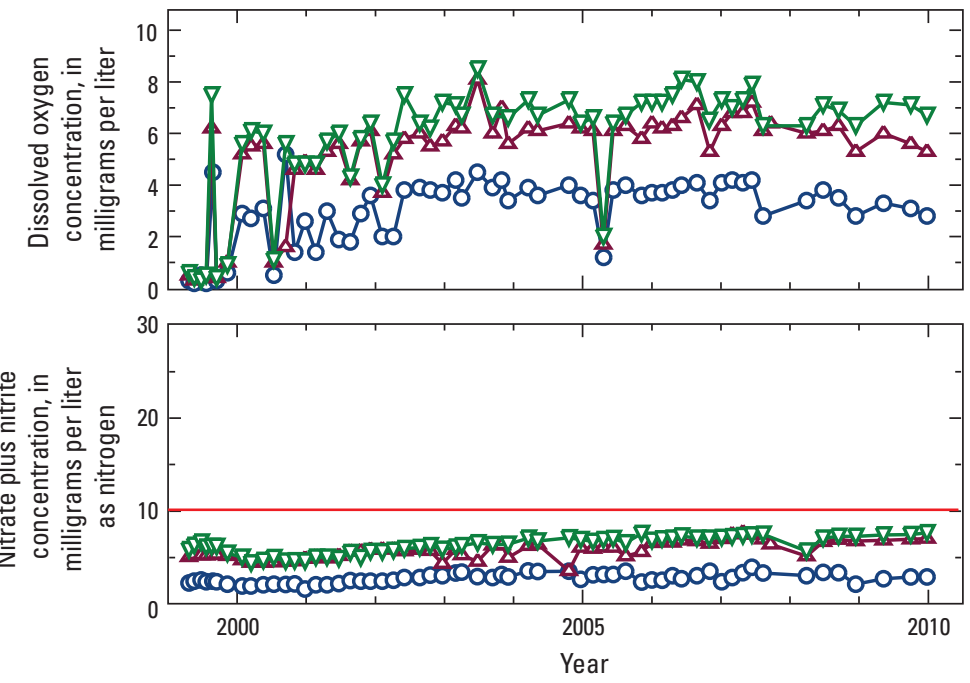

EXPLANATION

Well identifier

$\longrightarrow$ P-S3

$\triangle \quad P-S 2$

$\longrightarrow$ P-S1

Drinking-water standard (U.S . Environmental Protection Agency, 2009a)

Maximum Contaminant Leve

Figure 18. Concentrations of dissolved oxygen and nitrate plus nitrite in samples collected from wells in the $A$, well nest in Tekamah, Nebraska, $B$, well nest near Venice, Nebraska, and $C$, well nest near Springfield, Nebraska, Papio-Missouri River Natural Resources District, eastern Nebraska, 1999-2009. 


\section{Nitrite, Ammonia, Orthophosphate Results}

From 1992 through 1998, only one sample from the PMRNRD wells was analyzed for nitrite, ammonia, and orthophosphate concentrations. From 1999 to 2009, 1,218 samples collected from selected PMRNRD wells were analyzed for nitrite, ammonia, and orthophosphate concentrations. In this report, the most recent such analysis in the nutrient samples, 1992 to 2009, are termed the other-nutrients samples, 1992 to 2009. The concentrations of nitrite as nitrogen (nitrite-N) in 99 of the 113 other-nutrients samples, 1992 to 2009, were at or less than $0.008 \mathrm{mg} / \mathrm{L}$, the maximum LRL (table 10). The largest nitrite-N concentration was $0.088 \mathrm{mg} / \mathrm{L}$ in a sample from the Elkhorn River Valley alluvial aquifer (E-022D), which is less than the USEPA MCL for nitrite-N $(1 \mathrm{mg} / \mathrm{L})$. For the other-nutrients samples, 1992 to 2009 , nitrite-N was detected in 2 of the samples from the Dakota aquifer, 8 of the samples from the Elkhorn River Valley alluvial aquifer, none of the samples from the Missouri River Valley alluvial aquifer, 4 of the samples from the Platte River Valley alluvial aquifer, and none of the samples from the upland area alluvial aquifers.

Ammonia is a reduced nitrogen species that typically will oxidize to nitrate when dissolved oxygen is present. Ammonia was detected in 57 of the 113 other-nutrients samples, 1992 to 2009. In 46 of the samples with detectable ammonia, neither nitrate nor nitrite was detected. Ammonia was detected most often in samples from the Missouri River Valley alluvial aquifer ( 21 of 23 samples or 91 percent), followed by the upland area alluvial aquifers (10 of 22 samples, or 45 percent), Dakota aquifer (8 of 19 samples or 42 percent), Platte River Valley alluvial aquifer ( 8 of 21 samples or 38 percent), and Elkhorn River Valley alluvial aquifer (10 of 28 samples or 36 percent). Concentrations of ammonia ranged from less than 0.04 to $1.81 \mathrm{mg} / \mathrm{L}$ as $\mathrm{N}$; none of the samples had ammonia concentrations that exceeded the USEPA nonenforceable standard of $30 \mathrm{mg} / \mathrm{L}$ as N. Ammonia concentrations were negatively correlated with dissolved oxygen concentrations $(\operatorname{tau}=-0.24, p=0.01)$.

Concentrations of orthophosphate as phosphorus $(\mathrm{P})$ ranged from less than 0.02 to $0.89 \mathrm{mg} / \mathrm{L}$ as $\mathrm{P}$; orthophosphate concentration was less than $0.25 \mathrm{mg} / \mathrm{L}$ as $\mathrm{P}$ in nearly 90 percent of the other-nutrients samples, 1992 to 2009 (table 10). Orthophosphate is the most common form of phosphorus in groundwater; because orthophosphate tends to precipitate or sorb onto aquifer materials, its mobility in soils and groundwater generally is limited (Tesoriero and others, 2009).

\section{Pesticides and Pesticide Degradates}

Pesticides, which include herbicides, insecticides, and fungicides, are used to control competing vegetation, insects, and fungi in agricultural, urban, and suburban settings.

Groundwater samples from the PMRNRD network wells and wells in well nests were analyzed for a total of 71 pesticides or pesticide degradates from 1992 to 2009 and 61 pesticides or pesticide degradates from 2007 to 2009 (appendix 4). Of
61 pesticides or pesticide degradates analyzed from 2007 to 2009, 21 were detected (fig. 19). Three of the 21 pesticides detected (alachlor, atrazine, and metolachlor) have established health-based drinking-water standards; all detected concentrations of these compounds were below their USEPA standards.

From 2007 to 2009, one or more pesticide compounds were detected in samples from 16 of 82 network wells and in samples from 18 of 26 wells in well nests (fig. 20). The number of detections from 2007 to 2009, including those detected using the ELISA screening kits for triazine and metolachlor, summarized by aquifer, are Platte River Valley alluvial aquifer, 41 detections; Elkhorn River Valley alluvial aquifer, 33 detections; Dakota aquifer, 14 detections; Missouri River Valley alluvial aquifer, 2 detections; and upland area alluvial aquifers, 2 detections. From 2007 to 2009, the individual pesticide compounds that were detected most frequently were alachlor ethane sulfonic acid (ESA), a degradate of alachlor (8 percent); deethylcyanazine acid (DCAC), a degradate of cyanazine (7 percent); and atrazine (7 percent). Alachlor, atrazine, and cyanazine are among the most commonly detected pesticide compounds in groundwater nationally (Gilliom and others, 2006). However, sale of cyanazine ceased after 2002 because of a voluntary cancellation of the product registration (U.S. Environmental Protection Agency, 2000).

\section{Explosives and Volatile Organic Compounds}

Some samples collected from groundwater underlying the former NOP, which is located about 6 mi west of Gretna, Nebr., and west of the PMRNRD boundary, in Saunders County, Nebr., contained measureable concentrations of explosives, primarily RDX, and VOCs, primarily trichloroethylene (TCE). The explosive and VOC contaminants were associated with U.S. Department of Defense activities at the former NOP during and since World War II. The U.S. Army Corps of Engineers is responsible for groundwater remediation at the NOP site (U.S. Army Corps of Engineers, 2010).

Samples from wells E-V1, E-V2, and E-V3, which are wells in a well nest near Venice, Nebr., and about 8 mi northeast of the NOP site, were analyzed for explosives and VOCs in 2008 and 2009 (appendixes 5 and 6). No explosives or VOCs were detected in either the 2008 or 2009 samples.

\section{Radon}

Radon is a naturally occurring radioactive gas found in soils, rock, and water. Radon has a number of different isotopes. The most prevalent radon isotope in groundwater is ${ }^{222}$ radon. ${ }^{222}$ Radon is produced by the decay of ${ }^{226}$ radium, part of the ${ }^{238}$ uranium decay series, and has a half-life of 3.8 days; ${ }^{222}$ radon decays to lead by alpha particle emission (Hem, 1985). ${ }^{222}$ Radon concentration in groundwater can be affected by multiple factors, including the distribution of uranium-bearing minerals in the aquifer material, aquifer physical characteristics, 
Figure 19. The most recent concentration of pesticide compounds that were detected at levels greater than the maximum laboratory reporting level, in each sampled well, Papio-Missouri River Natural Resources District, eastern Nebraska, 2007-2009.

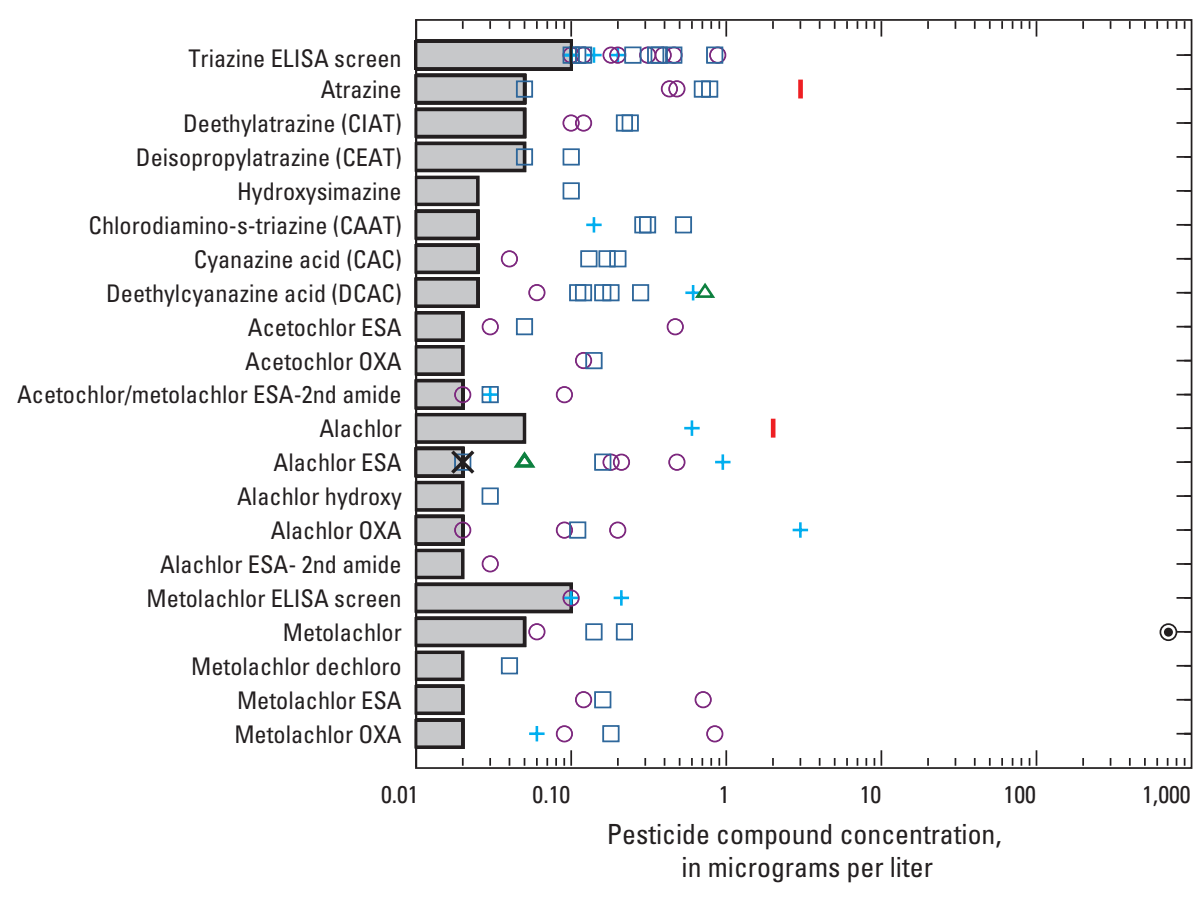

EXPLANATION

\begin{tabular}{cc} 
Most recent pesticide compound concentration \\
$+\quad$ & Dakota aquifer (14 detections) \\
\hline & Elkhorn River Valley alluvial aquifer (33 detections) \\
$\Delta$ & Missouri River Valley alluvial aquifer (2 detections) \\
$\square$ & Platte River Valley alluvial aquifer (41 detections) \\
$\times$ & Upland area alluvial aquifers (2 detections) \\
\hline & Maximum laboratory reporting level, 2007 to 2009 \\
& Drinking-water standard (U.S. Environmental \\
I & Protection Agency, 2009a) \\
$\odot \quad$ Maximum Contaminant Level \\
Lifetime Health Advisory level
\end{tabular}

standards for ${ }^{222}$ radon $-4,000 \mathrm{pCi} / \mathrm{L}$ and $300 \mathrm{pCi} / \mathrm{L}$. The $4,000 \mathrm{pCi} / \mathrm{L}$ standard is an alternative USEPA MCL, which is proposed for public water systems for states or water-system service areas with programs to reduce radon risks from all sources. The $300 \mathrm{pCi} / \mathrm{L}$ standard is proposed as the USEPA MCL for states or water-service areas without such plans (U.S. Environmental Protection Agency, 2009a).

For this study, ${ }^{222}$ radon activity was detected in 39 network wells in 1992 and 19 wells in well nests in 2008 (fig. 21; appendix 8). ${ }^{222}$ Radon activity in the most recent samples collected from network wells and in one randomly selected well in each well nest ranged from less than 80 to $1,200 \mathrm{pCi} / \mathrm{L}$. The median ${ }^{222}$ radon activity in the selected wells was $325 \mathrm{pCi} / \mathrm{L}$, which exceeds the lower proposed USEPA MCL of $300 \mathrm{pCi} / \mathrm{L}$ (table 13). The median ${ }^{222}$ radon activity for the selected wells was greatest in the upland area alluvial aquifers $(430 \mathrm{pCi} / \mathrm{L})$, and the highest radon activity values were in samples from the upland area alluvial aquifers (table 13). 


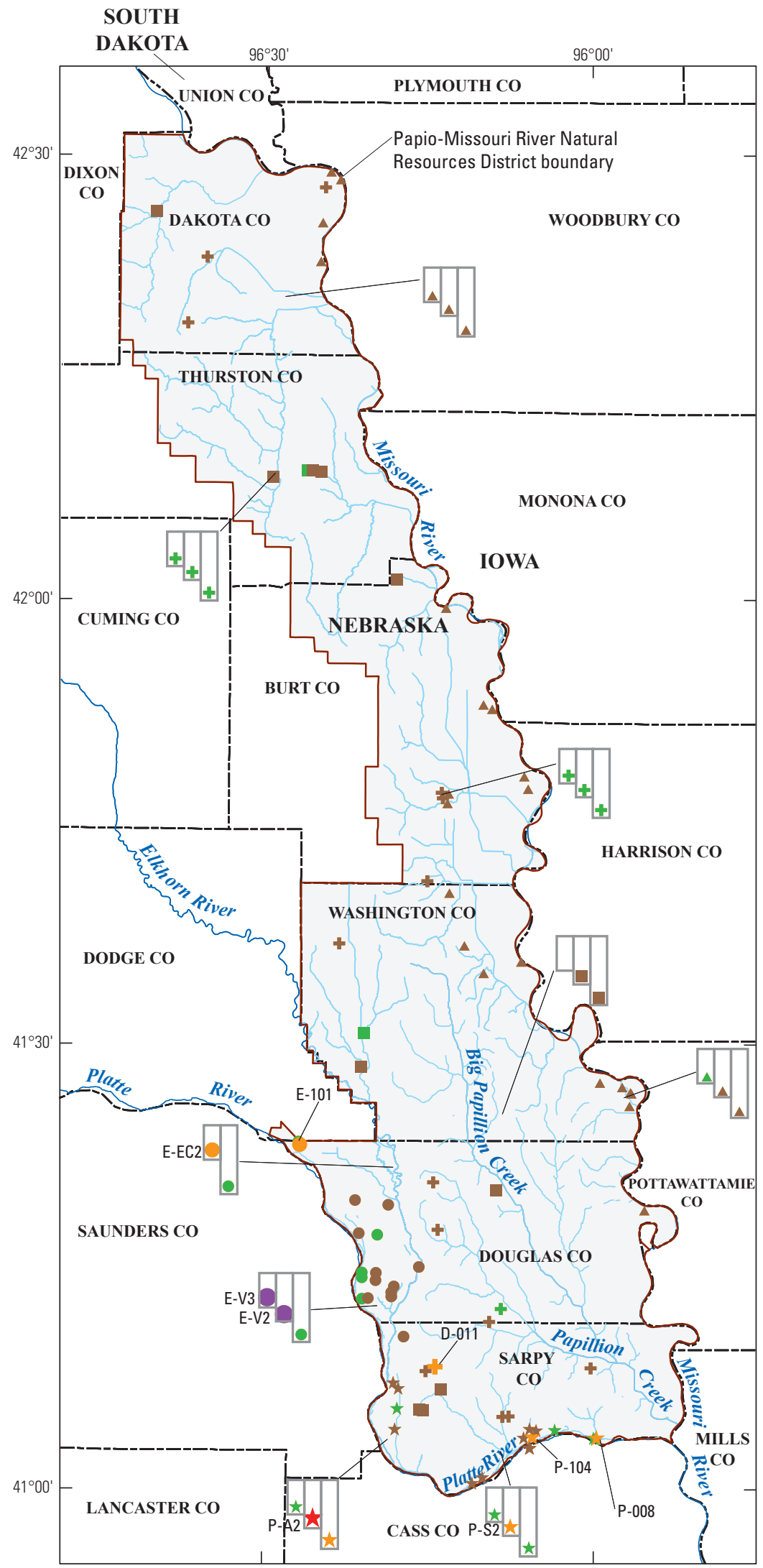

Base from U.S. Geological Survey digital data, 2001, 1:2,000,000

Albers Equal-Area Conic projection

Standard parallels $29^{\circ} 30^{\prime} \mathrm{N}$ and $45^{\circ} 40^{\prime} \mathrm{N}$

Central meridian $97^{\circ} 30^{\prime} \mathrm{W}$

North American Datum of 1983

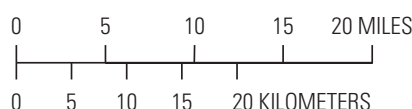

\section{EXPLANATION}

[Number of pesticide compounds detected at concentrations greater than the maximum laboratory

reporting level, 2007-2009, and field identifier (if four or more pesticides detected)]

\section{Dakota aquifer}

$+\quad$ Pesticides not detected

+ 1 to 3 pesticides detected

D-011-4 4 to 6 pesticides detected

Elkhorn River Valley alluvial aquifer

- Pesticides not detected

- 1 to 3 pesticides detected

E-101- 4 to 6 pesticides detected

E-V3- 7 to 9 pesticides detected Missouri River Valley alluvial aquifer

- Pesticides not detected

- 1 to 3 pesticides detected Platte River Valley alluvial aquifer

$\star \quad$ Pesticides not detected

$\star \quad 1$ to 3 pesticides detected

P-008- $\star \quad 4$ to 6 pesticides detected

$\star \quad 7$ to 9 pesticides detected

P-A2 $\star \quad 10$ or more pesticides detected

Upland area alluvial aquifers

Pesticides not detected

- 1 to 3 pesticides detected Wells in well nests

$\begin{gathered}\text { Schematic to illustrate concentration in wells } \\ \text { in well nests. Well box is empty if not } \\ \text { analyzed for pesticide compounds }\end{gathered}$
Deep well in nest
if present
Shallow well in nest

Figure 20. Distribution of number of pesticide compounds detected, by well and by aquifer, in sampled wells, Papio-Missouri River Natural Resources District, eastern Nebraska, 2007-2009. 


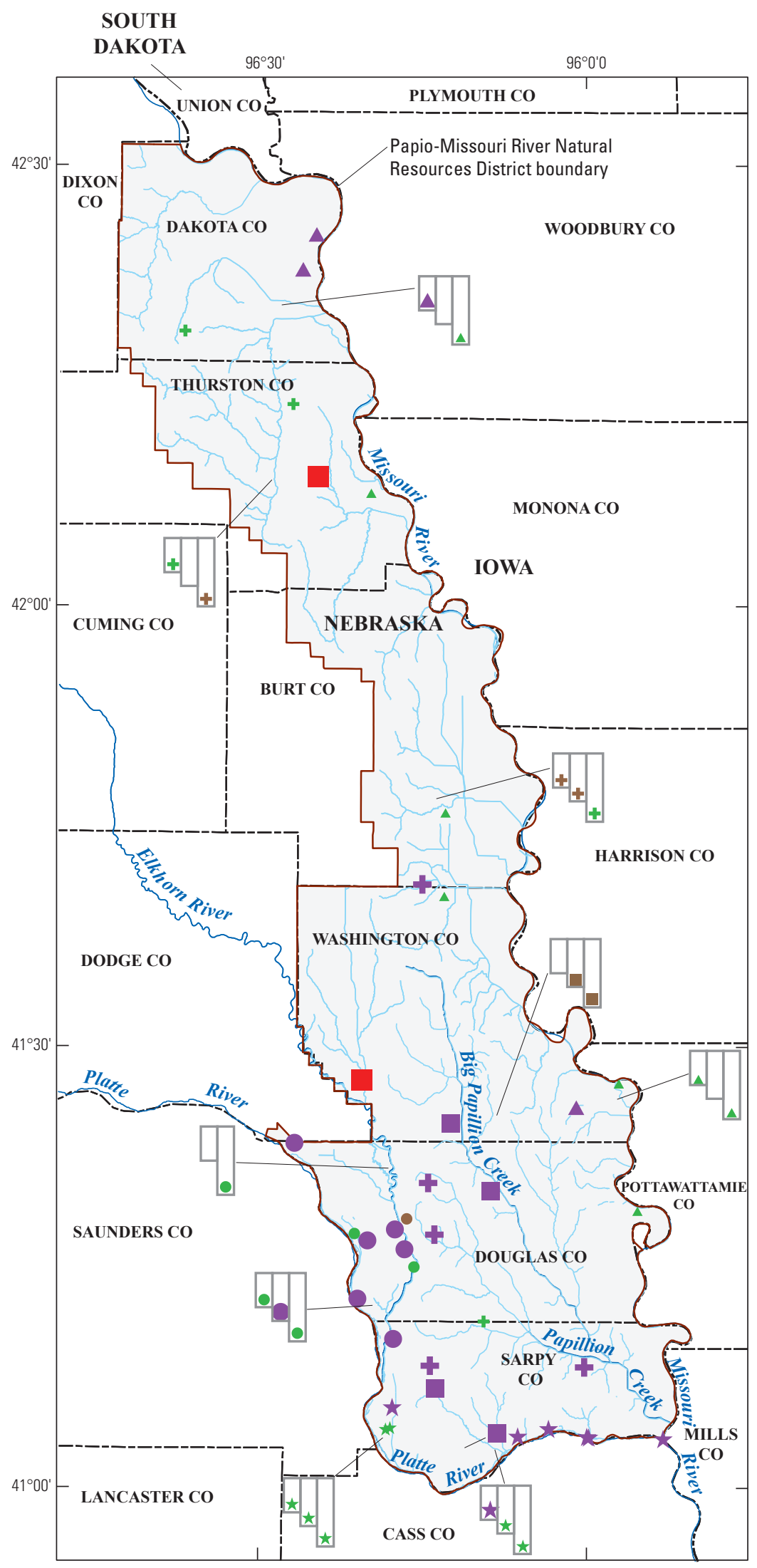

Base from U.S. Geological Survey digital data, 2001, 1:2,000,000

Albers Equal-Area Conic projection

Standard parallels $29^{\circ} 30^{\prime} \mathrm{N}$ and $45^{\circ} 40^{\prime} \mathrm{N}$

Central meridian $97^{\circ} 30^{\prime} \mathrm{W}$

North American Datum of 1983

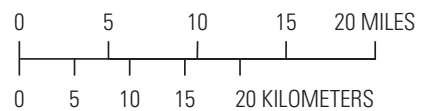

\section{EXPLANATION}

[222Radon activity, in picocuries per liter (pCi/L)]

$\begin{array}{ll} & \text { Dakota aquifer } \\ +\quad & \text { Less than } 150 \\ +\quad & 150 \text { to } 300 \\ +\quad 300 \text { to } 550\end{array}$

Elkhorn River Valley alluvial aquifer

- Less than 150

- 150 to 300

300 to 550

Missouri River Valley alluvial aquifer

A $\quad 150$ to 300

- $\quad 300$ to 550

Platte River Valley alluvial aquifer

$\star \quad 150$ to 300

$\star \quad 300$ to 550

Upland area alluvial aquifers

- Less than 150

- $\quad 150$ to 300

- 300 to 550

550 to 1,200

\section{Wells in well nests}

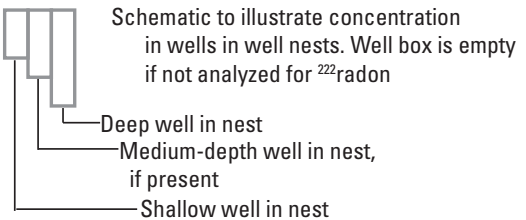

Figure 21. Distribution of ${ }^{222}$ radon activity in the most recent samples in network wells and wells in well nests, Papio-Missouri River Natural Resources District, eastern Nebraska, 1992-2009. 
Table 13. Summary statistics for ${ }^{222}$ radon activity in the most recent samples collected in network wells and in one randomly selected well in each well nest, Papio-Missouri River Natural Resources District, eastern Nebraska, 1992-2009.

[The U.S. Geological Survey parameter code for ${ }^{222}$ radon is 82303 . The proposed U.S. Environmental Protection Agency drinking-water standards and type of standards for ${ }^{222}$ radon are 300 picocuries per liter for the Maximum Contaminant Level and 4,000 picocuries per liter for the Alternative Maximum Contaminant Level (U.S. Environmental Protection Agency, 2009a). The Nebraka Title-118 standard for ${ }^{222}$ radon will be promulgated (Nebraska Department of Environmental Quality, 2006). <, less than]

\begin{tabular}{|c|c|c|c|c|c|c|c|c|c|}
\hline \multirow[b]{2}{*}{ Aquifer(s) } & \multirow{2}{*}{$\begin{array}{c}\text { Number of } \\
\text { samples }\end{array}$} & \multirow{2}{*}{$\begin{array}{l}\text { Number of } \\
\text { detections }\end{array}$} & \multicolumn{7}{|c|}{ Activity, in picocuries per liter } \\
\hline & & & Minimum & $\begin{array}{c}\text { 10th } \\
\text { percentile }\end{array}$ & $\begin{array}{c}\text { 25th } \\
\text { percentile }\end{array}$ & Median & $\begin{array}{c}\text { 75th } \\
\text { percentile }\end{array}$ & $\begin{array}{c}\text { 90th } \\
\text { percentile }\end{array}$ & Maximum \\
\hline Elkhorn River Valley alluvial & 11 & 11 & 100 & 170 & 210 & 330 & 460 & 500 & 530 \\
\hline Missouri River Valley alluvial & 10 & 10 & 230 & 240 & 270 & 290 & 320 & 415 & 480 \\
\hline All aquifers & 48 & 47 & $<80$ & 190 & 255 & 325 & 435 & 480 & 1,200 \\
\hline
\end{tabular}

\section{Summary of Groundwater Quality in Relation to Potential Action Levels}

The PMRNRD groundwater-management plan states that if an analyte concentration exceeds 50 percent of its Nebraska Title-118 standard, a "management, control, or special protection area will be strongly pursued" (Papio-Missouri River Natural Resources District, 1994; Nebraska Department of Environmental Quality, 2006). Analytes with concentrations that exceeded 30 percent of the applicable Nebraska Title-118 standard are identified by the authors in this report (table 14) so that the PMRNRD staff can monitor groundwater in the PMRNRD and plan possible actions should the analyte concentrations continue to rise. The analytical results of the most recent samples collected from the network wells and all the wells in well nests from 1992 to 2009 indicate that, in at least 1 sample, there was a concentration that exceeded 30 percent of the Nebraska Title-118 standard for at least 1 of 3 major ions (chloride, fluoride, and sulfate), 1 nutrient (nitrate), 1 pesticide (atrazine), or 3 trace elements (arsenic, iron, and manganese). Cadmium was not included as a qualified exceedance because its concentration in the associated blank samples indicated contamination potentially occurred during sampling or processing (table 14).

Samples were collected in 1992 for gross alpha, gross beta, and ${ }^{226}$ radium activity and ${ }^{234}$ uranium: ${ }^{238}$ uranium ratio. The Nebraska Title-118 standards are $15 \mathrm{pCi} / \mathrm{L}$ for gross alpha activity, including alpha particles emitted by ${ }^{226}$ radium but excluding alpha particles emitted by radon and uranium; 4 millirem per year (mrem/yr) for gross beta activity; and $5 \mathrm{pCi} / \mathrm{L}$ for combined ${ }^{226}$ radium and ${ }^{228}$ radium activity (appendix 3; Nebraska Department of Environmental Quality, 2006). Verstraeten and Ellis (1995) reported gross alpha results for the 1992 samples and noted that one sample from a well screened in the Dakota aquifer (D-002) likely exceeded the USEPA MCL for gross alpha activity (that is, without radon and uranium emissions). Verstraeten and Ellis (1995) results also indicated that samples from three wells screened in the Dakota aquifer (D-001, D-002, and D-003) likely exceeded $7.5 \mathrm{pCi} / \mathrm{L}$ (50 percent of the Title-118 standard) for gross alpha activity.

Verstraeten and Ellis (1995) reported gross beta results for the 1992 samples; however, the units used were $\mathrm{pCi} / \mathrm{L}$. It is not possible to reliably convert gross beta activity from $\mathrm{pCi} / \mathrm{L}$ to $\mathrm{mrem} / \mathrm{yr}$ units unless the activity of the primary beta emitter species (for example, ${ }^{40}$ potassium, ${ }^{137}$ cesium, ${ }^{131}$ iodine, or ${ }^{90}$ strontium) also was measured. Such data were not included in Verstraeten and Ellis (1995). For some public water systems, USEPA uses gross beta emissions as a screening measure; if gross beta emissions are less than $50 \mathrm{pCi} / \mathrm{L}$ for a given sample, not including ${ }^{40}$ potassium activity (U.S. Environmental Protection Agency, 2001), the activity in the sample will typically be less than $4 \mathrm{mrem} / \mathrm{yr}$, depending on the primary beta emitter species. In 1992, gross beta emissions were less than $31 \mathrm{pCi} / \mathrm{L}$ for all PMRNRD groundwater samples; therefore, activity was likely to be less than $4 \mathrm{mrem} / \mathrm{yr}$. For further information about the gross alpha, gross beta, and ${ }^{226}$ radium activities, and ${ }^{234}$ uranium: $:{ }^{238}$ uranium ratios in the 1992 samples, see Verstraeten and Ellis (1995).

\section{Alternative Approaches to Groundwater Quality Monitoring and Implications}

An objective of the PMRNRD's groundwater-management plan is to monitor water quality of the principal aquifers in the district (Papio-Missouri River Natural Resources District, 1994). Given the analytical results from the most recent samples collected from the network wells and all the wells in well nests from 1992 to 2009, alternative approaches to the current PMRNRD groundwater-quality sampling program that could be considered include the following: 
Table 14. Summary of major ions, nutrients, pesticides, and trace elements results in the most recent selected samples in network wells and in one randomly selected well in each well nest, and number of analyte concentrations that are at least 30, 50, or 100 percent of applicable Federal drinking-water or Nebraska Title-118 standards, PapioMissouri River Natural Resources District, eastern Nebraska, 1992-2009.

[USGS, U.S. Geological Survey; USEPA, U.S. Environmental Protection Agency; mg/L, milligrams per liter; SDWR, Secondary Drinking Water Regulation; --, no result fit criteria or not defined; MCL, Maximum Contaminant Level; DWAT, Drinking Water Advisory Table; Reserved, a standard will be promulgated for this analyte; DWAT-Low sodium diet, maximum concentration advised for individuals on a restricted sodium diet; $\mu \mathrm{g} / \mathrm{L}$, micrograms per liter; LTHA, Lifetime Health Advisory level]

\begin{tabular}{|c|c|c|c|c|c|c|c|c|c|c|c|c|c|}
\hline \multirow{3}{*}{ Constitutent } & \multirow{3}{*}{$\begin{array}{c}\text { USGS } \\
\text { parameter } \\
\text { code }\end{array}$} & \multirow{3}{*}{$\begin{array}{c}\text { Concentration } \\
\text { unit }\end{array}$} & \multirow{3}{*}{$\begin{array}{c}\text { USEPA } \\
\text { drinking-water } \\
\text { standard(s)/ } \\
\text { type of } \\
\text { standard' }^{1}\end{array}$} & \multirow{3}{*}{$\begin{array}{c}\text { Nebraska } \\
\text { Title-118 } \\
\text { standard }^{2}\end{array}$} & \multirow{3}{*}{$\begin{array}{c}\text { Number } \\
\text { of } \\
\text { samples }\end{array}$} & \multicolumn{6}{|c|}{$\begin{array}{c}\text { Number of samples, by aquifer, with analyte concentrations that are at least } \\
30 \text { percent of the highest USEPA' or Nebraska Title-118 standard }{ }^{2}\end{array}$} & \multirow{3}{*}{$\begin{array}{c}\text { Total number of } \\
\text { samples with analyte } \\
\text { concentrations of at } \\
\text { least } 50 \text { percent of } \\
\text { the highest USEPA' } \\
\text { or Nebraska Title-118 } \\
\text { standard }{ }^{2}\end{array}$} & \multirow{3}{*}{$\begin{array}{l}\text { Total number of } \\
\text { samples with analyt } \\
\text { concentrations that } \\
\text { equal or exceed the } \\
\text { highest USEPA }{ }^{1} \text { or } \\
\text { Nebraska Title-118 } \\
\text { standard }{ }^{2}\end{array}$} \\
\hline & & & & & & & & Aquifer(s) & & & & & \\
\hline & & & & & & Dakota & $\begin{array}{l}\text { Elkhorn } \\
\text { River Valley } \\
\text { alluvial }\end{array}$ & $\begin{array}{l}\text { Missouri } \\
\text { River Valley } \\
\text { alluvial }\end{array}$ & $\begin{array}{c}\text { Platte River } \\
\text { Valley } \\
\text { alluvial }\end{array}$ & $\begin{array}{l}\text { Upland } \\
\text { area } \\
\text { alluvial }\end{array}$ & Total & & \\
\hline \multicolumn{14}{|c|}{ Most recent samples for major ions } \\
\hline Chloride & 00940 & $\mathrm{mg} / \mathrm{L}$ & 250/SDWR & 250 & 49 & 2 & -- & 1 & -- & -- & 3 & 1 & -- \\
\hline \multirow[t]{2}{*}{ Fluroide } & 00950 & $\mathrm{mg} / \mathrm{L}$ & 4/MCL & 4 & 49 & 1 & -- & -- & -- & -- & 1 & -- & -- \\
\hline & 00950 & $\mathrm{mg} / \mathrm{L}$ & 2/SDWR & 4 & 49 & 1 & -- & -- & -- & -- & 1 & -- & -- \\
\hline \multirow[t]{2}{*}{ Sodium } & 00930 & $\mathrm{mg} / \mathrm{L}$ & 30-60/DWAT & Reserved & 49 & 9 & 8 & 9 & 8 & 4 & 38 & 19 & 4 \\
\hline & 00930 & $\mathrm{mg} / \mathrm{L}$ & $\begin{array}{l}\text { 20/DWAT-Low } \\
\text { sodium diet }\end{array}$ & Reserved & 49 & 11 & 11 & 10 & 10 & 7 & 49 & 48 & 38 \\
\hline Sulfate & 00945 & $\mathrm{mg} / \mathrm{L}$ & 250/SDWR & 250 & 49 & 4 & 4 & 6 & 2 & -- & 16 & 8 & 4 \\
\hline \multicolumn{14}{|c|}{ Most recent samples for nutrients, summer-to-fall season } \\
\hline $\begin{array}{l}\text { Nitrate plus } \\
\text { nitrite }\end{array}$ & 00631 & $\begin{array}{l}\mathrm{mg} / \mathrm{L}, \text { as } \\
\text { nitrogen }\end{array}$ & 10/MCL & 10 & 200 & 11 & 12 & 4 & 7 & 14 & 48 & 35 & 13 \\
\hline \multicolumn{14}{|c|}{ Most recent samples for pesticides } \\
\hline Atrazine & 39632 & $\mu \mathrm{g} / \mathrm{L}$ & 3/MCL & 3 & 70 & -- & -- & -- & 1 & -- & 1 & 1 & -- \\
\hline \multicolumn{14}{|c|}{ Most recent samples for trace elements } \\
\hline Arsenic & 01000 & $\mu \mathrm{g} / \mathrm{L}$ & 10/MCL & 10 & 49 & -- & 4 & 7 & 6 & -- & 17 & 10 & 3 \\
\hline Boron & 01020 & $\mu \mathrm{g} / \mathrm{L}$ & $1,000 /$ LTHA & -- & 49 & 3 & 1 & -- & -- & 1 & 5 & 3 & -- \\
\hline Cadmium $^{3}$ & 01025 & $\mu \mathrm{g} / \mathrm{L}$ & $5 \mathrm{MCL}$ & 5 & 50 & 1 & 1 & 2 & 1 & -- & 5 & 2 & -- \\
\hline Iron & 01046 & $\mu \mathrm{g} / \mathrm{L}$ & $300 / \mathrm{SDWR}$ & 300 & 50 & 4 & 6 & 11 & 5 & 1 & 27 & 26 & 23 \\
\hline \multirow[t]{2}{*}{ Manganese } & 01056 & $\mu \mathrm{g} / \mathrm{L}$ & 300/LTHA & -- & 50 & 5 & 10 & 11 & 6 & 2 & 34 & 31 & 27 \\
\hline & 01056 & $\mu \mathrm{g} / \mathrm{L}$ & 50/SDWR & 50 & 50 & 6 & 11 & 11 & 6 & 3 & 37 & 37 & 35 \\
\hline Strontium & 01080 & $\mu \mathrm{g} / \mathrm{L}$ & 4,000/LTHA & -- & 50 & 5 & -- & 7 & -- & -- & 12 & 3 & 2 \\
\hline
\end{tabular}

${ }^{1}$ U.S. Environmental Protection Agency, 2009a.

${ }^{2}$ Nebraska Department of Environmental Quality, 2006

${ }^{3}$ These cadimum results are all from samples collected in 1992 and likely reflect contamination during sample collection, processing, or analysis because cadimum was detected at the same order of magnitude in the associated blank sample. 
1. Collect fewer samples for nutrient analysis;

2. Collect samples periodically for analysis of constituents with Federal drinking-water or Nebraska Title-118 standard(s) — consider selecting constituents with one or more 1992 to 2009 results that approached or exceeded the Federal drinking-water or Nebraska Title-118 standard(s) (table 14);

3. Collect samples periodically for analysis of radionuclides activity, especially from wells screened in the Dakota aquifer;

4. Restrict water-quality sampling to wells with at least a minimum of well-construction information (for example, well depth, depth(s) to top and bottom of screen(s), and number of screens) and equipped with a faucet located close to the wellhead and pump, before any water treatment; and

5. Select network wells to be sampled each year using a stratified-random approach (Scott, 1990).

Decreasing the frequency of nutrient sampling could be considered because the distribution of concentrations of nitrate-N, by aquifer, was similar from 1992 to 1994 and from 2007 to 2009 and because there are no significant trends in nitrate-N concentrations for most wells in the well nests. Decreasing the frequency of nutrient sampling, particularly in areas where there is not a significant trend in nitrate- $\mathrm{N}$ concentration, could provide economic benefits.

The analytical results from the most recent samples collected from the network wells and all the wells in well nests from 1992 to 2009 indicate that in at least 1 sample there was a concentration that exceeded 30 percent of the Nebraska Title-118 standard for at least 1 of 3 major ions (chloride, fluoride, and sulfate), 1 nutrient (nitrate), 1 pesticide (atrazine), or 3 trace elements (arsenic, iron, and manganese). Collecting samples periodically from network wells and wells in well nests for analysis of these constituents could be considered to allow the PMRNRD to assess whether these concentrations are changing.

Verstraeten and Ellis (1995) reported that samples from three wells screened in the Dakota aquifer (D-001, D-002, and D-003) likely exceeded $7.5 \mathrm{pCi} / \mathrm{L}$ (50 percent of the Nebraska Title-118 standard) for gross alpha activity. Sampling periodically for radionuclides activity, especially for wells screened in the Dakota aquifer, could be considered to assess current values for gross alpha activity in the groundwater. Additional radionuclide samples also could indicate the extent of activity levels that exceed 50 percent of the Nebraska Title-118 standard, particularly for ${ }^{226}$ radium and ${ }^{228}$ radium activities, which were not measured in 1992 by Verstraeten and Ellis (1995).

Restricting sampling to wells with a minimum of wellconstruction information (for example, well depth, depth to top and bottom of screen, and number of screens) and equipped with a faucet located close to the wellhead and pump, before any water treatment, would allow for on-site measurement of dissolved oxygen in the field. The dissolved oxygen results, with other selected major ion and trace-element results, are useful to evaluate redox processes.

Selecting the network wells to be sampled each year using a stratified-random approach (Scott, 1990) would provide an unbiased and well-distributed set of samples for later analysis and improve representativeness and spatial coverage. A more robust and defensible analysis depends on an unbiased and well-distributed set of samples.

\section{Summary}

The U.S. Geological Survey, in cooperation with the Papio-Missouri River Natural Resources District (PMRNRD), conducted this study to map the water-level altitude of 2009 within the Elkhorn River Valley, Missouri River Valley, and Platte River Valley alluvial aquifers; to present the predevelopment potentiometric-surface altitude within the Dakota aquifer; and to describe the age and quality of groundwater in the five principal aquifers of the PMRNRD in eastern Nebraska using data collected from 1992 to 2009. In addition, implications of alternatives to the current PMRNRD groundwaterquality monitoring approach are discussed.

The PMRNRD encompasses approximately 1,790 square miles (4,640 square kilometers) in eastern Nebraska and includes all or parts of seven counties. In the PMRNRD, groundwater altitude, relative to National Geodetic Vertical Datum of 1929, ranged from about 1,080 feet (ft) to $1,180 \mathrm{ft}$ in the Elkhorn River Valley alluvial aquifer and from about $960 \mathrm{ft}$ to 1,080 ft in the Missouri River Valley and Platte River Valley alluvial aquifers. Groundwater flow generally is toward or parallel to the rivers. In the PMRNRD, the estimated altitude of the potentiometric surface of the Dakota aquifer, predevelopment, ranged from about $1,100 \mathrm{ft}$ to $1,200 \mathrm{ft}$. Groundwater flow in the Dakota aquifer is generally toward the east.

To assess groundwater age and quality, groundwater samples were collected from a total of 217 wells from 1992 to 2009 for analysis of various analytes. Groundwater samples collected in the PMRNRD from 1992 to 2009 and interpreted in this report were analyzed for age-dating analytes (chlorofluorocarbons), dissolved gases, major ions, trace elements, nutrients, stable isotope ratios, pesticides and pesticide degradates, volatile organic compounds (VOCs), explosives, and ${ }^{222}$ radon.

Apparent groundwater age was assessed from concentrations of chlorofluorocarbons and dissolved gases measured in samples collected in 2000 from selected wells in well nests. Apparent groundwater-recharge dates (as of 2000) ranged from early 1960s to early 1980s in the Dakota aquifer, early 1960 s to 1970 s in the Elkhorn River Valley alluvial aquifer, older than 1940 and late 1960s to early 1970s in the Missouri River Valley alluvial aquifer, mid-to-late 1950s and early-tomid 1970s in the Platte River Valley alluvial aquifer, and early 1970 s in one of the upland area alluvial aquifers. 
Concentrations of major ions in the most recent samples collected from 1992 to 2009 indicate that the predominant water type was calcium bicarbonate. Major ion results indicate that concentrations of sulfate in 4 wells exceeded the U.S. Environmental Protection Agency (USEPA) Secondary Drinking Water Regulation (SDWR) and Nebraska Title-118 standards, and concentrations of sodium in 4 wells exceeded USEPA nonenforceable Drinking Water Advisory Table standards. In addition, the chloride concentration in 1 sample exceeded 50 percent of the USEPA SDWR, and the fluoride concentration in 1 sample exceeded 30 percent of the USEPA Maximum Contaminant Level (MCL) and Nebraska Title-118 standard. On the basis of the concentrations of major ions, calcium and magnesium, all samples were classified as "hard" or "very hard" water.

Eighteen of the 21 trace elements analyzed in samples from PMRNRD wells have USEPA drinking-water standards. Sixteen of the trace elements with USEPA standards were detected in the selected samples. In the samples selected for trace-element analysis, the only trace-element concentration that exceeded an enforceable USEPA drinking-water standard (MCL) was for arsenic; this occurred in 4 percent of the samples. In these selected trace-element samples, the trace elements detected at concentration(s) that exceeded a nonenforceable USEPA drinking-water standard (SDWR or Lifetime Health Advisory level) were iron (46 percent of wells), manganese (70 percent), and strontium (4 percent). The trace elements without a USEPA drinking-water standard that were detected in the selected trace-element samples are cobalt, lithium, and vanadium. The only trace elements that were not detected in any of the selected samples are lead and nickel.

From 1992 to 2009, groundwater samples from the PMRNRD network wells and well nests were analyzed for as many as four nitrogen and phosphorus compounds - ammonia, nitrate, nitrite, and orthophosphate. Nitrate-N concentrations in the most recent nutrient samples collected from the network wells and from one randomly selected well in the well nests from 1992 to 2009 for most wells (80 percent) ranged from less than 0.06 to 8.55 milligrams per liter $(\mathrm{mg} / \mathrm{L})$, with a median value of $0.12 \mathrm{mg} / \mathrm{L}$. Concentrations of nitrate- $\mathrm{N}$ in 13 (7 percent) nutrient samples, 1992 to 2009, were greater than or equal to the USEPA MCL and Nebraska Title-118 standard of $10 \mathrm{mg} / \mathrm{L}$, and concentrations of nitrate-N in 35 (18 percent) nutrient samples, 1992 to 2009, were greater than or equal to $5 \mathrm{mg} / \mathrm{L}$, which is the PMRNRD action level for possible management implementation to reduce nitrate concentrations in groundwater.

The spatial distribution of denitrification in the PMRNRD was assessed using (1) concentrations of dissolved oxygen, (2) concentrations of dissolved nitrogen gas and methane, and (3) $\delta^{15} \mathrm{~N}_{\text {AIR }}$ in nitrate and dissolved nitrogen gas. In the nutrient samples, 1992 to 2009, the water was anoxic in 85 (44 percent) of the 191 samples with dissolved oxygen results. Excess nitrogen gas or presence of methane gas indicate that at least some denitrification likely was occurring in groundwater within the capture area for wells in the well nests with dissolved gas analysis.

The fractional decrease in the amount of nitrate-N (" $f$ ") is greater than 0.5 for all the sampled wells in well nests, except D-T3, E-V1, P-A2, P-A1, P-S2, and P-S1. Estimated " $f$ " is 0.1 or less for wells D-T3, P-S2, and P-S1; this result (evidence of little denitrification) agrees with the oxic redox classification of these wells in samples from 1999 to 2009.

Statistical tests for a temporal difference, using the nutrient samples for 1992 to 1994 and 2007 to 2009, determined no significant change in the nitrate- $\mathrm{N}$ concentration distribution for any of the five PMRNRD aquifers. In addition, no significant difference was determined for the nitrate-N concentration distribution by aquifer (1) between the 1992 to 1994 and 1992 to 2009 results or (2) between the 2007 to 2009 and 1992 to 2009 results.

For each of the wells in well nests, the final summer-tofall samples in each year from 1999 to 2009 were selected to assess whether there was a statistically significant temporal trend in nitrate- $\mathrm{N}$ concentrations. The trends in nitrate- $\mathrm{N}$ concentrations were negative for the wells in the well nests near Venice and Walthill-wells E-V1, E-V2, and D-W2. The trends in nitrate-N concentrations were positive for the wells in the well nest near Springfield - wells P-S1, P-S2, and P-S3. No significant temporal trends in nitrate- $\mathrm{N}$ concentration were found for the remaining wells in well nests.

Of the 61 pesticides or pesticide degradates analyzed from 2007 to 2009, 21 were detected. Three of the 21 pesticides detected (alachlor, atrazine, and metolachlor) have established health-based criteria; all detections of these compounds were at concentrations less than their USEPA standards. From 2007 to 2009, 1 or more pesticide compounds were detected in 16 of the 82 network wells and in 18 of the 26 wells in well nests. From 2007 to 2009, the individual pesticide compounds that were detected most frequently were alachlor ethane sulfonic acid, a degradate of alachlor; deethylcyanazine acid, a degradate of cyanazine; and atrazine.

In 2008 and 2009, samples from the wells E-V1, E-V2, and E-V3, which are wells in a well nest about 8 miles northeast of the Nebraska Ordnance Plant site, were analyzed for explosives and VOCs. No explosives or VOCs were detected in either the 2008 or 2009 samples.

${ }^{222}$ Radon activity in the most recent samples collected from the network wells and in one randomly selected well in each well nest ranged from less than 80 to 1,200 picocuries per liter $(\mathrm{pCi} / \mathrm{L})$. The median ${ }^{222}$ radon level in the selected wells was $325 \mathrm{pCi} / \mathrm{L}$, which exceeds the lower proposed USEPA MCL of $300 \mathrm{pCi} / \mathrm{L}$.

Analytes with concentrations that exceeded 30 percent of the applicable Nebraska Title-118 standard were identified so that the PMRNRD can plan to monitor groundwater in the area and consider possible actions should the analyte concentrations continue to rise. The analytical results from the 
most recent samples collected in the network wells and all the wells in well nests from 1992 to 2009 indicate that in at least 1 sample there was a concentration that exceeded 30 percent of the Nebraska Title-118 standard for at least 1 of 3 major ions (chloride, fluoride, and sulfate), 1 nutrient (nitrate-N), 1 pesticide (atrazine), or 3 trace elements (arsenic, iron, and manganese). In addition, 30 percent of the USEPA MCL or Nebraska Title-118 standard for gross alpha activity likely was exceeded in samples from three wells screened in the Dakota aquifer.

Study findings indicate that the following alternatives to the current PMRNRD groundwater-sampling approach could be considered: (1) collect fewer samples for nutrient analysis; (2) collect samples periodically for analysis of constituents with Federal drinking-water or Nebraska Title-118 standard(s), particularly constituents with one or more 1992 to 2009 result(s) that approached or exceeded the Federal drinking-water or Nebraska Title-118 standard(s); (3) collect samples periodically for determining radionuclides activity, especially from wells screened in the Dakota aquifer; (4) restrict water-quality sampling to wells with at least a minimum of well-construction information and equipped with a faucet located close to the wellhead and pump, and (5) select network wells to be sampled each year using a stratified-random approach.

\section{References Cited}

Abraxis Corporation, 2010a, Atrazine ELISA user guide: Warminster, Pa., Abraxis Corporation, accessed July 2010 at http://www.abraxiskits.com/moreinfo/PN500001USER.pdf.

Abraxis Corporation, 2010b, Metolachlor ELISA user guide: Warminster, Pa., Abraxis Corporation, accessed July 2010 at http://www.abraxiskits.com/moreinfo/PN500061USER.pdf.

Agency for Toxic Substances and Disease Registry, 2004, Strontium: U.S. Department of Health and Human Services, Public Health Service, ToxFAQs, 2 p., accessed October 2010 at http://www.atsdr.cdc.gov/toxfaqs/tfacts159.pdf.

Agency for Toxic Substances and Disease Registry, 2008, Public health statement, Chap. 1 of Draft toxicological profile for manganese: U.S. Department of Health and Human Services, Public Health Service, 10 p., accessed October 2010 at http://www.atsdr.cdc.gov/toxprofiles/tp151-c1-b.pdf.

Akritas, M.G., Murphy, S.A., and LaValley, M.P., 1995, The Theil-Sen estimator with doubly-censored data and applications to astronomy: Journal of the American Statistical Association, v. 90, p. 170-177.

American Society for Testing and Materials, 1998, Standard test method for radon in drinking water: West Conshohocken, Pa., ASTM Standard D5072-98, 5 p. (Also available at http://www.astm.org/Standards/D5072.htm.)
Ayotte, J.D., Flanagan, S.M., and Morrow, W.S., 2007, Occurrence of uranium and ${ }^{222}$ radon in glacial and bedrock aquifers in the northern United States, 1993-2003: U.S. Geological Survey Scientific Investigations Report 2007-5037, 84 p. (Also available at http://pubs.usgs.gov/ sir/2007/5037/.)

Bartos, T.T., Eddy-Miller, C.A., Norris, J.R., Gamper, M.E., and Hallberg, L.L., 2004, Water-quality characteristics of quaternary unconsolidated-deposit aquifers and lower tertiary aquifers of the Bighorn Basin, Wyoming and Montana, 1999-2001: U.S. Geological Survey Scientific Investigations Report 2004-5252, 155 p. (Also available at http:// pubs.usgs.gov/sir/2004/5252/.)

Böhlke, J.K., Mroczkowski, S.J., and Coplen, T.B., 2003, Oxygen isotopes in nitrate, new reference materials for ${ }^{18} \mathrm{O}:{ }^{17} \mathrm{O}:{ }^{16} \mathrm{O}$ measurements and observations on nitrate-water equilibration: Rapid Communications in Mass Spectrometry, v. 17, p. 1,835-1,846.

Boohar, J.A., 1999, Water resources data, Nebraska, water year 1998: U.S. Geological Survey Water-Data Report NE-98-1, 396 p.

Boohar, J.A., 2000, Water resources data, Nebraska, water year 1999: U.S. Geological Survey Water-Data Report NE-99-1, 580 p.

Boohar, J.A., Hoy, C.G., and Jelinek, F.J., 1995, Water resources data, Nebraska, water year 1994: U.S. Geological Survey Water-Data Report NE-94-1, 462 p.

Boohar, J.A., Hoy, C.G., and Jelinek, F.J., 1996, Water resources data, Nebraska, water year 1995: U.S. Geological Survey Water-Data Report NE-95-1, 364 p.

Boohar, J.A., Hoy, C.G., and Steele, G.V., 1993, Water resources data, Nebraska, water year 1992: U.S. Geological Survey Water-Data Report NE-92-1, 378 p.

Boohar, J.A., and Walczyk, V.C., 1997, Water resources data, Nebraska, water year 1996: U.S. Geological Survey WaterData Report NE-96-1, 402 p.

Boohar, J.A., and Walczyk, V.C., 1998, Water resources data, Nebraska, water year 1997: U.S. Geological Survey WaterData Report NE-97-1, 508 p.

Burchett, R.R., 1965, Correlation of formations drilled in test holes for Interstate 80 bridge between Omaha, Nebraska, and Council Bluffs, Iowa: Lincoln, Nebr., University of Nebraska-Lincoln, Conservation and Survey Division, Nebraska Geological Survey Paper 17, 30 p.

Burchett, R.R., Dreeszen, V.H., Souders, V.L., and Prichard, G.E., 1988, Bedrock geologic map showing configuration of the bedrock surface in the Nebraska part of the Sioux City 1-degree x 2-degrees quadrangle: U.S. Geological Survey Miscellaneous Investigations Series Map I-1879, scale 1:250,000. 
Burchett, R.R., Reed, E.C., Dreeszen, V.H., and Prichard, G.E., 1975, Bedrock geologic map showing thickness of overlying Quaternary deposits, Fremont quadrangle and part of Omaha quadrangle: U.S. Geological Survey Miscellaneous Investigations Series Map I-905, scale $1: 250,000$.

Burchett, R.R., and Smith, F.A., 1989a, Washington County test-hole log: Lincoln, Nebr., University of Nebraska-Lincoln, Conservation and Survey Division, Nebraska Geological Survey Test-Hole Report 89, 36 p.

Burchett, R.R., and Smith, F.A., 1989b, Sarpy County testhole log: Lincoln, Nebr., University of Nebraska-Lincoln, Conservation and Survey Division, Nebraska Geological Survey Test-Hole Report 77, 70 p.

Burchett, R.R., and Smith, F.A., 1989c, Douglas County testhole log: Lincoln, Nebr., University of Nebraska-Lincoln, Conservation and Survey Division, Nebraska Geological Survey Test-Hole Report 28, 48 p.

Burchett, R.R., and Smith, F.A., 1991a, Burt County test-hole log: Lincoln, Nebr., University of Nebraska-Lincoln, Conservation and Survey Division, Nebraska Geological Survey Test-Hole Report 11, 35 p.

Burchett, R.R., and Smith, F.A., 1991b, Dakota County testhole log: Lincoln, Nebr., University of Nebraska-Lincoln, Conservation and Survey Division, Nebraska Geological Survey Test-Hole Report 22, 9 p.

Burchett, R.R., and Smith, F.A., 1992, Thurston County testhole log: Lincoln, Nebr., University of Nebraska-Lincoln, Conservation and Survey Division, Nebraska Geological Survey Test-Hole Report 87, 37 p.

Busenberg, Eurybiades, and Plummer, L.N., 1992, Use of chlorofluorocarbons $\left(\mathrm{CCl}_{3} \mathrm{~F}\right.$ and $\left.\mathrm{CCl}_{2} \mathrm{~F}_{2}\right)$ as hydrologic tracers and age-dating tools - The alluvium and terrace system of central Oklahoma: Water Resources Research, v. 28, no. 9 , p. 2,257-2,283.

Carter, J.M., Delzer, G.C., Kingsbury, J.A., and Hopple, J.A., 2007, Concentration data for anthropogenic organic compounds in ground water, surface water, and finished water of selected community water systems in the United States, 2002-05: U.S. Geological Survey Data Series 268, 30 p. (Also available at http://pubs.usgs.gov/ds/2007/268/.)

Casciotti, K.L., Sigman, D.M., Hastings, M.G., Böhlke, J.K., and Hilkert, A.W., 2002, Measurement of the oxygen isotopic composition of nitrate in seawater and freshwater using the denitrifier method: Analytical Chemistry, v. 74, p. 4,905-4,912.

Center for Advanced Land Management Information Technologies, 2007, 2005 Nebraska land use patterns: Lincoln, Nebr., University of Nebraska-Lincoln, geospatial data, accessed March 2010 at http://calmit.unl.edu/2005landuse/ metadata/Nebraska_2005_landuse.html.
Centers for Disease Control and Prevention, 2010, Private well water and fluoride FAQs: Centers for Disease Control and Prevention fact sheet, accessed October 2010 at http:// www.cdc.gov/fluoridation/fact_sheets/wellwater.htm.

Chapelle, F.H., McMahon, P.B., Dubrovsky, N.M., Fujii, R.F., Oaksford, E.T., and Vroblesky, D.A., 1995, Deducing the distribution of terminal electron-accepting processes in hydrologically diverse groundwater systems: Water Resources Research, v. 31, p. 359-371.

Childress, C.J.O., Foreman, W.T., Connor, B.F., and Maloney, T.J., 1999, New reporting procedures based on longterm method detection levels and some considerations for interpretations of water-quality data provided by the U.S. Geological Survey National Water Quality Laboratory: U.S. Geological Survey Open-File Report 99-193, 19 p. (Also available at http://water.usgs.gov/owq/OFR_99-193/ index.html.)

Clark, I.D., and Fritz, Peter, 1997, Environmental isotopes in hydrogeology: Boca Raton, Fla., Lewis Publishers, 328 p.

Condra, G.E., 1908, Geology and water resources of a portion of the Missouri River valley in northeastern Nebraska: U.S. Geological Survey Water-Supply Paper 215, 59 p. (Also available at http://pubs.er.usgs.gov/djvu/WSP/ wsp_215.djvu.)

Condra, G.E., and Reed, E.C., 1959, The geological section of Nebraska, with current revisions by E.C. Reed: Lincoln, Nebr. University of Nebraska-Lincoln, Conservation and Survey Division, Nebraska Geological Survey Bulletin 14A, 86 p.

Condra, G.E., Schramm, E.F., and Lugn, A.L., 1931, Deep wells of Nebraska: Lincoln, Nebr., University of NebraskaLincoln, Conservation and Survey Division, Nebraska Geological Survey Bulletin 4, 289 p.

Connor, B.F., Rose, D.L., Noriega, M.C., Murtagh, L.K., and Abney, S.R., 1998, Methods of analysis by the U.S. Geological Survey National Water Quality Laboratory-Determination of 86 volatile organic compounds in water by gas chromatography/mass spectrometry, including detections less than reporting limits: U.S. Geological Survey OpenFile Report 97-829, 78 p. (Also available at http://nwql. usgs.gov/Public/pubs/OFR97-829/OFR97-829.html.)

CropLife Foundation, 2010, National pesticide use database, 2002: Washington, D.C., Crop Protection Research Institute of the CropLife Foundation data, accessed July 2010 at http://www.croplifefoundation.org/cpri_npud2002.htm.

DeSimone, L.A., 2009, Quality of water from domestic wells in principal aquifers of the United States, 1991-2004: U.S. Geological Survey Scientific Investigations Report 2008-5227, 139 p. (Also available at http://pubs.usgs.gov/ sir/2008/5227.) 
Dreeszen, V.H., 1970, The stratigraphic framework of Pleistocene glacial and periglacial deposits in the Central Plains, in Dort, Wakefield, Jr., and Jones, J.K., eds., Pleistocene and recent environments of the central Great Plains: Lawrence, Kans., University of Kansas Press, Special Publication 3, p. 9-22.

Dubrovsky, N.M., Burow, K.R., Clark, G.M., Gronberg, J.M., Hamilton P.A., Hitt, K.J., Mueller, D.K., Munn, M.D., Nolan, B.T., Puckett, L.J., Rupert, M.G., Short, T.M., Spahr, N.E., Sprague, L.A., and Wilber, W.G., 2010, The quality of our Nation's waters-Nutrients in the Nation's streams and groundwater, 1992-2004: U.S. Geological Survey Circular 1350, 174 p. (Also available at http://water.usgs.gov/ nawqa/nutrients/pubs/circ1350.)

Durfor, C.N., and Becker, Edith, 1964, Public water supplies of the 100 largest cities in the United States, 1962: U.S. Geological Survey Water-Supply Paper 1812, 364 p. (Also available at $h t t p: / / p u b s . e r . u s g s . g o v / p u b l i c a t i o n /$ wsp1812.)

Ellis, M.J., 1984, Overview of the Dakota aquifer system in Nebraska, in Jorgensen, D.G., and Signor, D.C., eds., Geohydrology of the Dakota aquifer-C.V. Theis Conference on Geohydrology, 1st, Lincoln, Nebr., 1982, Proceedings: Worthington, Ohio, National Water Well Association, p. $48-55$.

Ellis, M.J., 1986, Hydrogeologic data for the Dakota aquifer system in Nebraska: U.S. Geological Survey Open-File Report 86-526, 100 p.

Emmett, L.F., and Jeffery, H.G., 1969, Reconnaissance of the ground-water resources of the Missouri River alluvium between Kansas City, Missouri and the Iowa border: U.S. Geological Survey Hydrologic Investigations Atlas HA-336, 1 sheet, scale 1:250,000. (Also available at $h t t p: / /$ pubs.er.usgs.gov/djvu/HA/ha_336_plt.djvu.)

Engberg, R.A., 1984, Appraisal of data for ground-water quality in Nebraska: U.S. Geological Survey Water-Supply Paper 2245, 54 p. (Also available at http://pubs.er.usgs.gov/ djvu/WSP/wsp_2245.djvu.)

Engel, G.B., 2001, Water resources data, Nebraska, water year 2000: U.S. Geological Survey Water-Data Report NE-00-1, $428 \mathrm{p}$.

Exner, M.E., 1980, Ground water nitrate-as-nitrogen concentrations, Fremont quadrangle: Lincoln, Nebr., University of Nebraska-Lincoln, Institute of Agriculture and Natural Resources, 1 sheet, scale 1:250,000.

Fan, A.M., and Steinberg, V.E., 1996, Health implications of nitrate and nitrite in drinking water-An update on methemoglobinemia occurrence and reproductive and developmental toxicity: Regulatory Toxicology and Pharmacology, v. 23 , p. $35-43$.
Fenneman, N.M., 1938, Physiography of eastern United States: New York, McGraw-Hill, p. 588-605.

Fishman, M.J., ed., 1993, Methods of analysis by the U.S. Geological Survey National Water Quality Laboratory-Determination of inorganic and organic constituents in water and fluvial sediments: U.S. Geological Survey Open-File Report 93-125, 217 p. (Also available at $h t t p: / /$ pubs.er.usgs.gov/usgspubs/ofr/ofr93125.)

Fishman, M.J., and Friedman, L.C., 1989, Methods for determination of inorganic substances in water and fluvial sediments: U.S. Geological Survey Techniques of WaterResources Investigations, book 5, chap. A1, 545 p. (Also available at http://pubs.usgs.gov/twri/twri5-a1/.)

Focazio, M.J., Welch, A.H., Watkins, S.A., Helsel, D.R., and Horn, M.A., 1999, A retrospective analysis on the occurrence of arsenic in ground-water resources of the United States and limitations in drinking-water-supply characterizations: U.S. Geological Survey Water-Resources Investigations Report, 99-4279, 21 p. (Also available at http://pubs. usgs.gov/wri/wri994279/.)

Freeze, R.A., and Cherry, J.A., 1979, Groundwater: Edgewood Cliffs, N.J., Prentice Hall, 604 p.

Garbarino, J.R., 1999, Methods of analysis by the U.S. Geological Survey National Water Quality Laboratory-Determination of dissolved arsenic, boron, lithium, selenium, strontium, thallium, and vanadium using inductively coupled plasma-mass spectrometry: U.S. Geological Survey Open-File Report 99-93, 31 p. (Also available at http://nwql.usgs.gov/Public/pubs/OFR99-093/OFR99-093. html.)

Garbarino, J.R., and Damrau, D.L., 2001, Methods of analysis by the U.S. Geological Survey National Water Quality Laboratory -Determination of organic plus inorganic mercury in filtered and unfiltered natural water with cold vapor-atomic fluorescence spectrometry: U.S. Geological Survey Water-Resources Investigations Report 01-4132, 16 p. (Also available at $h t t p: / / n w q l . u s g s . g o v / P u b l i c / p u b s /$ WRIR01-4132.html.)

Garbarino, J.R., Kanagy, J.R., and Cree, M.E., 2006, Determination of elements in natural-water, biota, sediment, and soil samples using collision/reaction cell inductively coupled plasma-mass spectrometry: U.S. Geological Survey Techniques and Methods, book 5, chap. B1, 88 p. (Also available at http://pubs.usgs.gov/tm/2006/tm5b1/.)

Gilliom, R.J., Barbash, J.E., Crawford, C.G., Hamilton, P.A., Martin, J.D., Nakagaki, Naomi, Nowell, L.H., Scott, J.C., Stackelberg, P.E., Thelin, G.P., and Wolock, D.M., 2006, Pesticides in the nation's streams and ground water, 1992-2001: U.S. Geological Survey Circular 1291, 172 p. (Also available at $h t t p: / / p u b s . u s g s . g o v / c i r c / 2005 / 1291 /$.) 
Gutentag, E.D., Heimes, F.J., Krothe, N.C., Luckey, R.R., and Weeks, J.B., 1984, Geohydrology of the High Plains aquifer in parts of Colorado, Kansas, Nebraska, New Mexico, Oklahoma, South Dakota, Texas, and Wyoming: U.S. Geological Survey Professional Paper 1400-B, 63 p. (Also available at http://pubs.er.usgs.gov/djvu/PP/pp_1400_b.djvu.)

Helgesen, J.O., Leonard, R.B., and Wolf, R.J., 1993, Hydrology of the Great Plains aquifer system in Nebraska, Colorado, Kansas, and adjacent areas: U.S. Geological Survey Professional Paper 1414-E, 80 p. (Also available at $h t t p: / /$ pubs.er.usgs.gov/djvu/PP/pp_1414_e.djvu.)

Helsel, D.R., 2005a, Insider censoring-Distortion of data with nondetects: Human and Ecological Risk Assessment, v. 11, p. $1,127-1,137$.

Helsel, D.R., 2005b, Nondetects and data analysis: Hoboken, N.J., Wiley-Interscience, $250 \mathrm{p}$.

Helsel, D.R., and Cohn, T.A., 1988, Estimation of descriptive statistics for multiple censored water quality data: Water Resources Research, v. 24, no. 12, p. 1,997-2,004.

Helsel, D.R., and Hirsch, R.M., 1992, Statistical methods in water resources: Amsterdam, Elsevier Science, 529 p. (Also available at http://pubs.usgs.gov/twri/twri4a3/.)

Hem, J.D., 1985, Study and interpretation of the chemical characteristics of natural water ( $3 \mathrm{~d}$ ed.): U.S. Geological Survey Water-Supply Paper 2254, 263 p. (Also available at http://pubs.usgs.gov/wsp/wsp2254/.)

High Plains Regional Climate Center, 2010a, Omaha Eppley Airfield Nebraska (256255) period of record [1948-2009] monthly climate summary: Lincoln, Nebr., High Plains Regional Climate Center data, accessed October 2010 at http://www.hprcc.unl.edu/cgi-bin/cli_perl_lib/cliMAIN. pl?ne6255.

High Plains Regional Climate Center, 2010b, Sioux City WSO Airport, Iowa (137708) period of record [1948-2009] monthly climate summary: Lincoln, Nebr., High Plains Regional Climate Center data, accessed October 2010 at http://www.hprcc.unl.edu/cgi-bin/cli_perl_lib/cliMAIN. pl?ia7708.

Hitch, D.E., Hull, S.H., Steele, G.V., and Turner, M.J., 2002, Water resources data, Nebraska, water year 2001: U.S. Geological Survey Water-Data Report NE-01-1, 440 p.

Hitch, D.E., Hull, S.H., and Walczyk, V.C., 2003, Water resources data, Nebraska, water year 2002: U.S. Geological Survey Water-Data Report NE-02-1, 437 p. (Also available at http://pubs.usgs.gov/wdr/WDR-NE-02/.)

Hitch, D.E., Hull, S.H., Walczyk, V.C., Miller, J.D., and Drudik, R.A., 2004, Water resources data, Nebraska, water year 2003: U.S. Geological Survey Water-Data Report NE-03-1, 470 p. (Also available at http://pubs.usgs.gov/ wdr/wdr-ne-03-1/.)
Hitch, D.E., Walczyk, V.C., Drudik, R.A., Miller, J.D., and Hull, S.H., 2005, Water resources data, Nebraska, water year 2004: U.S. Geological Survey Water-Data Report NE-04-1, 684 p. (Also available at http://pubs.usgs.gov/ wdr/2004/wdr-ne-04-1/.)

Hopke, P.K., Borak, T.B., Doull, J., Cleaver, J.E., Eckerman, K.F., Gundersen, L.C.S., Harley, N.H., Hess, C.T., Kinner, N.E., Kopecky, K.J., McKone, T.E., Sextro, R.G., and Simon, S.L., 2000, Health risks due to radon in drinking water: Environmental Science and Technology, v. 34, no. 6, p. 921-926.

Jorgensen, D.G., Helgesen, J.O., and Imes, J.L., 1993, Regional aquifers in Kansas, Nebraska, and parts of Arkansas, Colorado, Missouri, New Mexico, Oklahoma, South Dakota, Texas, and Wyoming-Geohydrologic framework: U.S. Geological Survey Professional Paper 1414-B, 72 p. (Also available at http://pubs.er.usgs.gov/djvu/PP/ pp_1414_b_plt.djvu.)

Jorgensen, D.G., Helgesen, J.O., Signor, D.C., Leonard, R.B., Imes, J.L., and Christenson, S.C., 1996, Analysis of regional aquifers in the central Midwest of the United States in Kansas, Nebraska, and parts of Arkansas, Colorado, Missouri, New Mexico, Oklahoma, South Dakota, Texas, and Wyoming - Summary: U.S. Geological Survey Professional Paper 1414-A, 67 p. (Also available at http://pubs.er.usgs. gov/djvu/PP/pp_1414_a.djvu.)

Jurgens, B.C., McMahon, P.B., Chapelle, F.H., and Eberts, S.M., 2009, An Excel workbook for identifying redox processes in groundwater: U.S. Geological Survey Open-File Report 2009-1008, 8 p. (Also available at http://pubs.usgs. gov/of/2009/1004/.)

Kelly, W.R., Holm, T.R., Wilson, S.D., and Roadcap, G.S., 2005, Arsenic in glacial aquifers-Sources and geochemical controls: Ground Water, v. 43, no. 4, p. 500-510.

Kendall, Carol, and Aravena, Ramon, 2000, Nitrate isotopes in groundwater systems, in Cook, P.G., and Herczeg, A.L., eds., Environmental tracers in subsurface hydrology: Boston, Kluwer Academic Publishers, p. 261-297.

Kendall, Carol, and Caldwell, E.A., 1998, Fundamentals of isotope geochemistry, chap. 2 of Kendall, Carol, and McDonnell, J.J., eds., Isotope tracers in catchment hydrology: Amsterdam, Elsevier, p. 51-86.

Kendall, Carol, and McDonnell, J.J., 1998, Isotope tracers in catchment hydrology: Amsterdam, Elsevier, 839 p.

Lee, E.A., and Strahan, A.P., 2003, Methods of analysis by the U.S. Geological Survey Organic Geochemistry Research Group - Determination of acetamide herbicides and their degradation products in water using online solid-phase extraction and liquid chromatography/mass spectrometry: U.S. Geological Survey Open-File Report 03-173, 17 p. (Also available at http://ks.water.usgs.gov/pubs/reports/of.03-173.pdf.) 
Lee, E.A., Strahan, A.P., and Thurman, E.M., 2002, Methods of analysis by the U.S. Geological Survey Organic Geochemistry Research Group-Determination of triazine and phenylurea herbicides and their degradation products in water using solid-phase extraction and liquid chromatography/mass spectrometry: U.S. Geological Survey Open-File Report 02-436, 26 p. (Also available at http://ks.water.usgs. gov/pubs/reports/of.02-436.pdf.)

Madigan, M.T., Martinko, J.M., and Parker, Jack. 2000, Brock Biology of microorganisms (9th ed.): Upper Saddle River, N.J., Prentice Hall, 991 p.

McMahon, P.B., Böhlke, J.K., and Carney, C.P, 2007, Vertical gradients in water chemistry and age in the northern High Plains aquifer, Nebraska, 2003: U.S. Geological Survey Scientific Investigations Report 2005-5294, 58 p. (Also available at $h t t p: / / p u b s . u s g s . g o v /$ sir/2006/5294/.)

McMahon, P.B., Cowdery, T.K., Chapelle, F.H., and Jurgens, B.C., 2009, Redox conditions in selected principal aquifers of the United States: U.S. Geological Survey Fact Sheet 2009-3041, 6 p. (Also available at http://pubs.usgs. gov/fs/2009/3041/.)

Miller, R.D., 1964, Geology of the Omaha-Council Bluffs area, Nebraska-Iowa: U.S. Geological Survey Professional Paper 472, 70 p. (Also available at http://pubs.er.usgs.gov/ djvu/PP/pp_472.djvu.)

National Research Council, 1999, Risk assessment of radon in drinking water: Washington, D.C., National Academy Press, $296 \mathrm{p}$.

National Research Council, 2001, Arsenic in drinking water, 2001 update: Washington, D.C., National Academy Press, $226 \mathrm{p}$.

Nebraska Department of Environmental Quality, 2006, Title 118, Chapter 4, Narrative and numerical standards (revised): Lincoln, Nebr., Nebraska Department of Environmental Quality, accessed July 2010 at $h t t p: / / w w w . d e q . s t a t e$. ne.us/RuleAndR.nsf/pages/118-Ch-4.

Nebraska Department of Environmental Quality and University of Nebraska-Lincoln, Conservation and Survey Division, 1980a, Configuration of the base of the principal aquifer, 1979, Fremont-Omaha quadrangle: Lincoln, Nebr., University of Nebraska-Lincoln, Conservation and Survey Division, 1 sheet, scale 1:250,000.

Nebraska Department of Environmental Quality and University of Nebraska-Lincoln, Conservation and Survey Division, 1980b, Configuration of the base of the principal aquifer, 1979, Sioux City quadrangle: Lincoln, Nebr., University of Nebraska-Lincoln, Conservation and Survey Division, 1 sheet, scale 1:250,000.
Nebraska Department of Environmental Quality and University of Nebraska-Lincoln, Conservation and Survey Division, 1980c, Thickness of the principal aquifer, 1979, Fremont-Omaha quadrangle: Lincoln, Nebr., University of Nebraska-Lincoln, Conservation and Survey Division, 1 sheet, scale 1:250,000.

Nebraska Department of Environmental Quality and University of Nebraska-Lincoln, Conservation and Survey Division, 1980d, Thickness of the principal aquifer, 1979, Sioux City quadrangle: Lincoln, Nebr., University of NebraskaLincoln, Conservation and Survey Division, 1 sheet, scale 1:250,000.

Nebraska Department of Natural Resources, 2010, Registered groundwater well data base: Lincoln, Nebr., Nebraska Department of Natural Resources, data accessed September 2010 at http://dnrdata.dnr.ne.gov/wellscs/Menu.aspx.

Nolan, B.T., and Hitt, K.J., 2006, Vulnerability of shallow groundwater and drinking-water wells to nitrate in the United States: Environmental Science and Technology, v. 40 , no. 24 , p. $7,834-7,840$.

Nolan, B.T., Ruddy, B.C., Hitt, K.J., and Helsel, D.R., 1997, Risk of nitrate in groundwaters of the United States-A national perspective: Environmental Science and Technology, v. 31, no. 8, p. 2,229-2,236.

O'Connor, T.M., 1987, A preliminary study of the hydrogeology of the Dakota Sandstone in Douglas, Sarpy, and Washington Counties, eastern Nebraska: Lincoln, Nebr., University of Nebraska-Lincoln, unpublished M.S. thesis, 147 p.

Otton, J.K., Gundersen, L.C.S., and Schumann, R.R., 1993, The geology of radon: U.S. Geological Survey General Interest Publication, $29 \mathrm{p}$.

Papio-Missouri River Natural Resources District, 1989, Ground-water management plan: Omaha, Nebr., PapioMissouri River Natural Resources District, 78 p.

Papio-Missouri River Natural Resources District, 1994, PapioMissouri River Natural Resources District, ground-water management plan: Omaha, Nebr., Papio-Missouri River Natural Resources District, 82 p.

Plummer, L.N., and Busenberg, Eurybiades, 2000, Chlorofluorocarbons, chap. 15 of Cook, P.G., and Herczeg, A.L., eds., Environmental tracers in subsurface hydrology: Boston, Kluwer Academic Publications, p. 441-478.

Reed, E.C., and Dreeszen, V.H., 1965, Revision of the classification of the Pleistocene deposits of Nebraska: Lincoln, Nebr., University of Nebraska-Lincoln, Conservation and Survey Division, Nebraska Geological Survey Bulletin no. $23,65 \mathrm{p}$. 
Révész, Kinga, and Casciotti, Karen, 2007, Determination of the $\delta\left({ }^{15} \mathrm{~N} /{ }^{14} \mathrm{~N}\right)$ and $\delta\left({ }^{18} \mathrm{O} /{ }^{16} \mathrm{O}\right)$ of nitrate in water, RSIL Lab Code 2900, chap. C17 of Révész, Kinga, and Coplen, Tyler B., eds., Methods of the Reston Stable Isotope Laboratory: U.S. Geological Survey Techniques and Methods, book 10, sec. C, chap. 17, 24 p. (Also available at http://pubs.usgs. gov/tm/2006/tm10c17/.)

Ruddy, B.C., Lorenz, D.L., and Mueller, D.K., 2006, Countylevel estimates of nutrient inputs to the land surface of the conterminous United States, 1982-2001: U.S. Geological Survey Scientific Investigations Report 2006-5012, 17 p. (Also available at $h t t p: / / p u b s . u s g s . g o v / s i r / 2006 / 5012 /$.)

Sandstrom, M.W., Wydoski, D.S., Schroeder, M.P., Zamboni, J.L., and Foreman, W.T., 1994, Methods of analysis by the U.S. Geological Survey National Water Quality Laboratory-Determination of organonitrogen herbicides in water by solid-phase extraction and capillary-column gas chromatography/mass spectrometry with selected-ion monitoring: U.S. Geological Survey Open-File Report 91-519, 26 p. (Also available at $h t t p: / / n w q l . u s g s . g o v / P u b l i c / p u b s /$ OFR91_519.pdf.)

Scott, J.C., 1990, Computerized stratified random site selection approaches for design of a ground-water quality sampling network: U.S. Geological Survey Water-Resources Investigations Report 90-4101, 109 p. (Also available at http://pubs.er.usgs.gov/djvu/WRI/wrir_90_4101.djvu.)

Shroba, R.R., Brandt, T.R., and Blossom, J.C., 2002, Surficial geologic map of the greater Omaha area, Nebraska and Iowa: U.S. Geological Survey Miscellaneous Field Studies Map MF-2391, scale 1:100,000. (Also available at http:// pubs.usgs.gov/mf/2001/mf-2391/.)

Sigman, D.M., Casciotti, K.L., Andreani, M.C., Barford, C., Galanter, M., and Böhlke, J.K., 2001, A bacterial method for the nitrogen isotopic analysis of nitrate in seawater and freshwater: Analytical Chemistry, v. 73, p. 4,145-4,153.

Smith, B.J., and Richards, J.M., 2008, Ground-water flow, 2004-07, and water quality, 1992-2007, in McBaine Bottoms, Columbia, Missouri: U.S. Geological Survey Scientific Investigations Report 2008-5182, 70 p. (Also available at $h t t p: / / p u b s . u s g s . g o v /$ sir/2008/5182/.)

Soller, D.R., and Packard, P.H., 1998, Digital representation of a map showing the thickness and character of Quaternary sediments in the glaciated United States east of the Rocky Mountains: U.S. Geological Survey Digital Data Series DDS-38, available at http://pubs.usgs.gov/dds/ $d d s 38 \%$.

Spaulding, R.F., 1990, Water quality in the lower Platte River Basin with emphasis on agrichemicals: Lincoln, Nebr., University of Nebraska-Lincoln, Conservation and Survey Division, Completion Report, 123 p.
Stanton, J.S., and Qi, S.L., 2007, Ground-water quality of the northern High Plains aquifer, 1997, 2002-04: U.S. Geological Survey Scientific Investigations Report 2006-5138, 60 p. (Also available at $h t t p: / / p u b s . u s g s . g o v / s i r / 2006 / 5138 /$.)

State of Nebraska, variously dated, Nebraska statutory laws, chapter 46, section 46-701 to 46-754: Nebraska State government, accessed May 2011 at http://nebraskalegislature. gov/laws/browse-chapters.php? chapter $=46$.

Struzeski, T.M., DeGiacomo, W.J., and Zayhowski, E.J., 1996, Methods of analysis by the U.S. Geological Survey National Water Quality Laboratory-Determination of dissolved aluminum and boron in water by inductively compled plasmaatomic emission spectrometry: U.S. Geological Survey Open-File Report 96-149, 17 p. (Also available at http:// pubs.er.usgs.gov/djvu/OFR/1996/ofr_96_149.djvu.)

Tesoriero, A.J., Duff, J.H., Wolock, D.M., Spahr, N.E., and Almendinger, J.E., 2009, Identifying pathways and processes affecting nitrate and orthophosphate inputs to streams in agricultural watersheds: Journal of Environmental Quality, v. 38 , p. $1,892-1,900$.

Todd, J.E., 1908, Description of the Elk Point quadrangle, South Dakota, Nebraska, Iowa: U.S. Geological Survey Atlas Folio 156, 8 p.

U.S. Army Corps of Engineers, 2008, Former Nebraska Ordnance Plant, Mead, Nebraska-Facts about the history of the clean-up project: U.S. Army Corps of Engineers fact sheet, accessed February 2012 at http://www.nwk.usace. army.mil/projects/mead/History/Facts_About_the_History Oct_2008.pdf.

U.S. Army Corps of Engineers, 2010, Former Nebraska Ordnance Plant, Mead, Nebraska: U.S. Army Corps of Engineers project overview, accessed March 2011 at $h t t p: / / w w w$. nwk.usace.army.mil/projects/mead/.

U.S. Census Bureau, 2001, U.S. Census 2000, State \& County quickfacts for Nebraska: U.S. Department of Commerce data, accessed July 2010 at http://quickfacts.census.gov/qfd/ states/31000.html.

U.S. Department of Agriculture, 2009, Soil Survey Geographic (SSURGO) Database for Nebraska: Natural Resources Conservation Service data, accessed May 2010 at http://SoilDataMart.nrcs.usda.gov/.

U.S. Department of Agriculture, 2010, Nebraska county data-Crops: National Agricultural Statistical Service Quick Stats, ver. 1.0 data, accessed February 2010 at http:// www.nass.usda.gov/Data_and_Statistics/Quick_Stats/.

U.S. Department of Energy, 1981, Hydrogeochemical and stream sediment reconnaissance basic data for Fremont Quadrangle, Nebraska and Iowa: Oak Ridge, Tenn., National Uranium Resource Evaluation Program, 34 p. 
U.S. Environmental Protection Agency, 1985, National primary drinking water regulations; Fluoride: Federal Register, v. 50, no. 93 and 220, p. 20,164 and 47,142.

U.S. Environmental Protection Agency, 1986 (revised 2007), Test methods for evaluating of solid waste, physical/chemical methods (3d ed., final update IV): U.S. Environmental Protection Agency, Office of Solid Waste and Emergency Response, EPA-SW-846, (3d ed.), variable pagination, accessed May 2011 at http://www.epa.gov/epawaste/hazard/ testmethods/sw846/index.htm.

U.S. Environmental Protection Agency, 2000, Cyanazine; Cancellation Order: Federal Register, v. 65, no. 4, p. 771773. (Also available at $h t t p: / / w w w . g p o . g o v / f d s y s / p k g /$ FR-2000-01-06/pdf/00-274.pdf.)

U.S. Environmental Protection Agency, 2001, Radionuclides rule-A quick reference guide: Washington, D.C., U.S. Environmental Protection Agency, Office of Water, EPA 816-F-01-003, 2 p., accessed May 2011 at $h t t p: / / w w w$. epa.gov/ogwdw/radionuclides/pdfs/qrg_radionuclides.pdf.

U.S. Environmental Protection Agency, 2003, EPA assessment of risks of radon in homes: U.S. Environmental Protection Agency, Office of Air and Radiation, EPA 402-R-03-003, accessed October 2010 at $h t t p: / / w w w . e p a . g o v /$ radiation/ docs/assessment/402-r-03-003.pdf.

U.S. Environmental Protection Agency, 2009a, 2009 Edition of the drinking water standards and health advisories: U.S. Environmental Protection Agency, Office of Water, EPA 822-R-09-011, 12 p., accessed August 2010 at http://www.epa.gov/waterscience/criteria/drinking/ dwstandards2009.pdf.

U.S. Environmental Protection Agency, 2009b, National Primary Drinking Water Regulations: U.S. Environmental Protection Agency, Office of Water, EPA 816-F-09-004, 6 p., accessed October 2010 at http://water.epa.gov/drink/ contaminants/upload/mcl-2.pdf.

U.S. Environmental Protection Agency, 2010a, Consumer's guide to radon reduction-How to fix your home: U.S. Environmental Protection Agency, Office of Radiation and Indoor Air, EPA 402/K-10/005, 20 p., accessed October 2010 at $h t t p: / / w w w . e p a . g o v /$ radon/pdfs/consguid.pdf.

U.S. Environmental Protection Agency, 2010b, Proposed radon in drinking water regulation: U.S. Environmental Protection Agency, Office of Water data, accessed October 2010 at $h t t p: / / w a t e r . e p a . g o v / l a w s r e g s /$ rulesregs/sdwa/ radon/regulations.cfm.

U.S. Environmental Protection Agency, 2011, New fluoride risk assessment and relative source contribution documents: U.S. Environmental Protection Agency, Office of Water, EPA 822-F-11-001, 2 p., accessed March 2011 at http://water.epa.gov/action/advisories/drinking/upload/ fluoridefactsheet.pdf.
U.S. Geological Survey, variously dated, National field manual for the collection of water-quality data: U.S. Geological Survey Techniques of Water-Resources Investigations, book 9, chap. A1-A9. (Also available at http://water.usgs. gov/owq/FieldManual/.)

U.S. Geological Survey, 2006a, Analytical procedures for dissolved gas: U.S. Geological Survey, Reston Chlorofluorocarbon Laboratory, accessed December 2008 at http://water. usgs.gov/lab/dissolved-gas/lab/analytical_procedures/.

U.S. Geological Survey, 2006b, Water-resources data for the United States, water year 2005: U.S. Geological Survey data, accessed September 2010 at http://wdr.water.usgs.gov/ wy2005/search.jsp.

U.S. Geological Survey, 2007, Water-resources data for the United States, water year 2006: U.S. Geological Survey data, accessed September 2010 at http://wdr.water.usgs.gov/ wy2006/search.jsp.

U.S. Geological Survey, 2008, Water-resources data for the United States, water year 2007: U.S. Geological Survey data, accessed September 2010 at http://wdr.water.usgs.gov/ wy2007/search.jsp.

U.S. Geological Survey, 2009a, Analytical procedures for Chlorofluorocarbon (CFCs): U.S. Geological Survey, Reston Chlorofluorocarbon Laboratory, accessed July 2010 at http://water.usgs.gov/lab/chlorofluorocarbons/lab/ analytical_procedures/.

U.S. Geological Survey, 2009b, Water-resources data for the United States, water year 2008: U.S. Geological Survey data, accessed September 2010 at http://wdr.water.usgs.gov/ wy2008/search.jsp.

U.S. Geological Survey, 2010a, National Water Information System data for Nebraska: U.S. Geological Survey data accessed August 2010 at http://waterdata.usgs.gov/ne/nwis.

U.S. Geological Survey, 2010b, Water-resources data for the United States, water year 2009: U.S. Geological Survey data, accessed September 2010 at http://wdr.water.usgs.gov/ wy2009/search.jsp.

U.S. Geological Survey, 2010c, Water use in the United States: U.S. Geological Survey data, accessed September 2010 at http://water.usgs.gov/watuse/.

U.S. Geological Survey, 2011, Air curve data: U.S. Geological Survey, Reston Chlorofluorocarbon Laboratory data, accessed June 2011 at http://water.usgs.gov/lab/software/ air_curve/.

U.S. Geological Survey and Nebraska Department of Natural Resources, 1998, 7.5 Minute digital elevation modelsDEM-10 meter-Index for the State of Nebraska: Lincoln, Nebr., Nebraska Department of Natural Resources geospatial data, accessed May 2010 at ftp://dnrftp.dnr.ne.gov/pub/ data/dems/dem 10 . 
University of Nebraska-Lincoln, Conservation and Survey Division, 1986, The groundwater atlas of Nebraska: Lincoln, Nebr., University of Nebraska-Lincoln, Conservation and Survey Division, Resource Atlas No. 4, 32 p.

University of Nebraska-Lincoln, Conservation and Survey Division, 1996, Thickness of the principal aquifer, 1979: Lincoln, Nebr., University of Nebraska-Lincoln, Conservation and Survey Division geospatial data, accessed October 2010 at http://snr.unl.edu/data/geographygis/NebrGISwater. asp\#ThicknessPrinAquifer.

University of Nebraska-Lincoln, Conservation and Survey Division, 2009, Groundwater-level changes in NebraskaPredevelopment to spring 2009: Lincoln, Nebr., University of Nebraska-Lincoln, Conservation and Survey Division geospatial map, 1 sheet, scale not specified, accessed August 2009 at http://snr.unl.edu/data/download/water/ GWMapArchives/2009GWMaps/Pred_09.jpg.

University of Nebraska-Lincoln, Conservation and Survey Division, 2010a, Configuration of the base of the principal aquifer, 1979: Lincoln, Nebr., University of Nebraska-Lincoln, Conservation and Survey Division geospatial data, accessed October 2010 at http://snr.unl.edu/data/geographygis/NebrGISwater. asp\#ConfigurationoftheBase1979.

University of Nebraska-Lincoln, Conservation and Survey Division, 2010b, Configuration of the water table, 1995: Lincoln, Nebr., University of Nebraska-Lincoln, Conservation and Survey Division, geospatial data, accessed May 2010 at http://snr.unl.edu/data/geographygis/ NebrGISwater.asp\#ConfigurationofWaterTable1995.

University of Nebraska-Lincoln, Conservation and Survey Division, 2010c, Nebraska statewide test-hole database: Lincoln, Nebr., University of Nebraska-Lincoln, Conservation and Survey Division geospatial data, accessed October 2010 at http://snr.unl.edu/data/geographygis/ NebraskaTestHole/NebraskaTestHoleIntro.asp.
Verstraeten, I.M., and Ellis, M.J., 1995, Reconnaissance of ground-water quality in the Papio-Missouri River Natural Resources District, eastern Nebraska, July through September 1992: U.S. Geological Survey Water-Resources Investigations Report 94-4197, 90 p. (Also available at http:// pubs.er.usgs.gov/djvu/WRI/wrir_94_4197.djvu.)

Watermolen, John, 2005, Hydrologic unit boundariesNational Atlas of the United States: U.S. Geological Survey data, accessed February 2012 at http://nationalatlas.gov/ atlasftp.html? openChapters = chpwater\#chpwater.

Welch, A.H., Westjohn, D.B., Helsel, D.R., and Wanty, R.B., 2000, Arsenic in ground water of the United StatesOccurrence and geochemistry: Ground Water, v. 38, no. 4, p. 589-604.

Whittaker, E.L, Akridge, J.D., and Giovino, J., 1989, Two test procedures for radon in drinking water, Interlaboratory collaborative study: Washington, D.C., U.S. Environmental Protection Agency, EPA/600/2-87/082, 54 p.

World Health Organization, 2008, Guidelines for drinking-water quality, Vol. 1, Recommendations (3d ed): Geneva, World Health Organization, 515 p. (Also available at http://www.who.int/water_sanitation_health/dwq/ gdwq3rev/en/.)

Ziegler, A.C., Wallace, W.C., Blevins, D.W., and Maley, R.D., 1993, Occurrence of pesticides, nitrite plus nitrate, arsenic, and iron in water from two reaches of the Missouri River alluvium, northwestern Missouri-July 1988 and June-July 1989: U.S. Geological Survey Open-File Report 93-101, 30 p. (Also available at http://pubs.er.usgs.gov/djvu/ OFR/1993/ofr_93_101.djvu.) 
Appendixes 1-8 
Appendix 1. Selected well-construction information for sampled wells, Papio-Missouri River Natural Resources District, eastern Nebraska, 1992-2009

The Excel file can be accessed at http://pubs.usgs.gov/sir/2012/5036/downloads/appendix-1.xlsx.

Appendix 2. List of water-quality-related data in tab-delimited data files

The data file can be accessed at http://pubs.usgs.gov/sir/2012/5036/downloads/appendix-2.

Appendix 3. Major ions, nutrients, radionuclides, and trace elements analyzed in groundwater samples, Papio-Missouri River Natural Resources District, eastern Nebraska, 1992-2009

The Excel file can be accessed at http://pubs.usgs.gov/sir/2012/5036/downloads/appendix-3.xlsx.

Appendix 4. Pesticides analyzed in groundwater samples, Papio-Missouri River Natural Resources District, eastern Nebraska, 1992-2009

The Excel file can be accessed at http://pubs.usgs.gov/sir/2012/5036/downloads/appendix-4.xlsx.

Appendix 5. Volatile organic compounds analyzed in groundwater samples, Papio-Missouri River Natural Resources District, eastern Nebraska, 2008-2009

The Excel file can be accessed at http://pubs.usgs.gov/sir/2012/5036/downloads/appendix-5.xlsx.

Appendix 6. Explosive compounds analyzed in groundwater samples, Papio-Missouri River Natural Resources District, eastern Nebraska, 2008-2009

The Excel file can be accessed at http://pubs.usgs.gov/sir/2012/5036/downloads/appendix-6.xlsx.

Appendix 7. Age-dating-related analytes, dissolved gases, and stable isotopes analyzed in groundwater samples, Papio-Missouri River Natural Resources District, eastern Nebraska, 2000-2005

The Excel file can be accessed at http://pubs.usgs.gov/sir/2012/5036/downloads/appendix-7.xlsx.

Appendix 8. Number of samples collected and number of analyses by type of determination for each sampled well, Papio-Missouri River Natural Resources District, eastern Nebraska, 1992-2009

The Excel file can be accessed at http://pubs.usgs.gov/sir/2012/5036/downloads/appendix-8.xlsx. 
Publishing support provided by:

Rolla and West Trenton Publishing Service Centers

For more information concerning this publication, contact: Director, USGS Nebraska Water Science Center 5231 South 19 Street

Lincoln, Nebraska 68512

(402) 328-4100

Or visit the Nebraska Water Science Center Web site at: http://ne.water.usgs.gov/ 



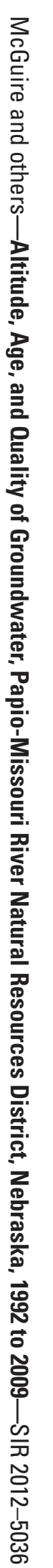

